UNIVERSIDADE DE SÃO PAULO

FACULDADE DE ECONOMIA, ADMINISTRAÇÃO E CONTABILIDADE DEPARTAMENTO DE ECONOMIA

PROGRAMA DE PÓS-GRADUAÇÃO EM ECONOMIA

GESTÃO MUNICIPAL NO PRIMEIRO CICLO DO ENSINO FUNDAMENTAL:

IMPACTOS DA DESCENTRALIZAÇÃO DAS ESCOLAS ESTADUAIS

Vivian de Fátima Amorim

Professora Dra. Fabiana Fontes Rocha

SÃo PAULO 
Prof. Dr. João Grandino Rodas

Reitor da Universidade de São Paulo

Prof. Dr. Reinaldo Guerreiro

Diretor da Faculdade de Economia, Administração e Contabilidade

Prof. Dr. Joaquim José Martins Guilhoto

Chefe do Departamento de Economia

Prof. Dr. Márcio Issao Nakane

Coordenador do Programa de Pós-Graduação em Economia 


\title{
GESTÃO MUNICIPAL NO PRIMEIRO CICLO DO ENSINO FUNDAMENTAL: IMPACTOS DA DESCENTRALIZAÇÃO DAS ESCOLAS ESTADUAIS
}

\begin{abstract}
Dissertação apresentada ao Departamento de Economia da Faculdade de Economia, Administração e Contabilidade da Universidade de São Paulo como requisito para a obtenção do título de Mestre em Ciências.
\end{abstract}

Orientadora: Professora Dra. Fabiana Fontes Rocha

\section{VERSÃO CORRIGIDA}

Versão original está disponível na Faculdade de Economia, Administração e Contabilidade SÃO PAULO 
FICHA CATALOGRÁFICA

Elaborada pela Seção de Processamento Técnico do SBD/FEA/USP

Amorim, Vivian de Fátima

Gestão municipal no primeiro ciclo do ensino fundamental:

impactos da descentralização das escolas estaduais / Vivian de

Fátima Amorim. -- São Paulo, 2013.

$120 \mathrm{p}$.

Dissertação (Mestrado) - Universidade de São Paulo, 2013.

Orientador: Fabiana Fontes Rocha.

1. Educação escolar básica 2. Administração municipal 3. Descentralização administrativa 4. Desigualdades I. Universidade de São Paulo. Faculdade de Economia, Administração e Contabilidade. II. Título.

CDD -370 
Ao meu avô Antônio por ter sido a pessoa mais fofa que eu já conheci 


\section{AGRADECIMENTOS}

Desde criança eu já tinha o sonho de estudar na USP, agradeço aos meus pais e as minhas irmãs por terem acreditado em mim e compartilhado esse sonho comigo até o dia em que ele se realizou. À minha mãe, muito obrigada por ter me dado a oportunidade de estudar. Nós sabemos as dificuldades enfrentadas e eu tenho certeza de que sem ela não teria sido possível.

Às minhas irmãs, muito obrigada pelos abraços mais sinceros. Eu amo muito vocês. Eu sempre fui a caçulinha que vocês defenderam e eu sou muito grata por todo apoio nos momentos em que eu quis desistir.

Aos meus amigos da FEA por terem tornado a jornada mais agradável e menos estressante. À minha turma de mestrado, meu muito obrigada. Vocês são demais e muito especiais. Eu nunca esquecerei todo apoio desde os estudos para Anpec até os dias inteiros que passamos juntos, no primeiro semestre inesquecível de mestrado. Nessa reta final, não tenho nem palavras pra agradecer o apoio da Laura, do Léo, do Rafa, do Dudu e da Eli. Sem vocês, o latex teria travado, o stata não teria rodado e eu não teria conseguido abrir o arcgis.

Às minhas amigas lindas de escola por compreenderem os meus períodos de ausência. No fundo vocês sabiam que eu conseguiria realizar os meus sonhos, mesmo com a minha cabeça dura.

À Fabiana Rocha, muito obrigada pela paciência que teve comigo, desde a escolha do meu tema até as contribuições para este trabalho. Aos professores Naércio Aquino e Ricardo Madeira, obrigada pelas contribuições feitas na banca de qualificação.

Ao professor Fernando Postali, obrigada pela orientação na minha monografia e toda compreensão que teve comigo no meu ano de Anpec.

À FIPE e ao CNPQ pelo apoio financeiro. 
"Anything you want

You got it Anything you need You got it Anything at all You got it" Roy Orbison 


\section{RESUMO}

Este trabalho avalia os efeitos do aumento da proporção de alunos de $1^{a}$ a $4^{a}$ série matriculados em escolas municipais, sobretudo no que concerne à transferência de gestão de algumas escolas estaduais para a administração municipal. Tal processo ocorreu concomitantemente a perda de autonomia fiscal quanto ao direcionamento dos recursos da educação, devido às regras de alocação impostas pelo FUNDEF. Nesse sentido, ainda que a gestão escolar estivesse mais próxima da população, a destinação da maior parte dos recursos ao pagamento de professores em exercício poderia ser contrária às preferências locais. Primeiramente, existem evidências de que o processo de municipalização implicou piora nos indicadores de rendimento, enquanto que as externalidades positivas associadas à alocação de recursos do FUNDEF parecem ter contrabalanceado a perda de autonomia local. Em segundo lugar, existem indicativos de que um componente específico do processo de expansão da gestão municipal, a descentralização das escolas estaduais, esteja associado à queda das taxas de reprovação, após um período de acomodação. Contudo, os resultados sugerem aumento da desigualdade dos resultados educacionais, uma vez que os efeitos positivos concentram-se em municípios com maiores níveis de renda per capita.

Palavras chave: educação escolar básica, administração municipal, descentralização administrativa, desigualdades. 


\begin{abstract}
This work evaluates the effects of increasing the proportion of students from 1st to 4 th grade enrolled in municipal schools, especially regarding the transfer of management of some state schools to the municipalities. This process occurred concurrently with the loss of fiscal autonomy for direction of education resources due to allocation rules imposed by FUNDEF. In this case, even if the school management was closer to the population, the allocation of most resources to pay teachers in practice could be contrary to local preferences. First, there is evidence that increasing the proportion of students from 1st to 4th grade in municipal schools resulted in worsening performance indicators, while positive externalities associated with FUNDEF's resources allocation appear to have counterbalanced the loss of local autonomy. Secondly, there are indications that a specific component of the ongoing expansion of municipal management, decentralization of state schools, is associated with the decrease of failure rates after a period of accommodation. However, the results suggest an increase in inequality of educational outcomes, since the positive effects are concentrated in municipalities with higher levels of income per capita.
\end{abstract}

Keywords: primary school education, municipal administration, administrative decentralization, inequality. 


\section{SUMÁRIO}

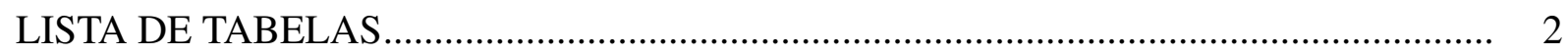

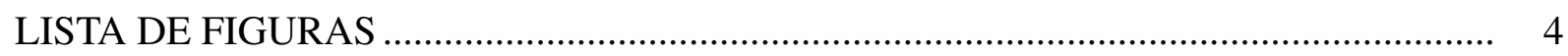

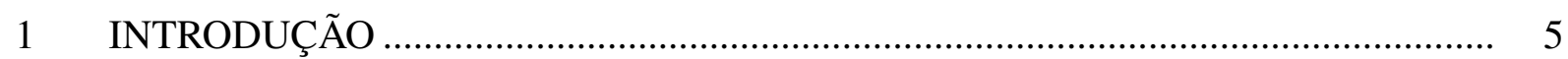

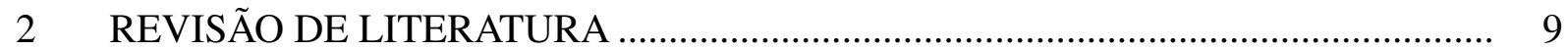

2.1 Municipalização e descentralização no Brasil ........................................................ 12

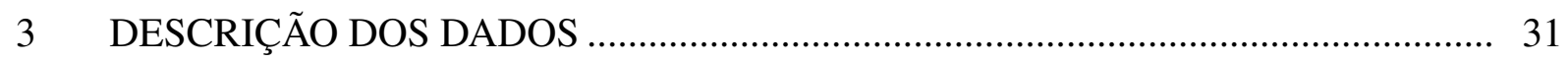

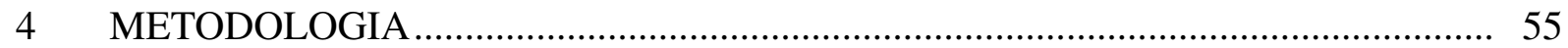

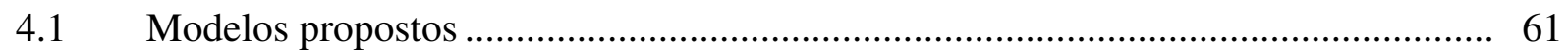

5 RESULTADOS PARA O PAINEL DE MUNICÍPIOS .......................................... 71

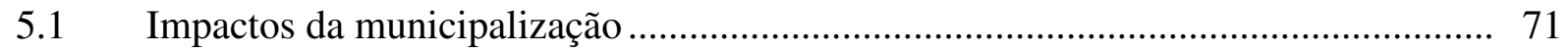

5.2 Diferenças entre os municípios que mais e menos se municipalizaram ................... 74

$6 \quad$ RESULTADOS PARA O PAINEL DE ESCOLAS ….............................................. 77

6.1 Impactos da descentralização das escolas estaduais ............................................. 77

6.2 Interação entre descentralização e renda per capita ............................................... 83

6.3 Interação entre descentralização e Lei de Responsabilidade Fiscal.......................... 85

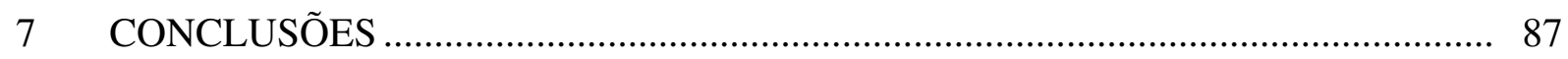

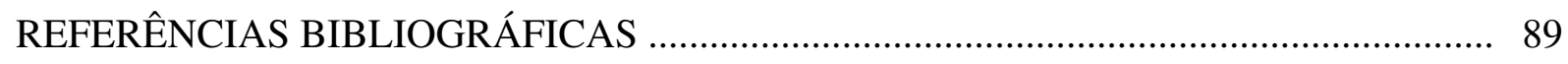

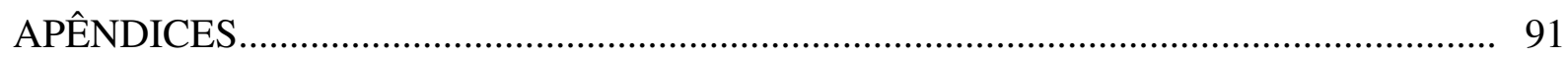

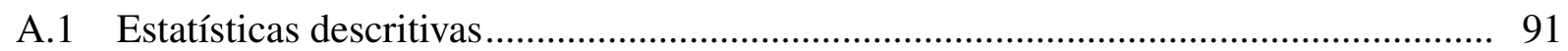

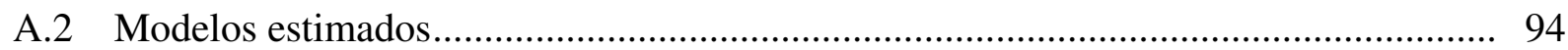




\section{LISTA DE TABELAS}

Tabela 1 - Informações coletadas do Censo Escolar ...................................................... 32

Tabela 2 - Informações coletadas no âmbito dos estados e dos municípios ..................... 35

Tabela 3 - Estatísticas descritivas dos indicadores de rendimento e de distorção idadesérie para alunos de $1^{a}$ a $4^{a}$ série $(1997$ e 2002) ............................................ 37

Tabela 4 - Estatísticas descritivas dos municípios que mais e menos se municipalizaram 48

Tabela 5 - Concentração da descentralização nos estados brasileiros............................... 51

Tabela 6 - Número de escolas estaduais descentralizadas por ano e por estado ............... 52

Tabela 7 - Proporção de municípios e da população estudada por estado para avaliação do impacto da descentralização.................................................................... 53

Tabela 8 - Número de escolas nos grupos de tratamento e comparação por faixa de descentralização

Tabela 9 - Estatísticas descritivas dos grupos de tratamento e comparação antes da descentralização (1997)

Tabela 10 - Impactos da municipalização nos indicadores de rendimento ( $1^{a}$ a $4^{a}$ série $) . .72$

Tabela 11 - Diferenças dos impactos da municipalização entre os municípios que mais e os que menos se municipalizaram $\left(1^{a}\right.$ a $4^{a}$ série $)$

Tabela 12 - Impactos da descentralização das escolas estaduais nos indicadores de rendimento e de distorção idade-série $\left(1^{a}\right.$ a $4^{a}$ série $)$

Tabela 13 - Impactos da descentralização das escolas estaduais nos indicadores de rendimento e de distorção idade-série ( $1^{a}$ série)

Tabela 14 - Interação entre descentralização e renda per capita ( $1^{a}$ a $4^{a}$ série).....

Tabela 15 - Interação entre descentralização e inverso da relação entre gastos com pessoal e Receita Corrente Líquida ( $1^{a}$ a $4^{a}$ série)

Tabela 16 - Estatísticas descritivas dos municípios da amostra (1997 e 2002).....

Tabela 17 - Estatísticas descritivas dos grupos de tratamento e de comparação após a descentralização (2002).

Tabela 18 - Impactos da municipalização por efeitos fixos e por primeiras diferenças $\left(1^{a}\right.$ a $4^{a}$ série) 
Tabela 19 - Impactos da municipalização sem considerar o aumento do número de alunos por escolas $\left(1^{a}\right.$ a $4^{a}$ série $)$

Tabela 20 - Impactos da descentralização por efeitos fixos e por primeiras diferenças ( $1^{a}$ a $4^{a}$ série) - Equação (24)

Tabela 21 - Impactos da descentralização por efeitos fixos e por primeiras diferenças ( $1^{a}$ a $4^{a}$ série) - Equação (26)

Tabela 22 - Impactos da descentralização sem considerar o aumento da matrícula nas escolas dos grupos de tratamento e de comparação ( $1^{a}$ a $4^{a}$ série)

Tabela 23 - Interação entre descentralização e dependência dos recursos do FUNDEF ( $1^{a}$ a $4^{a}$ série)

Tabela 24 - Interação entre descentralização e taxa de abandono ( $1^{a}$ a $4^{a}$ série $)$ 101

Tabela 25 - Interação entre descentralização e o montante de recursos recebidos do FUNDEF $\left(1^{a}\right.$ a $4^{a}$ série $)$.

Tabela 26 - Impactos da descentralização nas taxas de abandono por faixas de descentralização $\left(1^{a}\right.$ a $4^{a}$ série $)$

Tabela 27 - Impactos da descentralização nas taxas de aprovação por faixas de descentralização $\left(1^{a}\right.$ a $4^{a}$ série $)$

Tabela 28 - Impactos da descentralização nas taxas de reprovação por faixas de descentralização ( $1^{a}$ a $4^{a}$ série $)$ 105

Tabela 29 - Impactos da descentralização nas taxas de distorção idade-série por faixas de descentralização ( $1^{a}$ a $4^{a}$ série $)$ 106 


\section{LISTA DE FIGURAS}

Figura 1 - Gasto médio por aluno do ensino fundamental realizado pelos governos municipais (1997 e 2002).

Figura 2 - Proporção de matrículas do ensino fundamental em escolas municipais (1996 a 2002)......

Figura 3 - Ganho líquido dos estados e dos municípios com o FUNDEF (1998) 39

Figura 4 - Ganho líquido dos estados e dos municípios com o FUNDEF (2002) 40

Figura 5 - Relação média entre os recursos do FUNDEF e os gastos com educação e cultura no âmbito dos governos municipais (1998 e 2002).

Figura 6 - Relação média entre os recursos do FUNDEF e os gastos com educação e cultura no âmbito dos governos estaduais (1998 e 2002)

Figura 7 - Proporção de matrículas de $1^{a}$ a $4^{a}$ série em escolas municipais (1997 e 2002) 45

Figura 8 - Indicadores educacionais dos grupos de tratamento e comparação (1996 a 2002) 


\section{INTRODUÇÃO}

A descentralização da prestação de serviços públicos, e em particular da educação, consiste na delegação da responsabilidade de gasto, financiamento e gerenciamento do governo central aos governos locais. Em princípio, aproximar a gestão da população tem o objetivo de adequar a prestação de serviços às preferências de grupos mais homogêneos, o que contribui para a alocação dos recursos conforme as necessidades locais. A literatura teórica pressupõe que os efeitos da descentralização variam de acordo com o contexto do local em que ela foi aplicada e com os indivíduos a ela sujeitos. Dessa forma, é possível inferir impactos positivos para a descentralização ocorrida em níveis de governo com capacitação e habilidade técnica semelhantes à gestão centralizada. Nessas regiões, a existência de uma população mais instruída educacionalmente e, portanto, com maior destreza em fiscalizar e exigir os seus direitos, também corrobora o argumento de que a descentralização pode reduzir a corrupção.

Por outro lado, a descentralização pode implicar piora na prestação de serviços públicos se o governo central, com intuito de reduzir seus problemas fiscais, delegar suas responsabilidades aos governos locais sem lhes proporcionar recursos para tanto. Ademais, ainda que a descentralização ocorra simultaneamente ao aumento da capacidade de gasto, o governo local pode apresentar menor habilidade quanto à aplicação eficiente dos recursos. Essa ameaça existe majoritariamente em regiões mais pobres, nas quais o governo pode atuar em detrimento da população mais carente, principalmente devido à sua menor instrução política e educacional.

No Brasil, o impulso para a descentralização do ensino fundamental ocorreu após a implantação do Fundo de Manutenção e Desenvolvimento do Ensino Fundamental (FUNDEF) em 1998. Com o objetivo de adequar o financiamento da educação ao número de alunos das redes estadual e municipal, o Fundo vinculou a disponibilização de recursos ao total de matrículas. De tal modo, aumentaram-se os incentivos para que os municípios absorvessem maior proporção de alunos de $1^{a}$ a $4^{a}$ série. Simultaneamente a expansão da gestão municipal, ocorreu o declínio da autonomia de gasto, devido às regras impostas pelo FUNDEF quanto à alocação dos recursos. Embora exista a possibilidade de as imposições terem sido contrárias às preferências locais, o repasse de verbas diretamente aos departamentos de educação, os mecanismos fortalecidos de controle social e a alocação de recursos com professores em efetivo exercício constituem externalidades positivas associadas a esse novo mecanismo.

O FUNDEF possuía uma evidente característica equalizadora que contribuiu para a redução das 
discrepâncias dos gastos com educação. Por outro lado, existem evidências de que o processo de municipalização não constituiu uma transferência organizada de alunos entre as redes de ensino. Para o primeiro ciclo do ensino fundamental, por exemplo, o aumento do tamanho médio das escolas municipais é o fator que mais explica o aumento da proporção de alunos de $1^{a}$ a $4^{a}$ série matriculados em escolas municipais. Além disso, os municípios, nos quais o aumento da matrícula municipal foi mais intenso, eram os que apresentavam menor proporção de matrículas de $1^{a}$ a $4^{a}$ série, o que evidencia a falta de experiência com a gestão do ensino fundamental.

Um componente específico do processo de municipalização, a descentralização de algumas escolas estaduais, é o segundo fator que mais explica o aumento da proporção de alunos de $1^{a}$ a $4^{a}$ série matriculados em escolas municipais. Embora a proporção de municípios por estado que descentralizaram escolas estaduais seja baixa, existe um número elevado de escolas descentralizadas entre 1998 e 2002, o que possibilita o estudo, por meio da metodologia de diferença em diferenças, dos impactos da gestão municipal comparativamente às escolas que permaneceram sob gestão estadual.

Primeiramente, por meio da constituição de um painel de municípios entre os anos de 1997 e 2002, este trabalho avalia os impactos da migração de rede, aumento da proporção de alunos de $1^{a}$ a $4^{a}$ série matriculados em escolas municipais, e da expansão de rede, aumento da proporção de escolas de $1^{a}$ a $4^{a}$ série no total de escolas, nos indicadores de rendimento e de distorção idade-série. Diferentemente da maior parte dos trabalhos já realizados, procura-se separar os impactos da expansão da gestão municipal e da menor autonomia de gasto imposta aos estados e municípios. Para tanto, emprega-se um indicador de dependência fiscal obtido por meio da relação entre os recursos advindos do FUNDEF e os gastos realizados com educação e cultura.

Em segundo lugar, por meio de um painel de escolas entre 1997 e 2002, avalia-se o impacto da troca de gestão de algumas escolas estaduais para a administração municipal nos indicadores de rendimento e de distorção idade-série auferidos por alunos de $1^{a}$ a $4^{a}$ série. Incluem-se na análise uma série de variáveis no âmbito dos estabelecimentos de ensino e dos municípios em que eles estão localizados. Nesse sentido, ressalta-se que a menor autonomia de gasto também foi imposta aos governos estaduais. Dessa forma, considera-se o indicador de dependência fiscal no âmbito dos municípios, para as escolas descentralizadas, e no âmbito dos estados, para as escolas que permaneceram sob gestão estadual. O objetivo é controlar a maior parte das diferenças entre os dois grupos, de modo a obter um estimador consistente para o impacto da descentralização. 
Este trabalho está dividido em sete seções. A Seção 2 apresenta a revisão de literatura acerca descentralização da educação e, especificamente, da municipalização observada no final da década de 90. A Seção 3 contém a descrição da base de dados utilizada. A Seção 4 descreve a metodologia adotada. A Seção 5 apresenta os resultados para o painel de municípios. A Seção 6 apresenta os resultados para o painel de escolas. Por fim, a Seção 7 sintetiza as principais conclusões. 


\section{REVISÃO DE LITERATURA}

A descentralização, entendida como a transferência de responsabilidade de gasto, financiamento e gerenciamento para os governos locais, pode ser vista como uma das políticas mais prescritas para melhorar a provisão de serviços públicos. Tanto é verdade que Manor (1999) estima que já no final dos anos 1990, oitenta por cento dos países tinham adotado alguma forma de descentralização. O interesse nessa inovação institucional cresceu especialmente nos países em desenvolvimento, por representar uma possível alternativa contra governos ineficientes, instabilidade macroeconômica e baixo crescimento econômico (BIRD; VAILLANCOURT, 2008).

$\mathrm{Na}$ literatura teórica favorável a essa política, citam-se os argumentos que a descentralização pode implicar alocação mais eficiente de recursos do setor público. Primeiramente, decisões centralizadas não consideram diferenças entre indivíduos, assim ao adequar os níveis de consumo às preferências de grupos mais homogêneos, a descentralização de serviços públicos tem capacidade de aumentar o bem estar econômico. Em segundo lugar, se um país conta com gestões descentralizadas existe uma competição política entre os governos locais responsável por gerar limitações ao crescimento orçamentário, aumentar a pressão pela disponibilização eficiente de serviços públicos e, em um contexto de mobilidade familiar, permitir que os indivíduos busquem a gestão descentralizada que forneça serviços que melhor atendam às suas preferências. Ademais, a descentralização pode promover inovação e maior conhecimento em relação aos serviços oferecidos para a sociedade (WALLIS; OATES, 1988).

Para Bardhan e Mookherjee (2005), a descentralização pode implicar queda da corrupção, na medida em que é mais fácil para os cidadãos monitorarem o desempenho de governos locais, comparativamente à gestão de um sistema centralizado. No entanto, esse argumento está baseado na hipótese de que a democracia funciona efetivamente e pressupõe um nível de consciência política e alfabetização da população que pode ser irrealista em muitos países em desenvolvimento. Dessa forma, os governos locais podem ser capturados por "elites" que impeçam a realização de muitas políticas públicas, além de desviarem recursos para projetos que os favoreçam, em detrimento da população mais pobre. Essa ameaça existe sobretudo em regiões com maiores índices de pobreza, nas quais a menor instrução educacional da população está refletida na menor destreza em fiscalizar seus direitos.

Ainda nesse sentido, a descentralização pode apresentar efeitos perversos se os governos locais estiverem aquém da habilidade técnica e capacitação institucional do governo central (SMITH, 
1985). Nesses casos, a descentralização representaria abandono de algumas regiões dado que, até então, a gestão centralizada garantia pelo menos um nível mínimo de prestação de serviços públicos. O governo central pode ainda, com intuito de reduzir seus problemas fiscais, delegar suas responsabilidades aos governos locais sem, contudo, lhes proporcionar recursos para tanto, o que implicaria piora no bem estar dos indivíduos sobretudo devido à falta de investimentos.

Nesse contexto, os trabalhos teóricos em relação à descentralização sugerem que ela pode representar tanto o instrumento responsável pelo arrefecimento dos problemas enfrentados pelos países em desenvolvimento, quanto o propulsor do agravamento das dificuldades já existentes. Espera-se que o impacto da descentralização varie de acordo com o contexto do local em que foi aplicada e com os indivíduos a ela sujeitos. Dessa forma, pressupõem-se efeitos benéficos em áreas bem administradas por governos locais e nas quais os moradores apresentem maior instrução política para fiscalizar e exigir seus direitos. Por outro lado, em regiões mal administradas e com população menos instruída, podem-se inferir impactos negativos para a descentralização. Consequentemente, uma implicação da literatura teórica é que a descentralização pode levar ao aumento da desigualdade existente, por exemplo, entre municípios de um mesmo estado (GALIANI; GERTLER; SCHARGRODSKY, 2008).

A literatura empírica, assim como a teórica, não é consensual. Channa e Faguet (2012) realizam uma revisão cuidadosa da literatura aplicada sobre os impactos, nos países em desenvolvimento, decorrentes da descentralização da prestação de serviços públicos. Inicialmente, os autores classificam os trabalhos realizados em dois grupos, de acordo com seus objetivos. O primeiro grupo é o de matching de preferências, em que se busca mensurar a extensão pela qual a prestação de serviços públicos pelos governos locais atende melhor as preferências (demandas) dos residentes. O segundo grupo é o da eficiência técnica, em que se procura avaliar a disponibilização de um ou mais serviços públicos de forma descentralizada dado um conjunto de insumos ${ }^{1}$. Em seguida, os autores agrupam os trabalhos realizados em quatro categorias, conforme a qualidade e a credibilidade das estratégias de identificação adotadas: altamente crível (very strongly credible), fortemente crível (strongly credible), em alguma medida crível (somewhat credible) e menos crível (less credible).

No grupo de eficiência técnica, no que concerne à descentralização da educação e no qual o presente trabalho se enquadra, nenhum estudo obteve a classificação de altamente crível e so-

\footnotetext{
${ }^{1}$ Os estudos neste segundo grupo são separados de acordo com as áreas avaliadas: saúde e educação providas pelos governos locais e school-based management (SBM) reform.
} 
mente dois trabalhos foram considerados de alta qualidade ${ }^{2}$. O trabalho de Galiani, Gertler e Schargrodsky (2008) é um deles. Os autores avaliam o impacto da descentralização das escolas federais argentinas sobre os exames de proficiência em matemática e espanhol e concluem que, em média, os efeitos foram positivos e significativos. Encontram, contudo, evidência de que houve aumento na desigualdade dos resultados educacionais, uma vez que o efeito é negativo em províncias pobres e mal administradas ${ }^{3}$ e positivo em províncias ricas e bem administradas.

Outro trabalho classificado como altamente crível é o de Faguet e Sanchez (2008). Os autores procuram medir o impacto da descentralização das escolas estaduais da Colômbia e da Bolívia sobre as mudanças nas taxas de matrículas desses países. Concluem que, em média, a descentralização apresentou impactos positivos nos resultados educacionais, ao encontrarem indícios de que parte dos investimentos em infraestrutura e indústria foram redirecionados para educação, água e saneamento básico. No primeiro país, houve aumento das taxas de matrícula nas escolas públicas, o que sugere que a descentralização, de médio a longo prazo, contribuirá para o aumento das taxas de alfabetismo. Já no segundo, os investimentos passaram a ser direcionados para as áreas com as maiores deficiências educacionais. Além disso, em ambos os países, foi o comportamento de municípios menores, mais pobres e mais rurais que conduziram essas mudanças.

Rodriguez (2006) avalia o impacto da descentralização na qualidade das escolas públicas colombianas. A autora compara a evolução dos indicadores de proficiência dessas escolas com os obtidos pelas escolas privadas. Ocorre que nesse período a descentralização está relacionada ao aumento significativo do volume de matrículas em escolas públicas, decorrente da queda da evasão escolar. Ao assumir que na ausência dessa política muitos alunos que deixariam a escola são os menos habilidosos, e ao levar em consideração o seu desempenho mais baixo, a metodologia de diferença em diferenças fornece evidências de efeitos positivos da descentralização: o sistema público melhorou sua qualidade e recebeu mais alunos. Sem essa consideração, o efeito da política seria confundido com o desempenho mais baixo de alunos que só permaneceram na escola devido à descentralização.

\footnotetext{
${ }^{2}$ No que concerne à educação, o maior grupo é o em alguma medida crível. Nesse grupo estão incluídos Aslam e Yilmaz (2011) e Freinkman e Plekhanov (2009), que encontram evidência positiva da descentralização, e Inchaute (2009) que conclui que o efeito da descentralização é limitado.

${ }^{3}$ Em relação à qualidade do governo local, os autores utilizaram duas medidas. Primeiramente, classificou as províncias como fiscalmente irresponsáveis caso tivessem apresentado, em média, déficit fiscal maior (em valor absoluto) que $1.35 \%$ nos três anos anteriores a política. Como segundo indicador, os autores utilizaram um índice desenvolvido por Jones, Sanguinetti e Tommasi (2000), referente à qualidade das instituições orçamentárias das províncias.
} 
Barankay e Lockwood (2007) encontram uma associação positiva entre a descentralização fiscal e a eficiência na disponibilização de educação na Suíça. Semelhantemente ao encontrado por Galiani, Gertler e Schargrodsky (2008), os autores mostram que a descentralização aumentou a proporção de jovens de 19 anos que obtém o Maturité 4 e que os efeitos se potencializam quanto maior for a capacitação do governo local. Os resultados também sugerem que os efeitos positivos da descentralização são mais intensos nos homens, o que contribuiu para redução da diferença entre homens e mulheres contemplados com o certificado ${ }^{5}$.

\subsection{Municipalização e descentralização no Brasil}

A Educação Básica no Brasil é composta por três etapas: Educação Infantil (creche e préescola), Ensino Fundamental ${ }^{6}$ (de $1^{a}$ a $8^{a}$ série) e Ensino Médio (do $1^{o}$ ao $3^{o}$ ano), e quatro modalidades: Ensino Regular, Educação Especial, Educação Profissional e Educação de Jovens e Adultos. A disponibilização da Educação Básica ocorre em escolas públicas, federais, estaduais e municipais, e em escolas privadas. De acordo com dados do Instituto Nacional de Estudos e Pesquisas Educacionais (INEP), entre 1996 e 2002, aproximadamente $90 \%$ dos alunos do ensino fundamental estavam matriculados em escolas públicas, o que revela a dimensão do ensino público brasileiro e a importância do estudo de políticas que o afete diretamente.

No início da década de 90, muitas crianças de 7 a 14 anos ainda estavam fora da escola e as taxas de abandono e reprovação eram muito elevadas, o que sugere que os sistemas escolares careciam de incentivos que mantivessem as crianças na escola e de políticas que estimulassem o aprendizado. As altas taxas de repetência estavam associadas a maior proporção de crianças alocadas no período não ideal para sua idade o que, por sua vez, aumentava a probabilidade de evasão. Além disso, a baixa qualidade do ensino implicava aumento do custo de oportunidade em permanecer na escola. Os recursos para educação não eram alocados conforme as necessidades educacionais e não forneciam incentivos para resolver os problemas de acesso, qualidade e equidade. A disparidade dos serviços educacionais oferecidos dentro de um mesmo estado e entre estados da Federação repercutiam na desigualdade dos padrões de vida (BANCO MUNDIAL, 2002).

\footnotetext{
${ }^{4}$ Certificado que permite o ingresso na faculdade.

${ }^{5}$ Até a descentralização ocorrer, eram as mulheres que mais recebiam o certificado.

${ }^{6}$ A Lei $n^{o} 11.274$ de 6 de fevereiro de 2006 alterou a Lei de Diretrizes e Bases da Educação ao ampliar a duração do ensino fundamental para 9 anos, com matrícula obrigatória a partir dos 6 anos de idade. A Lei estabeleceu que os estados e municípios deveriam se adaptar ao novo regimento até final de 2010.
} 
Ainda nas décadas de 70 e 80 algumas iniciativas, sobretudo no Nordeste, foram realizadas com intuito de transferir a gestão do ensino fundamental para os municípios, tendo em vista ampliar o acesso e melhorar a qualidade da educação oferecida. A princípio, tornar o ensino fundamental uma responsabilidade das prefeituras, e não mais do governo estadual, tem por objetivo aumentar a participação dos cidadãos na elaboração, implantação e avaliação do processo de ensino-aprendizagem, o que contribui com a maior agilidade na gestão de políticas públicas. A descentralização também pode facilitar a articulação de programas e aumentar a eficácia dos mecanismos de controle e alocação de recursos (RAZO, 2004).

Nesse contexto, define-se municipalização como a transferência de atividades educacionais dos estados para os municípios, de forma que tal processo pode ser entendido como o aumento da proporção de alunos $^{7}$ do ensino público matriculados em escolas municipais ${ }^{8}$. No entanto, a definição de escolas estaduais e municipais não é trivial devido à diferença de arranjos administrativos com relação a quem detém o prédio escolar, quem nomeia o diretor e quem paga os professores e as despesas operacionais. Dessa forma, de acordo com o Ministério da Educação, uma escola é estadual caso seu diretor seja nomeado pelo governador ou secretário estadual da educação e é municipal se o diretor for nomeado pelo prefeito ou secretário municipal.

Embora seja consenso que a maior parte do desempenho educacional dos alunos esteja associada às características familiares, especialmente educação dos pais, também se deve considerar a importância de recursos econômicos e fatores institucionais. O número médio de alunos por turma, a jornada escolar, o acesso a livros, à biblioteca, a computadores, a métodos adequados de ensino e a melhor qualificação dos professores, por exemplo, também explicam parte do desempenho dos alunos e estão diretamente relacionados à gestão escolar (LEME; PAREDES; SOUZA, 2009). Consequentemente, políticas educacionais constituem o instrumento direto para modificar a qualidade do ensino e elevar os níveis médios de aprendizado, o que perpetua os seus efeitos positivos, na medida em que pais com maior escolaridade estimulam o nível educacional atingido pelos seus filhos.

A municipalização passou a ser discutida na década de 50 pelo jurista e educador Anísio Teixeira, ao afirmar que tal processo consistia em uma estratégia de expansão para o ensino fundamental. Contudo, foi apenas com a Constituição de 1988, embora o termo municipalização não

\footnotetext{
${ }^{7}$ Considera-se o total de alunos matriculados no ensino fundamental público a soma dos alunos de escolas estaduais e municipais. O total de alunos matriculados em escolas federais é residual.

${ }^{8}$ Essa definição não é consensual. Para alguns autores, a municipalização representa apenas a transferência de escolas de uma rede para outra (SOARES; SOUZA, 2003).
} 
apareça explicitamente, que se estabeleceu que os municípios deveriam atuar prioritariamente na pré-escola e no ensino fundamental ${ }^{9}$ e os estados no ensino fundamental e médio. Além disso, determinou-se que $25 \%$ do total das receitas dos estados e municípios e $18 \%$ das receitas da União deveriam ser destinados aos gastos com educação. Entretanto, não foram estabelecidos incentivos, nem proporcionados recursos adicionais para que os municípios pudessem assumir um maior contingente de alunos do ensino fundamental e, ainda que a Constituição tenha vinculado parte dos recursos já existentes aos gastos com educação, não existiam regras específicas para a destinação de tais recursos, tampouco fiscalização.

Dessa forma, muitos municípios investiram em atividades pouco relacionadas à educação ${ }^{10} \mathrm{e}$ houve aumento da heterogeneidade entre as escolas públicas de municípios ricos e pobres. Enquanto os primeiros, embora com menor proporção de alunos matriculados em escolas públicas, apresentavam maior montante de recursos para serem despendidos em educação, municípios pobres e com maior proporção de alunos na rede pública, careciam de recursos (MENEZES-FILHO et al., 2008). Essa desigualdade refletia diretamente nos indicadores de rendimento (taxas de aprovação, reprovação e abandono) e de distorção idade-série ${ }^{11}$.

As discrepâncias não se restringiam às escolas públicas de municípios ricos e pobres. Eram elevadas as diferenças entre escolas administradas pelos estados e as pelos seus respectivos municípios. Os sistemas estaduais eram enormes comparativamente aos municipais e, ao contar com maior montante de recursos e com maior capacitação das Secretarias Estaduais de Educação, as escolas estaduais apresentavam maior proporção de insumos e indicadores educacionais mais elevados, o que evidencia a falta de cooperação entre estados e municípios quanto à equidade na disponibilização da educação pública.

Em 1996, quase 10 anos após a promulgação da Constituição, a aprovação da Lei de Diretrizes e Bases da Educação (Lei 9.394) estabeleceu os papéis e as responsabilidades da União, dos estados e dos municípios no tocante à gestão da área de educação, às obrigações das instituições de ensino, à carga horária mínima, às diretrizes curriculares básicas e às funções e obrigações dos profissionais de educação. O INEP ficou responsável pela criação e produção de estatísticas educacionais e pela avaliação dos alunos.

\footnotetext{
${ }^{9} \mathrm{~A}$ emenda constitucional $n^{o} 14$ alterou o texto para: os municípios atuarão prioritariamente no ensino fundamental e na educação infantil.

${ }^{10}$ Pavimentação de ruas próximas às escolas, por exemplo.

${ }^{11}$ Esse indicador permite avaliar a proporção de alunos, em cada série, com idade superior à recomendada.
} 
Cabe à União, coordenar a Política Nacional de Educação, articular os níveis e sistemas de ensino e exercer funções normativas, redistributivas e supletivas em relação às demais instâncias educacionais. Deve estabelecer, em colaboração com os estados, os municípios e o Distrito Federal, competências e diretrizes para a educação infantil e para o ensino fundamental e médio. Dessa forma, ficam estabelecidos conteúdos mínimos, o que contribui para assegurar formação básica comum. A União também é responsável por prestar assistência técnica aos entes federativos para o desenvolvimento de seus sistemas de ensino e para o atendimento prioritário à escolaridade obrigatória.

Os estados são responsáveis por elaborar, manter e desenvolver seu sistemas de ensino, preparar e executar políticas educacionais e definir, conjuntamente com os municípios, formas de colaboração para oferta do ensino fundamental. Essa colaboração, por sua vez, deve assegurar a distribuição proporcional das responsabilidades, de acordo com a população a ser atendida e os recursos financeiros disponíveis em cada uma das esferas do poder público.

A Lei definiu os municípios como entes federativos autônomos, tanto no que concerne à formulação quanto à gestão da política pública educacional. Os municípios podem administrar as suas escolas e definir normas e metodologias que mais se adaptem às suas peculiaridades. Nesse sentido, dentre outras atribuições, cabe a essa esfera de governo, o desenvolvimento de seus sistemas de ensino, integrando-os aos planos educacionais da União e dos estados, a execução de ações redistributivas com relação às suas escolas e o estabelecimento de normas complementares.

No entanto, a LDB não resolveu os problemas relativos ao financiamento do ensino fundamental e, embora tenha estabelecido que estados e municípios deveriam atuar conjuntamente para disponibilização desse nível de ensino, não criou mecanismos que incentivassem a cooperação entre essas esferas de governo. Ainda em 1996, a alteração da estrutura de financiamento do ensino fundamental ocorreu com a criação do Fundo de Manutenção e Desenvolvimento do Ensino Fundamental (FUNDEF), por meio da Emenda Constitucional $n^{o} 14$ e sua posterior regulamentação pela Lei $n^{\circ} 9.424$.

O Fundo determinou a vinculação dos recursos da educação a esse nível de ensino, com o objetivo de adequar o investimento ao número de alunos matriculados, garantir a universalização e melhorar a qualidade da educação oferecida. Para tanto, os focos principais consistiam no 
aumento da remuneração dos profissionais do magistério e no estabelecimento de um valor mínimo a ser gasto por aluno. Ao vincular a disponibilização de recursos ao número de alunos matriculados, o Fundo representou o impulso decisivo para o aumento da proporção de alunos do ensino fundamental matriculados em escolas municipais.

Sua implantação ocorreu em janeiro de 1998 em todo país. O Fundo era composto especialmente por recursos próprios dos estados e municípios. O Fundo era constituído de $15 \%$ do:

- Fundo de Participação dos Estados;

- Fundo de Participação dos Municípios;

- Imposto sobre Circulação de Mercadorias e Serviços - ICMS (inclui os recursos relativos à desoneração de exportações, de que trata a Lei Complementar $n^{\circ} 87 / 96$ ); e

- Imposto sobre Produtos Industrializados, proporcional às exportações - IPIexp.

Inicialmente tais recursos eram redirecionados a um fundo comum de cada estado e posteriormente redistribuídos entre o estado e seus municípios de acordo com o número de alunos matriculados no ensino fundamental regular ${ }^{12}$ de suas respectivas redes, com base nos dados do Censo Escolar do ano anterior. A título de complementação, caso o total dos recursos não fosse suficiente para estabelecer um valor mínimo a ser gasto por aluno ${ }^{13}$, uma parcela adicional seria recebida da União. Determinou-se que $60 \%$ do montante total recebido deveria ser direcionado para o pagamento de professores em efetivo exercício e profissionais de suporte pedagógico ${ }^{14}$. Os 40\% restantes deveriam ser aplicados na manutenção e no desenvolvimento do ensino, o que, conforme estabelecido na Lei de Diretrizes e Bases da Educação, compreende, entre outros, os gastos com aquisição e manutenção de equipamentos necessários ao ensino, a aquisição de material didático, a realização de estudos e pesquisas, de modo a aprimorar a qualidade da educação, garantir a expansão do ensino e a habilitar professores leigos ${ }^{15}$.

Após a implantação do FUNDEF, observa-se o aumento do número de professores em atividade

\footnotetext{
${ }^{12}$ A partir de 2000, os recursos passaram a ser redistribuídos de acordo com o total de matrículas do ensino fundamental, tanto educação regular quanto educação especial.

${ }^{13}$ A partir de 2000 , foram estabelecidos valores mínimos diferentes por aluno. O gasto per capita realizado com alunos de $5^{a}$ a $8^{a}$ série e com alunos de educação especial deveria ser $5 \%$ superior do que o despendido com alunos de $1^{a}$ a $4^{a}$ série.

${ }^{14}$ Tais como profissionais em efetivo exercício em uma ou mais escolas da respectiva rede de ensino, alocados na direção ou na administração escolar, no planejamento, na inspeção, na supervisão e na orientação educacional.

${ }^{15}$ Professores com nível de formação até o ensino fundamental ou médio.
} 
e a elevação de suas qualificações ${ }^{16}$. O número de docentes das escolas municipais de ensino fundamental passou de aproximadamente $600.000 \mathrm{em} 1997$ para $750.000 \mathrm{em} \mathrm{2000.} \mathrm{Esse} \mathrm{au-}$ mento, combinado com a elevação da remuneração, implicou variação de $42 \%$ da folha salarial. Entre 1997 e 2002, concomitante à redução de 47\% de professores com nível de formação fundamental foi o aumento da proporção de graduados em $25 \%$ e a proporção de pós-graduados em 140\% (BANCO MUNDIAL, 2002).

Simultaneamente, para todas as regiões, observa-se estreitamento da diferença salarial entre professores da rede estadual e municipal e o aumento da média salarial. Ressalta-se a experiência do Nordeste, em que brecha salarial entre professores das redes estadual e municipal, com nível de qualificação de ensino médio, passou de 53\% em 1997 para 19\% em 2000. Embora a desigualdade salarial entre as regiões tenha permanecido elevada, como a diferença de $1 / 3$ entre o salário pago a professores da rede municipal do Nordeste e do Sudeste, em parte devido às diferenças no custo de vida, a elevação do salário médio dos professores contribuiu para o aumento da atratividade da profissão do magistério (BANCO MUNDIAL, 2002).

Quanto à estrutura de financiamento do ensino fundamental, o mecanismo de funcionamento do FUNDEF possuía uma característica equalizadora que contribuiu para diminuição das discrepâncias dos gastos com educação. Ao determinar a alocação de recursos conforme o número de alunos matriculados no ensino fundamental, o Fundo garantiu a redistribuição de recursos entre municípios de um mesmo estado e entre determinado estado e seus municípios.

Como as transferências dentro de cada estado deveriam apresentar soma zero, a não ser que tivessem sido recebidos recursos complementares da União, municípios mais ricos e com menor proporção de alunos matriculados no ensino fundamental contribuíram mais do que arrecadaram com o Fundo. O oposto ocorreu com os municípios mais pobres e com maior proporção de alunos. A redistribuição de recursos também ocorreu entre as esferas estadual e municipal, a depender da relação de alunos matriculados nas redes de ensino, de forma que os estados, assim como os municípios, podem ser beneficiários líquidos de recursos para o FUNDEF.

A Figura 1 apresenta o gasto médio por aluno do ensino fundamental realizado pelos governos

\footnotetext{
${ }^{16}$ A LDB estabelece que os docentes da educação básica deverão ser formados em nível superior (licenciatura plena). Entretanto, admite como formação mínima a de nível médio para o exercício da docência na educação infantil e nas quatro primeiras séries do ensino fundamental. Não foi estabelecido um prazo para os sistemas deixarem de aceitar a formação em nível médio para quem faz parte do quadro do magistério com atuação nas quatro primeiras séries do ensino fundamental.
} 
municipais ${ }^{17}$ em 1997 e em 2002. Embora a desigualdade quanto ao montante alocado com educação ainda seja evidente, é clara a evolução do nível de gasto dos governos municipais. Para todas as regiões, a relação entre o $95^{\circ}$ e $5^{\circ}$ percentil da distribuição de gasto por aluno diminuiu, o que sugere queda na desigualdade. Ou seja, o mecanismo de redistribuição de recursos do FUNDEF de fato contribuiu para redução das disparidades entre municípios ricos e pobres.

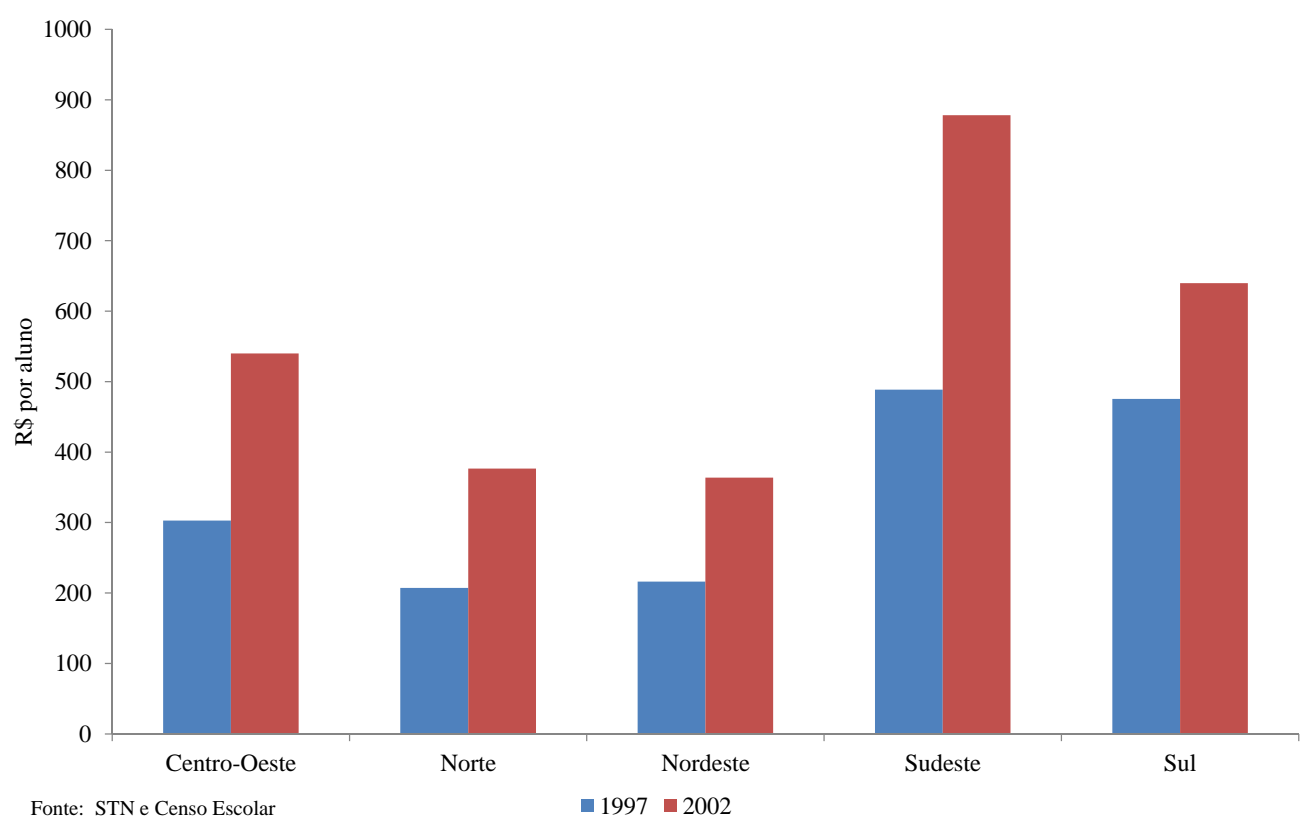

Figura 1: Gasto médio por aluno do ensino fundamental realizado pelos governos municipais (1997 e 2002)

\footnotetext{
${ }^{17}$ Para obtenção do gasto por aluno, adotou-se o critério de que a proporção dos gastos com educação e cultura alocados com o ensino fundamental é igual a relação entre as matrículas municipais e a matrícula total do município $\left(1^{a}\right.$ a $8^{a}$ série). A mesma metodologia foi adotada no estudo sobre educação municipal no Brasil realizado pelo Banco Mundial (2002). Define-se 1997 como o ano base e o gasto com educação e cultura dos governos municipais em 2002 foi deflacionado pelo IGP.
} 
Também é importante ressaltar as transferências realizadas no âmbito dos governos estaduais e municipais, devido à histórica discrepância de gasto entre essas esferas de governo, até então, refletidas em indicadores educacionais mais elevados para as escolas estaduais. A análise da correlação entre as transferências efetuadas e a brecha existente entre as esferas estadual e municipal antes da vigência do Fundo, no que concerne ao gasto por aluno e à remuneração dos professores, fornece indicativos de que os estados que transferiram relativamente mais recursos para os municípios foram aqueles cuja desigualdade existente anteriormente era mais elevada (BANCO MUNDIAL, 2002).

Percebe-se, assim, que diferentemente da Constituição de 1988 e da Lei de Diretrizes e Bases da Educação, o FUNDEF conseguiu estimular a cooperação entre os governos estaduais e municipais pela partilha equitativa de recursos. Ainda que existam evidências de que municípios mais ricos tenham ficado mais ricos, de forma que não tenha havido convergência entre os municípios com relação à receita municipal total, o padrão das transferências mudou. Os municípios que recebiam maior montante de transferências em 1996 não são os mesmos em 2000. Ademais, o padrão dos gastos com educação não seguiu o mesmo padrão das despesas totais. Apesar de os municípios com maiores níveis de dispêndio tenham permanecido os mesmos, os municípios que gastavam pouco com educação não mantiveram seus gastos baixos, pelo menos em termos relativos (BANCO MUNDIAL, 2002).

Quanto às regras de alocação dos recursos advindos do FUNDEF, ao determinar que $60 \%$ deles deveriam ser destinados ao pagamento de professores ${ }^{18}$ em efetivo exercício e atividades correlatas, o Fundo impôs maior rigidez de gastos aos estados e municípios. Ainda que a Constituição de 1988 tenha alocado uma proporção fixa das receitas aos gastos com educação, os entes federativos poderiam empregar os recursos como desejassem. Contudo, embora o FUNDEF tenha implicado declínio da autonomia de gasto, o repasse de recursos diretamente aos departamentos de educação, os mecanismos fortalecidos de controle social e a alocação de recursos para professores ativos constituem externalidades positivas associadas a esse novo mecanismo.

O fato de os recursos do FUNDEF não poderem ser destinados ao pagamento de pensões para professores aposentados constitui um exemplo interessante de como restrições impostas pelo Governo Federal, sobre os gastos locais, podem ser benéficas aos estudantes. Embora a LDB

\footnotetext{
${ }^{18}$ A Lei também estabeleceu que até dezembro de 2001, os estados e municípios que apresentavam professores com níveis muito baixos de qualificação poderiam alocar parte dos $60 \%$ dos recursos do Fundo com o treinamento de professores.
} 
tenha estabelecido diretrizes claras a respeito do que pode ser considerado despesas educacionais, o que contribui para evitar desperdício de recursos públicos, o pagamento de pensão para professores aposentados ainda não havia sido resolvido (BANCO MUNDIAL, 2002).

Para a fiscalização da alocação dos recursos advindos do FUNDEF foram estabelecidos Conselhos de Acompanhamento e Controle Social. Os Conselhos deveriam ser compostos por, no mínimo, 4 membros que representavam os seguintes segmentos:

- a Secretaria Municipal de Educação (ou órgão equivalente);

- os professores ou diretores das escolas públicas de ensino fundamental;

- os pais de alunos; e

- os servidores das escolas públicas de ensino fundamental.

Existem evidências do papel efetivo desses Conselhos na garantia do uso adequado dos recursos públicos. No entanto, ainda é grande o debate acerca da eficácia de mecanismos de controle social $^{19}$. Ressaltam-se os efeitos perversos da descentralização em níveis de governo com menor capacitação institucional que a gestão central. Nesses casos, os Conselhos formados nunca se reuniram e coube apenas ao prefeito a alocação dos recursos disponíveis (BANCO MUNDIAL, 2002).

Por fim, o FUNDEF proporcionou as condições para que os municípios absorvessem os alunos de $1^{a}$ a $8^{a}$ série, mas não os obrigou a isso. De qualquer forma, é claro o avanço da proporção de alunos do ensino fundamental matriculados em escolas municipais, como pode ser observado na Figura 2.

\footnotetext{
${ }^{19}$ Em julho de 2013, o Relatório de Avaliação da Execução de Programas de Governo (AEPG) do Fundo de Manutenção e Desenvolvimento da Educação Básica (FUNDEB), elaborado pela Controladoria Geral da União (CGU), revela que, nos quatro estados e 120 municípios fiscalizados na amostra, foram detectados casos de professores cujos salários eram menores do que o piso nacional e, em vários municípios, foram verificadas despesas incompatíveis com o objetivo do FUNDEB, além de irregularidades em licitações. Ainda que na maioria dos estados e municípios fiscalizados, os respectivos Conselhos de Acompanhamento e Controle Social encontrem-se estruturados, eles apresentam fragilidades no acompanhamento da execução dos recursos do Fundo e na supervisão da realização do Censo Escolar. Disponível em <http://www.cgu.gov.br/Imprensa/Noticias/2013/noticia08813.asp>.
} 


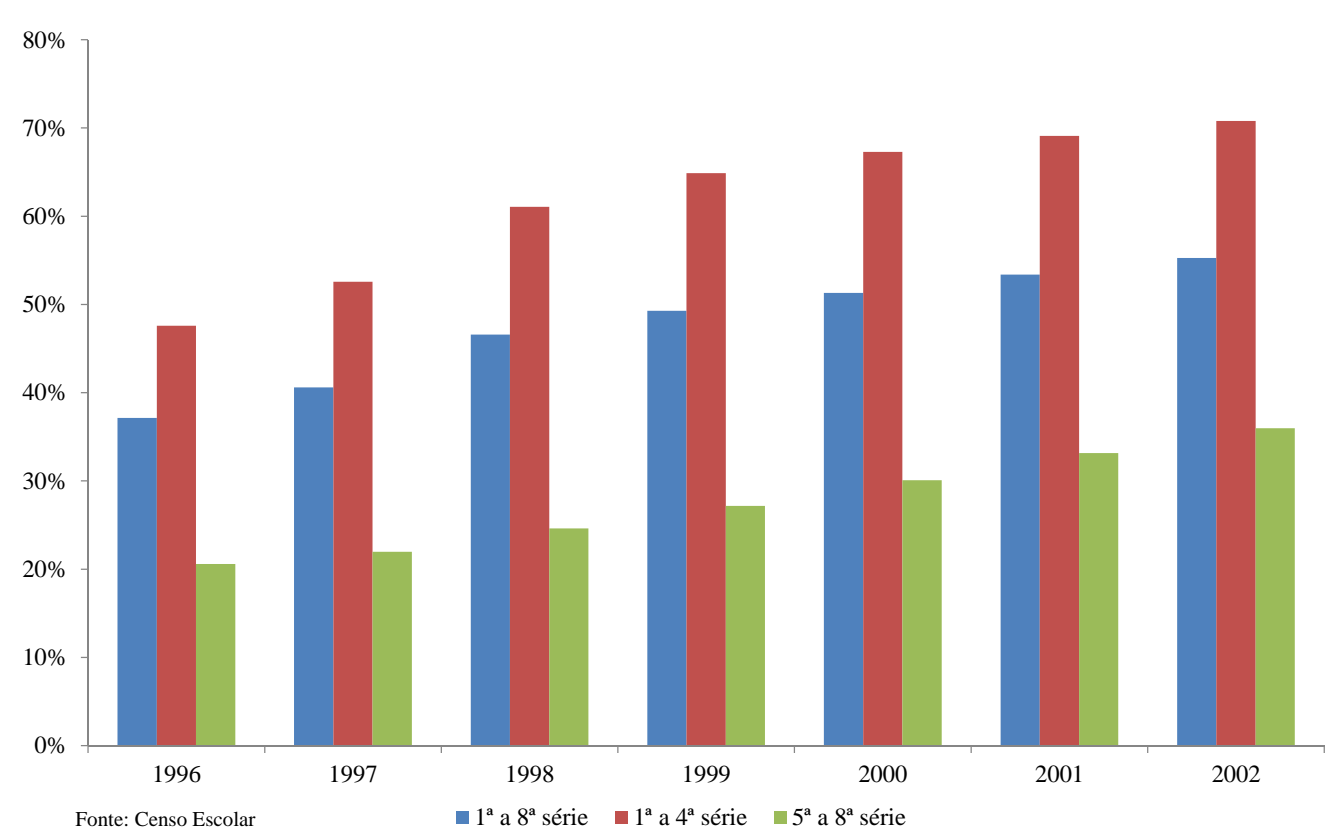

Figura 2: Proporção de matrículas do ensino fundamental em escolas municipais (1996 a 2002)

Até a implantação do FUNDEF, a municipalização não contava com o apoio dos professores das escolas estaduais e com o dos prefeitos dos municípios. Enquanto os primeiros temiam reduções salariais, os últimos preocupavam-se com o aumento do dispêndio com educação, decorrente da absorção de alunos das escolas do estado (DRAIBE et al., 1993). Porém, como já ressaltado, após a sua instituição disponibilidade de recursos passou a ficar associada ao número de alunos e não mais a capacidade financeira dos municípios, proporcionando-lhes um forte incentivo para assumir uma maior proporção de alunos do ensino fundamental e para tentar mantê-los na escola, a depender, claro, da relação de custos e valores por aluno (ORELLANO et al., 2011). O incentivo a municipalização não está relacionado apenas à tentativa de angariar recursos, mas também como alternativa de não perdê-los.

Contudo, antes de concluir que o aumento da proporção de alunos de $1^{a}$ a $8^{a}$ série resultou de uma política educacional propriamente dita, deve-se analisar se ele é decorrente de fatores demográficos, como o aumento do número de crianças em idade escolar matriculadas em escolas municipais, ou reflexo da correção do fluxo escolar, o que poderia ter ocorrido por meio da transição entre uma situação de repetência alta, fluxo distorcido e evasão alta para uma com menor repetência, fluxo regular e menor evasão ${ }^{20}$.

\footnotetext{
${ }^{20}$ Caso a queda da evasão escolar seja superior o número de concluintes do ensino fundamental, um fluxo mais
} 
O trabalho de Soares e Souza (2003) mostra que o aumento da proporção de alunos matriculados em escolas municipais coincidiu com o arrefecimento da pressão demográfica primária sobre o ensino fundamental. Ademais, a retenção de alunos decorrente de melhoras no fluxo escolar foi pequena quando comparada à municipalização observada. Dessa forma, pode-se concluir que a municipalização ocorrida no final da década de 90 foi majoritariamente resultado de políticas educacionais: de 1996 a 1999, a matrícula total do ensino fundamental aumentou em 2,9 milhões e a matrícula em escolas municipais aumentou em 5,2 milhões, quase o dobro.

Não existe um fator específico que ajude a explicar o porquê dos governos estaduais terem incentivado a municipalização. Alguns o fizeram por não desejar administrar pequenas escolas rurais, outros para passar os seus professores para séries mais elevadas e acompanhar a evolução demográfica da matrícula ou por considerar que a descentralização é uma boa prática administrativa (SOARES; SOUZA, 2003). Como já ressaltado anteriormente, os municípios incentivaram esse processo principalmente como alternativa de obter recursos adicionais ou, ao menos, não perdê-los.

O aumento da proporção de alunos do ensino fundamental matriculados em escolas municipais ocorreu por meio da criação dessas escolas em um ritmo maior do que a criação de escolas estaduais, do aumento do número médio de alunos por escolas, decorrente do aumento do número de turmas ou do aumento do número médio de alunos por turma, e da transferência de gestão de algumas escolas estaduais para os municípios. Embora grande parte da municipalização observada esteja relacionada à absorção de alunos que estavam matriculados na rede estadual, esse processo também pode ser explicado pela própria expansão do acesso ao ensino fundamental.

Entre 1996 a 2001, a municipalização observada nas escolas de $1^{a}$ a $4^{a}$ série decorreu majoritariamente do aumento do número médio de alunos por escola. Os estabelecimentos que tinham em média 65 alunos passaram a ter 100. Também contribuiu, embora em menor proporção, a troca de gestão de quase 10 mil escolas da rede estadual para municipal. Por outro lado, a criação líquida de escolas não esteve associada ao aumento da matrícula nesse ciclo, devido ao fechamento de aproximadamente 16 mil escolas municipais. Já a municipalização ocorrida no segundo ciclo do ensino fundamental decorreu, em primeiro lugar, do aumento de aproximadamente 9 mil escolas municipais. Em segundo lugar, por meio da elevação do número médio de 
alunos por escola, de 220 para 234 e, em menor parte, pela troca de gestão de quase mil escolas (SOARES; SOUZA, 2003).

Dessa forma, para o primeiro ciclo do ensino fundamental, a elevação do número de alunos por escolas foi responsável por $118 \%$ do aumento das matrículas municipais, enquanto coube à transferência de escolas 19\%. Por outro lado, o fechamento de muitas escolas municipais implicou queda de 38\% das matrículas. Quanto à municipalização ocorrida nas quatro séries finais, a criação líquida de escolas, o crescimento médio da matrícula e a troca de gestão entre redes foram responsáveis pelo aumento de 78\%, 12\% e 9\% das matrículas, respectivamente (SOARES; SOUZA, 2003).

Para a ex-secretária estadual da educação de São Paulo, Rose Neubauer, o aumento do número médio de alunos por escola pode representar um indicativo de que os gastos públicos estão sendo racionalizados: "uma escola com 65 alunos nem sempre é econômica e racional do ponto de vista do gasto público. Em escolas um pouco maiores, é mais fácil ter bibliotecas, laboratórios e coordenador pedagógico". Assim, segundo a ex-secretária, a municipalização decorrente do aumento do número de alunos por escola não compromete necessariamente a qualidade do ensino.

Por outro lado, para o ex-secretário estadual da educação da Bahia, Adaum Sauer, a transferência de alunos para os municípios deveria ter ocorrido concomitante ao aumento dos investimentos para a melhoria e a ampliação das escolas: "a municipalização, em tese, é uma ideia boa. Mas da maneira como foi feita, acabou por gerar alguns problemas. Alguns municípios tiveram que achar soluções improvisadas para receber novos estudantes”. David Plank, da Universidade de Michigan nos Estados Unidos, afirma que o FUNDEF, embora tenha contribuído para reduzir as disparidades regionais, aguçou a cobiça dos prefeitos pelo maior controle de recursos e a municipalização ocorreu de maneira desordenada e com perda de qualidade do ensino fundamental.

Em parte, o argumento que a municipalização ocorreu de forma desordenada decorre do fato de que muitos municípios não estavam preparados para formar uma equipe de profissionais qualificados, de modo a desempenhar as atividades necessárias para gerir de forma efetiva o sistema escolar. É necessária habilidade técnica para realizar um plano plurianual de investimentos em infraestrutura física, o que é apenas uma das responsabilidades de um sistema municipal de educação. O FUNDEF criou os incentivos para aumentar a matrícula, mas não gerou capacitação institucional para tirar proveito deles (BANCO MUNDIAL, 2002). Dessa forma, esperam-se 
respostas diferentes quanto às consequências da implantação do Fundo, dentre elas a municipalização, a depender do contexto em que as novas políticas foram aplicadas.

Alguns estudos empíricos já foram realizados com intuito de avaliar o impacto da municipalização, ou um de seus componentes específicos, em indicadores de rendimento ou resultados em exames de proficiência. É consensual o emprego do termo municipalização para o aumento da proporção de alunos do ensino fundamental matriculados em escolas municipais. A descentralização, por sua vez, consiste em uma das formas de municipalização e ocorre por meio da troca de gestão das escolas do estado para o município. D’Atri (2007), Orellano et al. (2011) e Banco Mundial (2002) estudam os efeitos da municipalização nos indicadores de rendimento. Razo (2004), Madeira (2007) e Leme, Paredes e Souza (2009) avaliam os impactos da descentralização das escolas estaduais. Os dois primeiros sobre os indicadores de rendimento e o último sobre notas obtidas em testes de proficiência.

O trabalho de D'Atri (2007) define o FUNDEF como uma política exógena responsável pela municipalização do ensino fundamental. Ao utilizar dados de 1998 e 2004, com objetivo de encontrar o efeito médio da municipalização no desempenho escolar, a autora emprega a metodologia de diferença em diferenças, de modo a comparar o desempenho da rede municipal, grupo de tratamento, com o da rede estadual, grupo de comparação, antes e depois da implantação do Fundo. Ao controlar as características das escolas, a autora encontra evidências de que os alunos da rede municipal apresentaram desempenho um pouco mais baixo do que os alunos da rede estadual. Tal constatação está refletida em maiores taxas de abandono e de distorção idade-série $^{21}$. No entanto, deve-se ressaltar que as escolas estaduais também estão sujeitas às regras de alocação dos recursos impostas pelo FUNDEF. Dessa forma, ao não se controlar a menor autonomia de gasto imposta aos estados e a redistribuição de recursos do Fundo, os resultados encontrados são possivelmente inconsistentes.

Em segundo lugar, ao empregar os municípios como unidades de observação, a autora propõe um modelo em que a municipalização é decomposta em expansão de rede (o efeito líquido da criação de escolas municipais e da descentralização de escolas estaduais), e migração de rede (o aumento do número médio de alunos em escolas municipais, dentro do qual está a absorção de alunos do estado e a expansão do acesso ao ensino fundamental). Os resultados encontrados são ambíguos, na medida em que existem evidências de que quanto maior a expansão da rede, maior a distorção idade-série, enquanto que quanto maior a migração de rede, menor a distorção.

\footnotetext{
${ }^{21}$ Os efeitos são significativos, embora pequenos.
} 
De alguma forma, esses resultados estão possivelmente relacionados ao fato de que ao se expandir a rede, é possível que as escolas tenham absorvido alunos com menor probabilidade de frequentá-las e que, portanto, apresentavam rendimento inferior. Por outro lado, o aumento do número de alunos por escolas municipais pode estar relacionado à transferência dos melhores alunos da rede estadual para a municipal. Dessa maneira, os resultados encontrados sugerem que embora a municipalização não tenha acarretado prejuízos aos alunos, também não é possível afirmar que tenha apresentado impacto positivo.

Razo (2004) analisa o efeito da municipalização das quatro primeiras séries, no que concerne à transferência de escolas entre as redes estadual e municipal, no atraso médio escolar e no percentual de alunos com defasagem maior que 2 anos. Primeiramente, a autora verifica em quais estados a municipalização decorrente da descentralização de escolas estaduais, entre 1996 e 1998, foi mais intensa e depois emprega para cada um deles a metodologia de diferença em diferenças com emparelhamento por scores de propensão ${ }^{22}$.

Os indicadores de rendimento das escolas descentralizadas, grupo de tratamento, são comparados com os indicadores de rendimento das escolas que permaneceram sob gestão estadual, grupo de comparação. Nos estados de Santa Catarina, Ceará e Bahia não foram encontradas mudanças significativas nas variáveis dependentes analisadas. Por outro lado, a autora encontra indicativos de que em Minas Gerais a municipalização contribuiu para a queda de qualidade do ensino fundamental. Esses resultados são condizentes com a hipótese que os municípios poderiam estar despreparados para receber maior número de alunos na sua rede de ensino fundamental.

Madeira (2007) estuda o impacto do programa de descentralização das escolas estaduais de São Paulo anunciado em 1995 pelo recém-eleito Governo do Estado. A adoção das escolas por parte dos municípios ocorreu de forma gradual e intensificou-se após a implantação do FUNDEF. Por meio de dados disponíveis entre 1996 a 2003, o autor avalia os resultados dessa política ao longo dos anos no que se refere às taxas de abandono e reprovação e à quantidade de insumos escolares como, por exemplo, número de equipamentos eletrônicos por aluno, tamanho da sala de aula, número médio de horas-aula por dia, porcentagem de docentes com ensino superior e número de alunos por professor para alunos de $1^{a}$ a $4^{a}$ série.

\footnotetext{
${ }^{22}$ Embora esse método compare as escolas com características observáveis mais próximas, ele não resolve o viés de seleção decorrente de variáveis não observáveis.
} 
Por meio de características socioeconômicas das regiões em que as escolas estão localizadas e características fiscais e eleitorais dos municípios, o autor emprega a metodologia de diferença em diferenças para tratamentos não aleatórios proposta por Heckman e Hotz (1989). Os resultados sugerem efeitos contraditórios para a descentralização por apontarem piora nos indicadores de rendimento dos alunos de $1^{a}$ a $4^{a}$ série, ao mesmo tempo em que evidenciam menor número de alunos por professor e aumento do número de equipamentos eletrônicos por estudante.

Parte desses resultados conflitantes podem ser explicados pela piora dos indicadores de rendimento nas duas primeiras séries, o que por sua vez, está parcialmente relacionado à universalização da educação básica. No que diz respeito aos aspetos distributivos da reforma, o autor encontra indícios de que o impacto da descentralização foi mais perverso nas escolas localizadas em regiões mais pobres e mais rurais. Por fim, os resultados também sugerem que a descentralização implicou aumento da desigualdade dos indicadores de rendimento entre as melhores e as piores escolas ${ }^{23}$.

Leme, Paredes e Souza (2009) analisam o impacto da troca de gestão das escolas da rede estadual para municipal nos resultados dos exames de proficiência em português e matemática obtidos por alunos da $4^{a}$ série. Por meio dos resultados do SAEB e da Prova Brasil ${ }^{24}$, os autores constroem painéis de escolas por pares de anos, 1997 e 2005, 1999 e 2005, 2001 e 2005 e 2003 e 2005, em que o ano inicial é constituído pelo resultado da escola no SAEB e o ano final pelo resultado da mesma escola na Prova Brasil. O grupo de tratamento é formado por escolas que inicialmente estão sob gestão do estado e em 2005 sob gestão do município, o grupo de comparação por escolas que são estaduais nos dois períodos de tempo. Ao controlar as características dos alunos e de suas famílias, a metodologia de diferença em diferenças fornece indicativos de que o efeito da municipalização foi nulo, tanto nos resultados dos exames de português quanto nos de matemática.

Os trabalhos empíricos citados buscam avaliar os impactos da maior autonomia municipal quanto ao gerenciamento de suas escolas. Os resultados encontrados apontam efeitos negativos ou nulos nos indicadores educacionais do ensino fundamental, exceto as evidências encontradas

\footnotetext{
${ }^{23} \mathrm{O}$ autor estabeleceu um ranking de escolas de acordo com suas taxas de abandono.

${ }^{24}$ Tanto o SAEB, Sistema de Avaliação da Educação Básica, quanto a Prova Brasil devem ser respondidos por alunos da $4^{a}$ e $8^{a}$ série, atualmente $5^{\circ}$ e $9^{o}$ ano. Enquanto o primeiro é realizado com base em uma amostra aleatória e estratificada de escolas, representativa aos níveis de rede e estados, a Prova Brasil é um exame aplicado a todas as escolas públicas com mais de 20 alunos na série.
} 
por Madeira (2007) com relação a alguns insumos escolares. Contudo, era de se esperar que a descentralização do ensino fundamental estivesse refletida na melhor qualidade da educação, por permitir que a direção das escolas se aproximasse mais da comunidade, o que garantiria o seu envolvimento na elaboração e implantação de novos programas. Esse resultado seria condizente com a literatura teórica que prevê efeitos benéficos para a descentralização por pressupor o estabelecimento de políticas que mais se adaptem às peculiaridades de cada município.

Contudo, a omissão da menor autonomia de gasto imposta aos estados e municípios pelo FUNDEF pode levar a superestimação ou subestimação do verdadeiro efeito da municipalização, a depender da correlação entre essas duas variáveis e do efeito da maior rigidez de gasto nas variáveis dependentes analisadas. Se a municipalização estiver positivamente correlacionada com a maior dependência fiscal, o viés será positivo se externalidades positivas associadas às regras do FUNDEF tenham superado a perda de eficiência decorrente da menor autonomia de gasto e negativo, caso contrário ${ }^{25}$. Ao avaliar os impactos da municipalização nos indicadores de rendimento dos alunos do ensino fundamental, os trabalhos de Orellano et al. (2011) e Banco Mundial (2002) também consideram a relação entre recursos advindos do FUNDEF e despesas com educação e cultura. Enquanto o primeiro deseja avaliar o efeito da maior rigidez de gasto, o segundo procura verificar os impactos da composição dos gastos nos indicadores de rendimento ${ }^{26}$.

Orellano et al. (2011) analisam os efeitos da municipalização do ensino fundamental, tanto no que diz respeito ao aspecto fiscal, quanto ao de gerenciamento das escolas, nas taxas de aprovação, abandono e distorção idade-série. O indicador de descentralização fiscal foi obtido por meio da relação entre os recursos recebidos pelo FUNDEF e o total de gastos com educação e cultura realizados pelos municípios. Quanto maior essa relação, mais os gastos com educação estão condicionados às transferências recebidas do Fundo. No que diz respeito à descentralização gerencial, os indicadores utilizados são a proporção de escolas municipais de $1^{a}$ a $8^{a}$ série e a proporção de alunos de $1^{a}$ a $8^{a}$ série matriculados em escolas municipais. Quanto maior forem ambos os indicadores, maior a autonomia gerencial do município.

Os indicadores de municipalização apresentaram efeito significativo e positivo sobre a distor-

\footnotetext{
${ }^{25}$ De maneira semelhante, se a municipalização estiver negativamente correlacionada com a dependência fiscal, o viés será negativo se externalidades positivas associadas às regras do FUNDEF tenham superado a perda de eficiência decorrente da menor autonomia de gasto e positivo, caso contrário.

${ }^{26} \mathrm{O}$ estudo deseja avaliar se a maior proporção de recursos oriundos do FUNDEF no total de gastos com educação afeta os indicadores de rendimento analisados.
} 
ção idade-série, quanto mais o município avança na absorção de alunos do ensino fundamental, maior o número médio de alunos com idade superior à recomendada para a série. Já com relação às taxas de aprovação e abandono não foram encontradas evidências de impacto da municipalização. Por outro lado, os resultados para o indicador de descentralização fiscal condizem com os efeitos previstos pela literatura: existem indícios de que a perda de autonomia fiscal imposta aos municípios implicou menores taxas de aprovação e maiores taxas de abandono e distorção idade-série.

O estudo do Banco Mundial (2002), sobre a educação municipal no Brasil, argumenta que após a LDB e a criação do FUNDEF, a combinação do aumento dos recursos e dos mecanismos de incentivo com relação ao seu uso levou a uma melhora da qualidade e da quantidade dos serviços de educação. O estudo decompõe o efeito do FUNDEF em três fatores principais: recursos adicionais, por meio da evolução do gasto por aluno das esferas estaduais e municipais, composição dos gastos, pela relação entre recursos do FUNDEF e despesas com educação e cultura, e municipalização induzida, por meio do aumento da proporção de alunos matriculados em escolas municipais. Para os dois ciclos do ensino fundamental, avaliam-se os efeitos de cada um desses fatores nas taxas de aprovação, abandono e distorção idade-série entre 1996 e 2000.

Para alunos de $1^{a}$ e $4^{a}$ série, encontram-se evidências de que o gasto por aluno realizado pelos governos estaduais e municipais apresentou efeitos positivos, ainda que em pequena magnitude, nos indicadores de rendimento avaliados. Da mesma maneira, o aumento da proporção de gastos com educação e cultura realizados com recursos do Fundo e, portanto, sujeitos às suas regras de alocação, apresentou impactos positivos refletidos em menores taxas de abandono, menores taxas de reprovação e maiores taxas de aprovação. Por fim, o estudo mostra que o grau de municipalização esteve positivamente relacionado aos resultados educacionais obtidos por alunos de $1^{a}$ a $4^{a}$ série. Em síntese, o estudo encontra indícios de que as inovações trazidas pelo FUNDEF contribuíram para o aumento dos indicadores educacionais avaliados.

A maior parte dos trabalhos empíricos realizados indicam que a municipalização apresentou impacto nulo ou negativo. Entretanto, a literatura ainda carece de trabalhos que tenham realizado uma análise mais detalhada dos dados de forma a entender como esse processo se adaptou à realidade dos municípios brasileiros. Ainda nesse sentido, é importante considerar que o FUNDEF apresentou vários desdobramentos, não apenas o incentivo à descentralização do ensino fundamental. Dessa forma, também é importante ponderar, dentre outros fatores, a redistribuição de recursos entre municípios de um mesmo estado e entre determinado estado e seus respec- 
tivos municípios, a menor autonomia de gasto decorrente das regras de alocação dos recursos do Fundo e o maior nível de qualificação dos professores. Ao desconsiderar esses fatores, que possivelmente estão correlacionados com a municipalização observada e com os indicadores educacionais avaliados, os estimadores encontrados serão possivelmente inconsistentes. 


\section{DESCRIÇÃO DOS DADOS}

O intuito deste trabalho é avaliar os impactos da municipalização, sobretudo no que concerne ao processo de transferência de gestão de algumas escolas estaduais para a administração municipal, nos indicadores de rendimento (taxas de aprovação, reprovação e abandono) e de distorção idade-série auferidos por alunos de $1^{a}$ a $4^{a}$ série. Para tanto, foram coletadas informações divulgadas pelo Instituto Nacional de Estudos e Pesquisas Educacionais (INEP), pela Secretaria do Tesouro Nacional (STN), pelo Instituto Brasileiro de Geografia e Estatística (IBGE) e pelo Tribunal Superior Eleitoral (TSE).

O INEP é uma autarquia federal vinculada ao Ministério da Educação e conta com apoio das secretarias estaduais e municipais da educação para a realização do Censo Escolar. Divulgada anualmente, a pesquisa consiste no levantamento de dados estatísticos-educacionais de todas as escolas públicas e privadas do país. É o principal instrumento de coleta de informações da Educação Básica utilizadas para traçar um panorama nacional da educação, além de servirem de referência para a formulação de políticas públicas e para a execução de programas na área de educação ${ }^{27}$.

Os dados coletados pelo Censo Escolar ${ }^{28}$ fornecem informações sobre a infraestrutura física das escolas e suas vinculações com programas de fomento à educação, por exemplo, Livro Didático $^{29}$, Merenda Escolar ${ }^{30}$, Dinheiro Direto na Escola ${ }^{31}$, Transporte Escolar ${ }^{32}$, TV na Escola ${ }^{33}$ e Programa Nacional de Tecnologia Educacional ${ }^{34}$. Também apresenta o número de docentes alocados por modalidade e nível de qualificação, e as características das turmas por série, juntamente com seus respectivos indicadores de rendimento e de distorção idade-série. Optou-se por coletar informações de escolas de $1^{a}$ a $4^{a}$ série pelo fato de a descentralização das escolas

\footnotetext{
${ }^{27}$ Por exemplo, merenda e transporte escolar, distribuição de livros e uniformes, implantação de bibliotecas, disponibilização de energia elétrica, entre outros (INEP).

${ }^{28}$ Os questionários se tornaram mais complexos ao longo do tempo, determinadas informações não estão disponíveis para todos os anos.

${ }^{29}$ Distribuição de livros didáticos para os alunos da Educação Básica.

${ }^{30}$ Recursos complementares para aquisição de gêneros alimentícios.

${ }^{31}$ Repasse de recursos do Fundo Nacional de Desenvolvimento da Educação para escolas de ensino fundamental com mais de 20 alunos matriculados.

${ }^{32}$ O Programa consiste no repasse de recursos financeiros para compra de veículos automotores destinados, exclusivamente, ao transporte de alunos matriculados no ensino fundamental e na educação especial das redes estadual e municipal, prioritariamente residentes no meio rural.

${ }^{33} \mathrm{O}$ programa abrange as escolas públicas com mais de 100 alunos para as quais foram repassados alguns equipamentos eletrônicos, por exemplo, TV, videocassete e antena parabólica.

${ }^{34}$ Consiste no repasse de computadores, recursos digitais e conteúdos educacionais aos estabelecimentos de ensino. Em contrapartida, estados, Distrito Federal e municípios devem garantir a estrutura adequada para receber os laboratórios e capacitar os educadores para uso das máquinas e tecnologias.
} 
estaduais, como será apresentado adiante, ter sido mais intensa nesse ciclo ${ }^{35}$.

A Tabela 1 apresenta as informações coletadas dos Censos Escolares divulgados de 1997 a 2002.

Tabela 1: Informações coletadas do Censo Escolar

\begin{tabular}{|c|c|c|}
\hline & & Indicadores \\
\hline $\begin{array}{c}\text { Informações } \\
\text { para escolas } \\
\text { públicas } \\
\text { estaduais e } \\
\text { municipais }\end{array}$ & $\begin{array}{c}\text { Variáveis } \\
\text { independentes } \\
\text { agregadas de } \\
1^{a} \text { a } 4^{a} \text { série }\end{array}$ & $\begin{array}{l}\text { Taxa de abandono } \\
\text { Taxa de aprovação } \\
\text { Taxa de reprovação } \\
\text { Taxa de distorção idade-série } \\
\text { Disponibilização de ensino fundamental de } 5^{a} \text { a } 8^{a} \text { série } \\
\text { Escola localizada em área urbana ou rural } \\
\text { Existência de biblioteca } \\
\text { Existência de laboratório } \\
\text { Acesso à energia elétrica } \\
\text { Acesso à água } \\
\text { Acesso ao saneamento básico } \\
\text { Proporção de docentes com ensino superior } \\
\text { Número médio de alunos por turma } \\
\text { Total de turmas } \\
\text { Proporção de meninas matriculadas } \\
\text { Total de matrículas } \\
\text { Total de funcionários } \\
\text { Recursos por sala } \\
\text { Participação no Programa Nacional do Livro Didático } \\
\text { Particiação no Programa Nacional de Alimentação Escolar } \\
\text { Participação no Programa Dinheiro Direto na Escola } \\
\text { Participação no Programa Nacional Transporte Escolar } \\
\text { Participação no Programa TV Escola } \\
\text { Participção o Programa Nacional de Tecnologia Educacional }\end{array}$ \\
\hline
\end{tabular}

a A variável recursos por sala foi obtida por meio da divisão entre o total de equipamentos eletrônicos por escola (televisão, impressora, computador, videocassete, retroprojetor e aparelho de som) e número total de salas de aula.

b O Censo Escolar de 1997 não divulgou a quantidade de meninas matriculadas por série e a proporção de docentes com ensino superior. De tal modo, foram adotados os valores de 1996 para aquele ano.

Fonte: Elaboração própria

\footnotetext{
${ }^{35}$ Conforme ressaltado no trabalho de Soares e Souza (2003), a descentralização de algumas escolas estaduais é o segundo fator que mais explica a municipalização observada no primeiro ciclo do ensino fundamental.
} 
Entre 1997 e 1998, as taxas de aprovação, reprovação e abandono para $1^{a}, 2^{a}, 3^{a}$ e $4^{a}$ série foram calculadas com base no número de alunos que aprovaram, reprovaram ou abandonaram a escola. Idealmente, para o cálculo da taxa de aprovação, por exemplo, seria necessário dividir o total de alunos aprovados na série $k$, pela respectiva matrícula final na série. Este indicador é obtido por meio da soma de alunos inicialmente matriculados com os alunos admitidos, subtraída do total de alunos transferidos. Contudo, em muitos casos, a soma de aprovações, reprovações e abandonos difere da matrícula final divulgada pelo estabelecimento de ensino. De tal modo, construiu-se um indicador de matrícula final por série, obtido por meio da soma de alunos que aprovaram, reprovaram ou abandonaram a escola. Dessa forma, para obtenção da taxa de aprovação por série, por exemplo, dividiu-se o total de alunos aprovados pelo indicador de matrícula final ${ }^{36}$.

Para o mesmo período, a taxa de distorção idade-série foi calculada dividindo-se o número de alunos com idade superior a recomendada para a série $k$ pelo total de alunos inicialmente matriculados nessa série. Os indicadores de rendimento e de distorção idade-série, agregados para o primeiro ciclo do ensino fundamental, foram calculados com base em média simples dos indicadores por série ${ }^{37}$. De 1999 a 2002, os indicadores foram disponibilizados já calculados, tanto para cada uma das séries quanto agregados de $1^{a}$ a $4^{a}$ série.

Para obtenção das características dos municípios em que as escolas estão localizadas, utilizaramse dados da STN, do IBGE e do TSE. Primeiramente, a Secretaria do Tesouro Nacional é o órgão central do Sistema de Administração Financeira Federal e do Sistema de Contabilidade Federal. A Secretaria é responsável pela divulgação do Finbra, Finanças do Brasil, que consiste no relatório de dados contábeis dos municípios. É possível acompanhar a evolução das receitas e despesas declaradas pelos governos municipais. Dessa forma, tem-se conhecimento, por exemplo, do valor despendido nas áreas de educação, cultura, habitação, saneamento e saúde. Os municípios também divulgam a evolução das receitas municipais, como recursos advindos do Fundo de Participação dos Municípios (FPM), o valor que lhes foi repassado de ICMS pelos respectivos governos estaduais e os valores que lhes foram redistribuídos pelo FUNDEF.

Quanto às transferências constitucionais realizadas aos governos municipais, como o FPM e o FUNDEF, optou-se por utilizar dados repassados diretamente pelo Tesouro Nacional. Os dados do Finbra, por serem autodeclarados, algumas vezes diferem do valor que a União afirma

\footnotetext{
${ }^{36} \mathrm{~A}$ mesma metodologia foi adotada para obtenção das taxas de reprovação e abandono.

${ }^{37}$ Metodologia do INEP para o período em análise.
} 
ter transferido aos governos municipais. No âmbito dos governos estaduais, o Tesouro Nacional divulga as transferências constitucionais realizadas aos estados, o que engloba os recursos advindos do FUNDEF e do Fundo de participação dos Estados. A STN também informa a arrecadação estadual com Imposto sobre Circulação de Mercadorias e Serviços (ICMS) e despesas realizadas com educação e cultura pelos 26 estados e pelo Distrito Federal.

Em segundo lugar, foram utilizadas informações divulgadas pelo Instituto Brasileiro de Geografia e Estatística. O IBGE é uma entidade da administração pública federal, vinculada ao Ministério do Planejamento responsável pela produção, análise, coordenação e consolidação de informações estatísticas e geográficas. Para este trabalho, no âmbito dos municípios, foram coletados o PIB, o número total de habitantes e a renda per capita.

Por fim, foram utilizadas informações do Tribunal Superior Eleitoral. O TSE é o órgão máximo da Justiça Eleitoral, responsável por divulgar o resultado de todas as eleições do país. É possível ter conhecimento da quantidade de votos recebida por cada candidato e a porcentagem de votos recebida por cada um dos partidos. Dessa forma, toma-se conhecimento do partido do presidente, dos governadores e dos prefeitos eleitos, bem como a composição partidária do Senado, Câmara dos Deputados e dos Vereadores. Neste trabalho utilizaram-se as informações partidárias dos prefeitos eleitos entre 1997 e 2002 nos municípios brasileiros, de modo a determinar se prefeitos de determinados partidos são mais propensos a descentralizarem as escolas estaduais $^{38}$.

A Tabela 2 sintetiza as informações coletadas no âmbito dos estados e municípios.

\footnotetext{
${ }^{38}$ Verificou-se que 47,6\% dos municípios que apresentaram escolas descentralizadas eram governados por prefeitos ou do PSDB, ou do PMDB, ou do PFL.
} 
Tabela 2: Informações coletadas no âmbito dos estados e dos municípios

\begin{tabular}{|c|c|c|}
\hline \multirow{3}{*}{ Estados } & \begin{tabular}{l}
\multicolumn{1}{c}{ Dados } \\
Transferências do FUNDEF \\
FPE \\
Lei complementar $87 / 96$ \\
IPI-EXP \\
ICMS \\
Educação e cultura
\end{tabular} & $\begin{array}{c}\text { Secretaria do } \\
\text { Tesouro Nacional (STN) }\end{array}$ \\
\hline & $\begin{array}{l}\quad \text { Variáveis elaboradas } \\
\text { Dependência fiscal do governo estadual } \\
\text { Ganho líquido com o FUNDEF }\end{array}$ & $\begin{array}{c}\text { Fonte } \\
\text { Combinação de } \\
\text { dados do STN }\end{array}$ \\
\hline & Gasto por aluno de $1^{a}$ a $8^{a}$ série & $\begin{array}{l}\text { Combinação de dados } \\
\text { do STN e do Censo Escolar }\end{array}$ \\
\hline \multirow{7}{*}{ Municípios } & \begin{tabular}{l}
\multicolumn{1}{c}{ Dados } \\
Transferências do FUNDEF \\
FPM \\
Lei complementar $87 / 96$ \\
ICMS
\end{tabular} & $\begin{array}{c}\text { Fonte } \\
\text { Secretaria do } \\
\text { Tesouro Nacional (STN) }\end{array}$ \\
\hline & $\begin{array}{l}\text { IPI-EXP } \\
\text { Educação e cultura }\end{array}$ & Finbra. \\
\hline & $\begin{array}{l}\quad \text { Variáveis elaboradas } \\
\text { Dependência fiscal do governo municipal } \\
\text { Ganho líquido com o FUNDEF }\end{array}$ & $\begin{array}{c}\text { Fonte } \\
\text { Combinação de dados do STN }\end{array}$ \\
\hline & Gasto por aluno de $1^{a}$ a $8^{a}$ série & $\begin{array}{l}\text { Combinação de dados } \\
\text { do STN e do Censo Escolar }\end{array}$ \\
\hline & Superávit ou déficit fiscal & Finbra - STN \\
\hline & $\begin{array}{l}\text { População } \\
\text { PIB per capita municipal } \\
\text { Renda per capita }\end{array}$ & IBGE \\
\hline & Partido dos prefeitos & Tribunal Superior Eleitoral (TSE) \\
\hline
\end{tabular}

Fonte: Elaboração própria

Os indicadores de dependência fiscal dos estados e dos municípios foram obtidos por meio da relação entre os recursos advindos do FUNDEF e as despesas realizadas com educação e cultura. Quanto maior essa relação, mais dependentes das transferências do FUNDEF eram esses entes federativos. Dessa forma, maior era a rigidez de gasto imposta aos estados e municípios, uma vez que $60 \%$ dos recursos do Fundo deveriam ser destinados ao pagamento de professores em exercício e profissionais de suporte pedagógico.

Os indicadores de ganho líquido com o FUNDEF, dos estados e dos municípios, foram obtidos por meio da subtração entre o valor total redistribuído a esses entes pelo Fundo e o montante total contribuído. Consequentemente, é possível saber se os governos estaduais e municipais contribuíram mais do que arrecadaram com o FUNDEF, ou o contrário. Quando o ganho líquido foi positivo, os entes federativos foram classificados como "beneficiários", quando foi negativo como "doadores". 
Em suma, com base em informações dos estabelecimentos de ensino e em características dos estados e municípios em que eles estão localizados, construíram-se dois painéis entre os anos de 1997 e 2002. O primeiro deles tem como unidade de observação os municípios ${ }^{39}$, para os quais se acompanham as características médias dos estabelecimentos de ensino, os indicadores de rendimento e de distorção idade-série agregados para o primeiro ciclo do ensino fundamental, as características estaduais e municipais explicitadas na Tabela 2, e a evolução da municipalização. Este processo está refletido no aumento da proporção de alunos de $1^{a}$ a $4^{a}$ série matriculados em escolas municipais. Concomitantemente, em alguns municípios, também é possível notar o aumento da proporção de escolas municipais de $1^{a}$ a $4^{a}$ série no total de escolas ${ }^{40}$.

Os indicadores de rendimento e de distorção idade série agregados no nível municipal consistem na média ponderada dos indicadores auferidos por alunos matriculados em escolas estaduais e municipais. Como ponderação, utilizou-se a matrícula total dos estabelecimentos de ensino. Dessa forma, escolas com menor número de alunos apresentam menor peso na construção do índice agregado e o oposto ocorre para escolas com maior número de alunos.

O segundo painel elaborado tem como unidades de observação escolas descentralizadas e escolas que permaneceram sob gestão estadual. Com base nos dados apresentados na Tabela 1 e Tabela 2, acompanham-se as características dos estabelecimentos de ensino e dos estados e municípios em que eles estão localizados ${ }^{41}$.

A Tabela 3 apresenta os indicadores de rendimento e de distorção idade-série, referentes a 1997 e a 2002, para o Brasil e para cada uma das cinco regiões. Os indicadores foram construídos com base no desempenho de alunos matriculados em escolas estaduais e municipais. $\mathrm{O}$ teste de médias realizado revela que em todas as regiões do Brasil houve mudança positiva, e

\footnotetext{
${ }^{39}$ O painel apresenta em 1997: 5.178 municípios; em 1998: 5.260; em 1999: 5.334; em 2000: 5.342; em 2001 5.376; e em 2002: 5.404.

${ }^{40}$ As estatísticas descritivas dos municípios da amostra estão apresentadas no Apêndice A.1 deste trabalho.

${ }^{41}$ Tanto do painel de municípios quanto do painel dos estabelecimentos de ensino, foram excluídas algumas escolas que mudaram a resposta "município de localização" nos questionários do Censo Escolar entre 1997 e 2002. Também foram excluídas as escolas nas quais a matrícula final (soma da matrícula inicial com o saldo da subtração entre alunos admitidos e transferidos) destoou muito do indicador de matrícula final estabelecido (soma das aprovações, reprovações e abandonos). Para tanto, construiu-se uma nova variável $r$ dada pela divisão entre matrícula final e indicador de matrícula final. Em seguida foram excluídos os estabelecimentos que apresentavam $r>2$ ou $r<0.5$. Poderia ter sido adotada uma regra de exclusão de outlier dada por: $r>Q 1-3 / 2(Q 3-Q 1)$ ou $r>Q 1-3 / 2(Q 3-Q 1)$, em que $Q 1$ e $Q 2$ são o primeiro e o segundo quartil da distribuição de $r$. No entanto, por meio dessa regra perde-se boa parte da amostra de dados. Por fim, também foram excluídos os estabelecimentos de ensino que declararam matrícula inicial ou matrícula final iguais a zero.
} 
estatisticamente significante, de tais indicadores.

Tabela 3: Estatísticas descritivas dos indicadores de rendimento e de distorção idade-série para alunos de $1^{a}$ a $4^{a}$ série (1997 e 2002)

\begin{tabular}{|c|c|c|c|c|c|}
\hline & & \multicolumn{4}{|c|}{ Brasil } \\
\hline $\begin{array}{l}1997 \\
2002\end{array}$ & $\begin{array}{l}\text { Média } \\
\text { Erro padrão } \\
\text { Média } \\
\text { Erro padrão }\end{array}$ & $\begin{array}{c}\text { Tx. de abandono } \\
0,095^{* * *} \\
(0,001) \\
0,066^{* * *} \\
(0,001)\end{array}$ & $\begin{array}{c}\text { Tx. de reprovação } \\
0,133 \\
(0,001) \\
0,133 \\
(0,001)\end{array}$ & $\begin{array}{c}\text { Tx. de aprovação } \\
0,772 * * * \\
(0,002) \\
0,799 * * * \\
(0,002) \\
\text { entro Oeste }\end{array}$ & $\begin{array}{c}\text { Tx. de distorção idade-série } \\
0,425^{* * *} \\
(0,003) \\
0,329^{* * *} \\
(0,002)\end{array}$ \\
\hline 1997 & $\begin{array}{l}\text { Média } \\
\text { Erro padrão } \\
\text { Média } \\
\text { Erro padrão }\end{array}$ & $\begin{array}{c}\text { Tx. de abandono } \\
0,110^{* * *} \\
(0,002) \\
0,091 * * * \\
(0,003)\end{array}$ & $\begin{array}{c}\text { Tx. de reprovação } \\
0,138^{* * *} \\
(0,003) \\
0,115^{* * *} \\
(0,003)\end{array}$ & $\begin{array}{c}\text { Tx. de aprovação } \\
0,751^{* * *} \\
(0,003) \\
0,784 * * * \\
(0,005) \\
\text { Sudeste }\end{array}$ & $\begin{array}{c}\text { Tx. de distorção idade-série } \\
0,441^{* * *} \\
(0,005) \\
0,305^{* * *} \\
(0,005)\end{array}$ \\
\hline 1997 & $\begin{array}{l}\text { Média } \\
\text { Erro padrão } \\
\text { Média } \\
\text { Erro padrão }\end{array}$ & $\begin{array}{c}\text { Tx. de abandono } \\
0,047 * * * \\
(0,001) \\
0,030 * * * \\
(0,001)\end{array}$ & $\begin{array}{l}\text { Tx. de reprovação } \\
0,057 * * * \\
(0,001) \\
0,089 * * * \\
(0,002)\end{array}$ & $\begin{array}{c}\text { Tx. de aprovação } \\
0,896^{* * *} \\
(0,002) \\
0,880^{* * *} \\
(0,002) \\
\text { Sul }\end{array}$ & $\begin{array}{c}\text { Tx. de distorção idade-série } \\
0,266^{* * *} \\
(0,003) \\
0,224^{* * *} \\
(0,003)\end{array}$ \\
\hline 1997 & $\begin{array}{l}\text { Média } \\
\text { Erro padrão } \\
\text { Média } \\
\text { Erro padrão }\end{array}$ & $\begin{array}{c}\text { Tx. de abandono } \\
0,030 * * * \\
(0,001) \\
0,013 * * * \\
(0,001)\end{array}$ & $\begin{array}{l}\text { Tx. de reprovação } \\
0,121 * * * \\
(0,001) \\
0,102 * * * \\
(0,002)\end{array}$ & $\begin{array}{c}\text { Tx. de aprovação } \\
0,849^{* * *} \\
(0,002) \\
0,883^{* * *} \\
(0,002) \\
\text { Nordeste }\end{array}$ & $\begin{array}{c}\text { Tx. de distorção idade-série } \\
0,207 * * * \\
(0,003) \\
0,181^{* * *} \\
(0,002)\end{array}$ \\
\hline 2002 & $\begin{array}{l}\text { Média } \\
\text { Erro padrão } \\
\text { Média } \\
\text { Erro padrão }\end{array}$ & $\begin{array}{c}\text { Tx. de abandono } \\
0,162 * * * \\
(0,001) \\
0,114 * * * \\
(0,001)\end{array}$ & $\begin{array}{c}\text { Tx. de reprovação } \\
0,197 * * * \\
(0,002) \\
0,189 * * * \\
(0,002)\end{array}$ & $\begin{array}{c}\text { Tx. de aprovação } \\
0,641^{* * *} \\
(0,002) \\
0,695 * * * \\
(0,002) \\
\text { Norte }\end{array}$ & $\begin{array}{c}\text { Tx. de distorção idade-série } \\
0,669^{* * *} \\
(0,003) \\
0,495^{* * *} \\
(0,003)\end{array}$ \\
\hline 1997 & $\begin{array}{l}\text { Média } \\
\text { Erro padrão } \\
\quad \text { Média } \\
\text { Erro padrão }\end{array}$ & $\begin{array}{c}\text { Tx. de abandono } \\
0,163 * * * \\
(0,004) \\
0,114 * * * \\
(0,003)\end{array}$ & $\begin{array}{c}\text { Tx. de reprovação } \\
0,187 * * * \\
(0,003) \\
0,172 * * * \\
(0,003)\end{array}$ & $\begin{array}{c}\text { Tx. de aprovação } \\
0,650 * * * \\
(0,005) \\
0,711^{* * *} \\
(0,005)\end{array}$ & $\begin{array}{c}\text { Tx. de distorção idade-série } \\
0,596^{* * *} \\
(0,005) \\
0,468^{* * *} \\
(0,006)\end{array}$ \\
\hline
\end{tabular}

a A hipótese nula é dada por: $\mu_{1997}=\mu_{2002}$, em que $\mu$ é a média de cada um dos indicadores educacionais apresentados. Para as cinco regiões do Brasil e para os quatro indicadores avaliados, os testes realizados, a $1 \%$ de significância, permitem rejeitar tal hipótese.

$* * *$ significante a $1 \%, * *$ significante a $5 \%$ e $*$ significante a $10 \%$ 
Existem diversos fatores que podem ter sido responsáveis pela melhora de tais indicadores educacionais. Nesse ponto, deseja-se verificar se os desdobramentos da implantação do FUNDEF explicam parte dessas mudanças. Como já ressaltado, o Fundo, entre outros fatores, estimulou a absorção de alunos do ensino fundamental em escolas municipais, implicou redistribuição de recursos entre estados e municípios e entre municípios ricos e pobres em um mesmo estado, e impôs maior rigidez de gasto a esses entes federativos.

De acordo com a literatura que prevê efeitos benéficos para a descentralização de serviços públicos, a melhora dos indicadores para o primeiro ciclo do ensino fundamental pode estar associada à expansão da gestão municipal. A municipalização aproximou a comunidade da gestão dos estabelecimentos de ensino e aproximou os professores e diretores das escolas municipais dos secretários municipais da educação.

Por outro lado, o melhor desempenho dos alunos de $1^{a}$ a $4^{a}$ série pode estar relacionado à redistribuição de recursos de acordo com o número de matrículas ou à imposição de que $60 \%$ dos recursos do Fundo sejam alocados com professores em efetivo exercício e com profissionais de suporte pedagógico. É provável que as externalidades positivas decorrentes das regras de alocação dos recursos tenham mais do que contrabalanceado os feitos negativos decorrentes da maior rigidez. Contudo, em alguns casos, tais regras podem ter sido contrárias as necessidades dos municípios.

Primeiramente, com relação à redistribuição de recursos do FUNDEF, a Figura 3 apresenta os ganhos líquidos auferidos pelos governos estaduais e pelos seus respectivos municípios em 1998, primeiro ano de vigência do Fundo. Já é possível perceber a redistribuição de recursos dos estados para os municípios. 


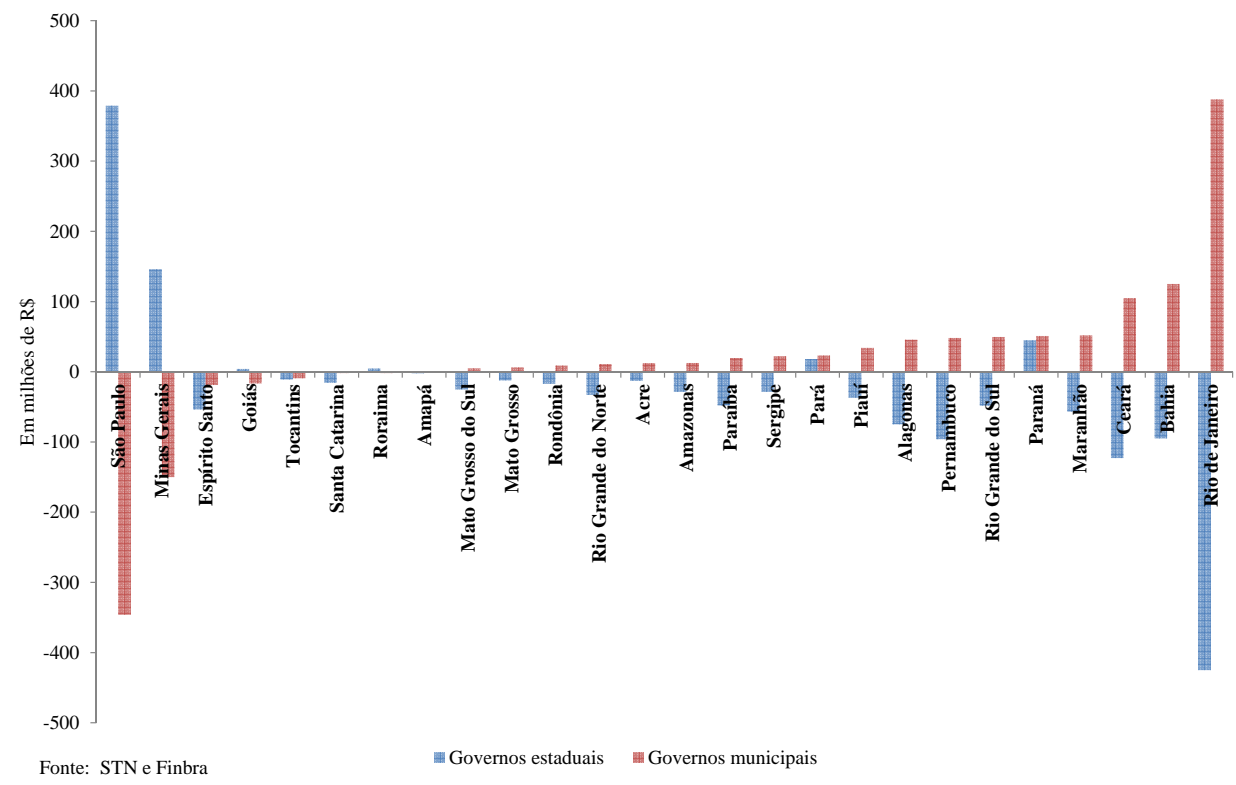

Figura 3: Ganho líquido dos estados e dos municípios com o FUNDEF (1998)

No quinto ano de vigência do FUNDEF, a redistribuição de recursos é ainda mais evidente. Apenas os municípios de Roraima contribuíram mais do que arrecadaram com o Fundo (Figura $4)$. 


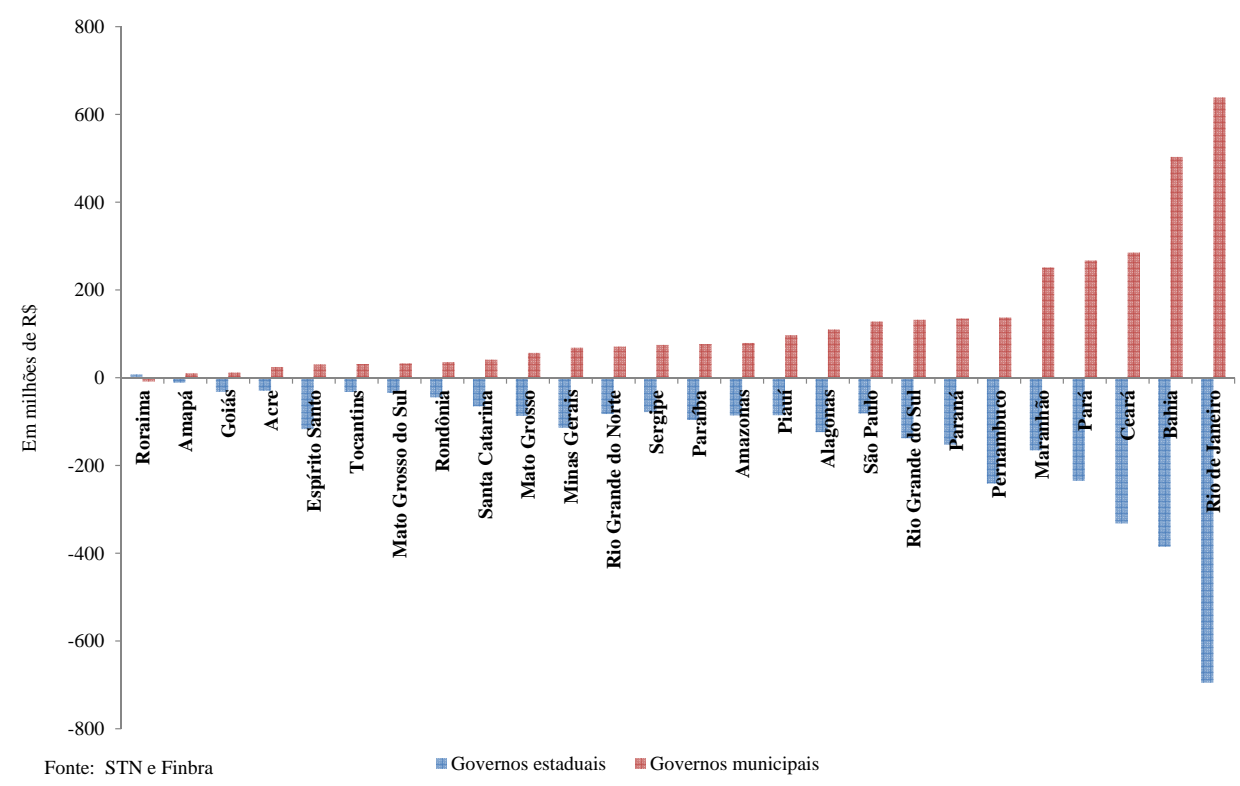

Figura 4: Ganho líquido dos estados e dos municípios com o FUNDEF (2002)

Como já ressaltado na Revisão de Literatura, essa redistribuição de recursos entre estados e seus respectivos municípios de fato contribuiu para que a distribuição de gasto por aluno, realizada pelos governos municipais com o ensino fundamental, tenha se tornado menos desigual entre 1997 e 2002.

No que concerne à maior rigidez de gasto imposta aos municípios, a Figura 5 apresenta a relação média entre os recursos oriundos do FUNDEF e as despesas realizadas com educação e cultura pelos governos municipais. Para a agregação dos dados no âmbito estadual, em 1998 e em 2002, ponderaram-se as dependências fiscais dos municípios pelo total de gasto realizado com educação e cultura. Dessa forma, municípios que realizaram maiores dispêndios com educação e cultura apresentam maior peso na análise e o oposto ocorre para municípios com menores níveis de gasto. 

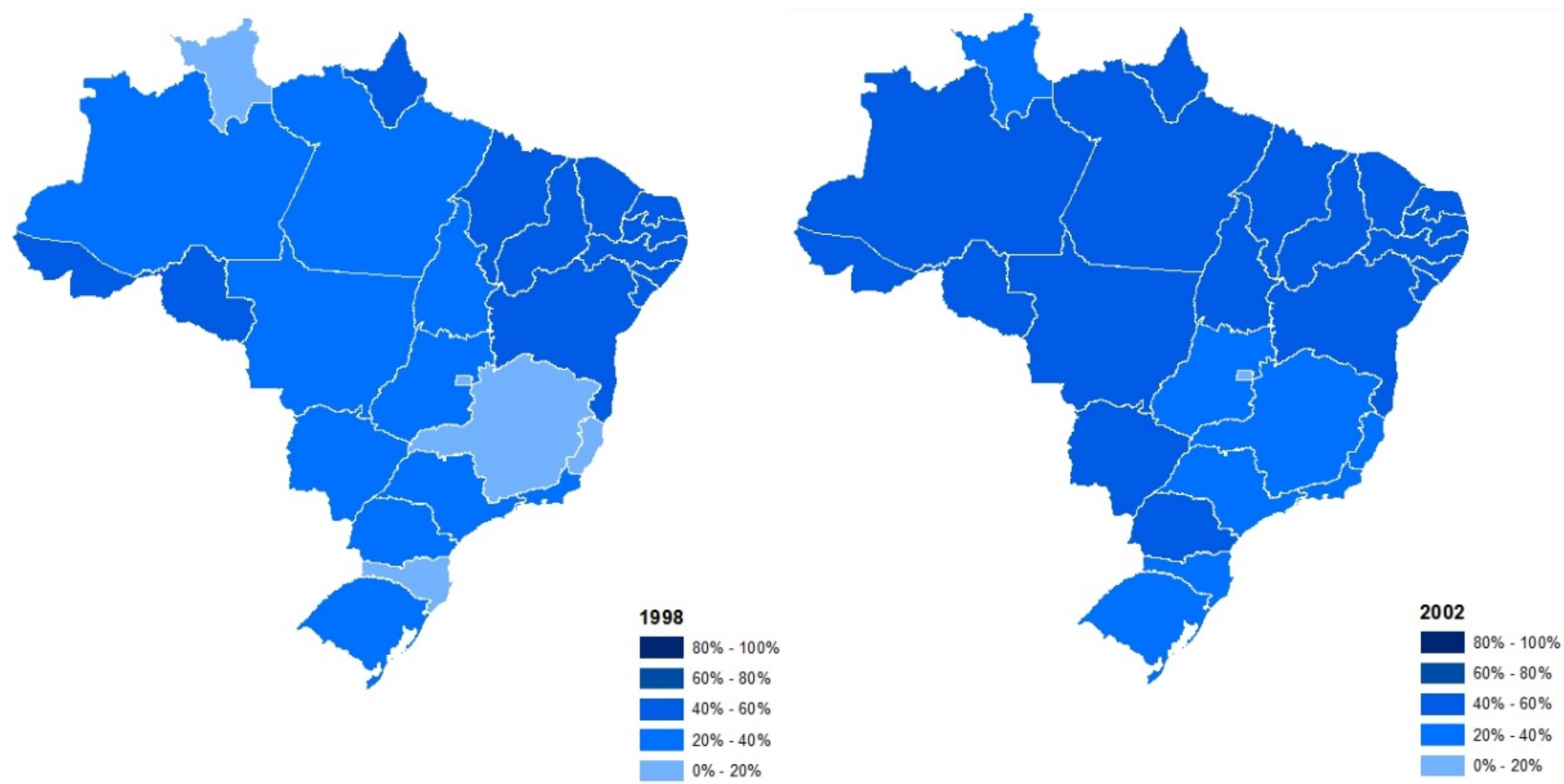

Figura 5: Relação média entre os recursos do FUNDEF e os gastos com educação e cultura no âmbito dos governos municipais (1998 e 2002) 
É possível perceber que já em 1998, os municípios mais dependentes de recursos do FUNDEF concentravam-se no Nordeste. A dependência de recursos do Fundo também superava $40 \%$ nos municípios do Acre, do Amapá e de Rondônia. Nota-se que entre 1998 e 2002, os municípios se tornaram mais dependentes de recursos do Fundo. Em parte, esse movimento pode ser explicado pela municipalização observada no período, como será apresentado adiante.

Importante ressaltar que a menor autonomia de gasto também foi imposta aos governos estaduais. A Figura 6 apresenta a relação média entre recursos oriundos do FUNDEF e gastos com educação e cultura dos governos estaduais para os anos de 1998 e 2002. 


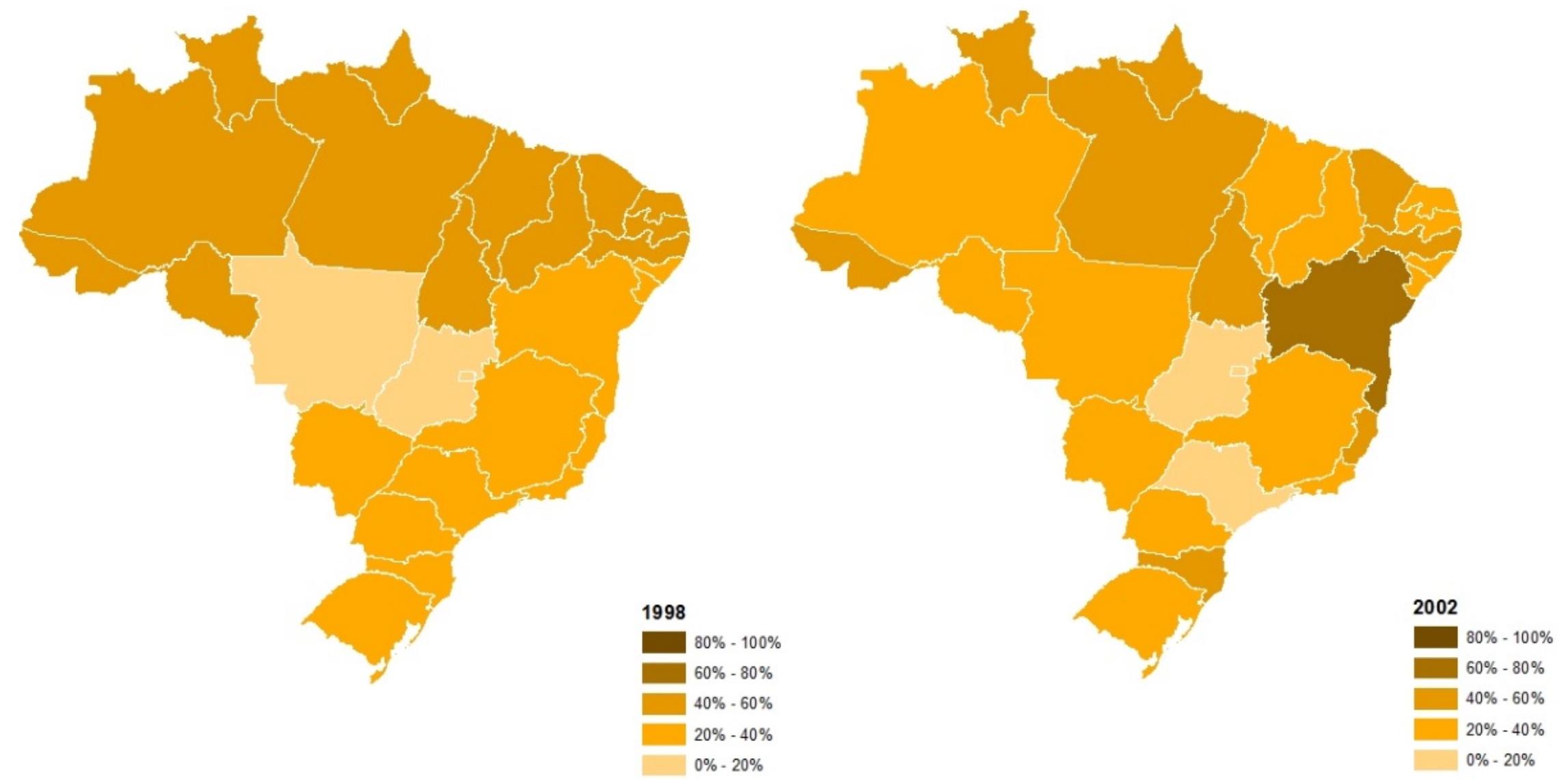

Figura 6: Relação média entre os recursos do FUNDEF e os gastos com educação e cultura no âmbito dos governos estaduais (1998 e 2002) 
No âmbito dos governos estaduais, verifica-se que, tanto em 1998 quanto em 2002, os estados do Nordeste e do Norte eram os que mais dependiam de recursos do FUNDEF. Enquanto que na maior parte dos estados dessas regiões houve aumento do indicador de dependência fiscal, nos estados do Centro-Oeste, Sudeste e Sul nota-se queda do indicador.

Por fim, um dos desdobramentos mais evidentes do FUNDEF foi municipalização do ensino fundamental. Ao condicionar as transferências ao número de alunos matriculados nessa etapa da educação básica, o Fundo criou uma gama de incentivos para que os municípios absorvessem um maior número de alunos, tanto que a proporção de alunos de $1^{a}$ a $4^{a}$ série matriculados em escolas municipais passou de 47,6\% em 1996 para 70,8\% em 2002. Para o segundo ciclo do ensino fundamental, $5^{a}$ a $8^{a}$ série, os percentuais são de $20,8 \%$ e $36,0 \%$, respectivamente. Essa mudança pode ser explicada pelo fato de que, nesse período, aproximadamente $88 \%$ dos municípios apresentaram aumento na proporção de alunos matriculados em suas escolas ${ }^{42}$.

A Figura 7 apresenta para os anos de 1997 e 2002, a proporção de alunos de $1^{a}$ a $4^{a}$ série matriculados em escolas municipais. Para obtenção do indicador agregado por estado, ponderaram-se as proporções de cada município pelas respectivas matrículas no primeiro ciclo do ensino fundamental. De tal modo, um peso maior é atribuído aos municípios que apresentam maior número de alunos matriculados em seus estabelecimentos de ensino, e menor caso contrário.

\footnotetext{
${ }^{42}$ Esse percentual refere-se a matrícula de $1^{a}$ a $8^{a}$ serie. Para a $1^{a}$ a $4^{a}$ e $5^{a}$ a $8^{a}$ série, os percentuais são de $87,9 \%$ e $69,6 \%$, respectivamente.
} 


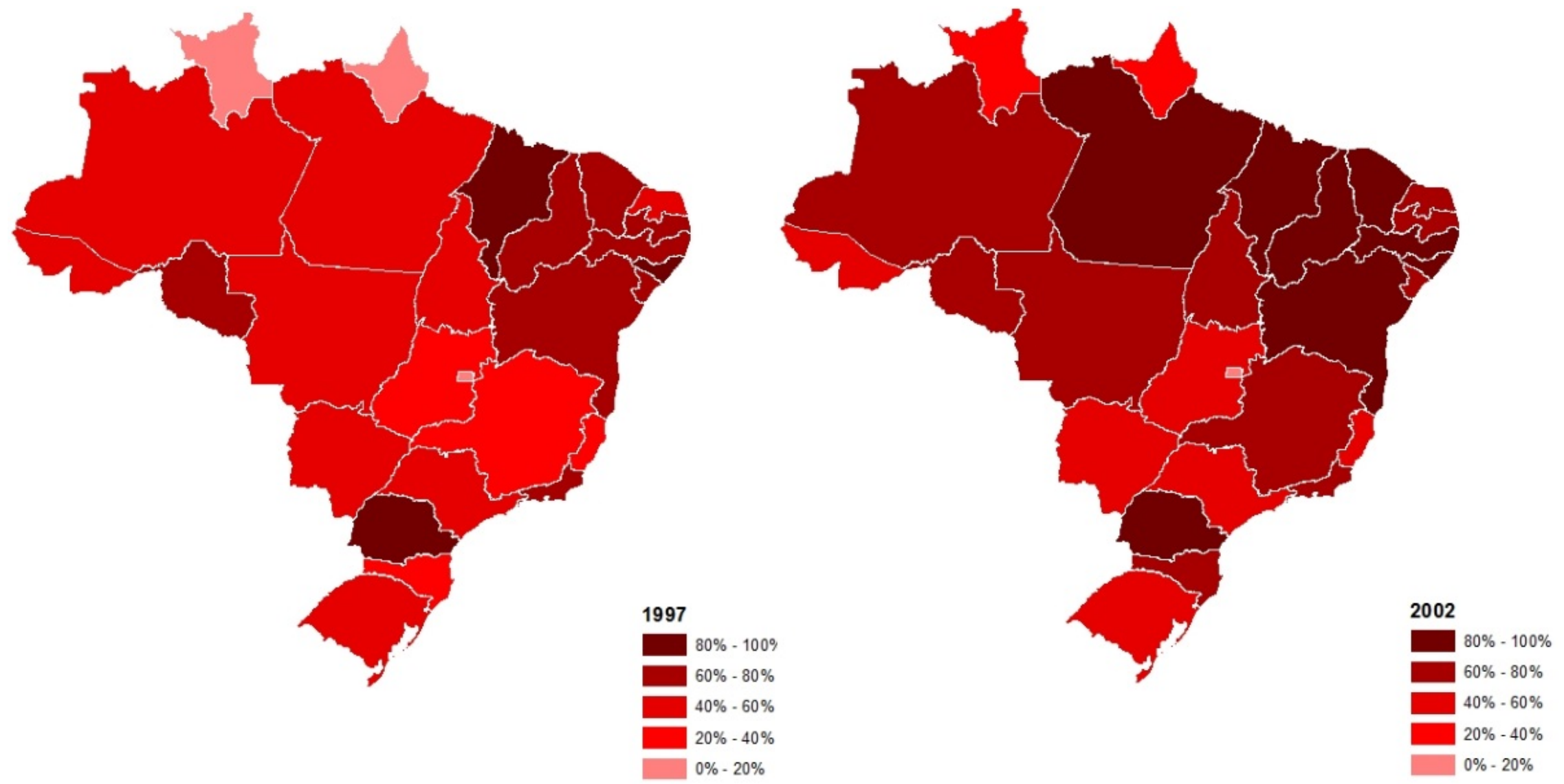

Figura 7: Proporção de matrículas de $1^{a}$ a $4^{a}$ série em escolas municipais (1997 e 2002) 
Em todo o Brasil, o processo de municipalização é evidente. Em todos os estados houve aumento da proporção de alunos matriculados em escolas municipais. Transferir para os municípios a gestão das escolas de ensino fundamental é, em tese, uma ideia boa. A municipalização pode adequar a disponibilização de políticas educacionais às necessidades municipais. No entanto, existem evidências de que esse processo ocorreu de forma desordenada e com perda de qualidade. Para o primeiro ciclo do ensino fundamental, o aumento da proporção de alunos matriculados em escolas municipais ocorreu, sobretudo, por meio do aumento do tamanho médio das escolas ${ }^{43}$. Essa constatação sugere que o processo de municipalização ocorreu sem a transferência organizada de escolas de uma rede para outra (SOARES; SOUZA, 2003). Nesse contexto, os municípios passaram a absorver alunos da forma como podiam, sem, contudo dar devida atenção à qualidade da educação oferecida.

Na maioria dos casos, a municipalização não contou com a coordenação entre os governos estaduais e municipais. Aliás, sob a justificativa de que os municípios estariam com recursos adicionais do FUNDEF, muitos estados passaram a não compartilhar a verba do Salário-Educação ${ }^{44}$. Também existem evidências de que os governos estaduais, quando optaram pela política de descentralização de suas escolas, transferiram os piores estabelecimentos para os municípios (BANCO MUNDIAL, 2002). A regra de redistribuição dos recursos do Fundo aguçou a cobiça de alguns prefeitos pelo controle de verbas, o que implicou que muitos municípios expandissem sua atuação no ensino fundamental sem, necessariamente, possuir capacitação institucional para isso.

Com o intuito de avaliar como ocorreu a expansão da gestão dos municípios do ensino fundamental nos municípios brasileiros, dividiu-se a amostra de municípios em dois grupos: os que mais e os que menos se municipalizaram. A base de dados construída permite avaliar que 50\% dos municípios elevaram a proporção de matrículas de $1^{a}$ a $4^{a}$ série em até $21,3 \%$, enquanto que os $50 \%$ restantes elevaram em mais de $21,3 \%$. De tal modo, a amostra foi separada em 2 grupos. O primeiro (Grupo 1) é constituído por municípios que elevaram a proporção de alunos de $1^{a}$ a $4^{a}$ em até $21,3 \%$ entre 1997 e 2002. Já o segundo (Grupo 2) é constituído por municípios que aumentaram a proporção de alunos acima dessa faixa. Dessa forma, é possível avaliar as características e os componentes que mais explicam a municipalização entre os dois grupos.

\footnotetext{
${ }^{43}$ Conforme ressaltado na Revisão de Literatura, o aumento do tamanho médio das escolas municipais é o componente que mais explica a municipalização ocorrida no primeiro ciclo do ensino fundamental. Por outro lado, a criação de escolas municipais em um ritmo maior do que a criação de escolas estaduais é o componente que menos explica a municipalização nesse ciclo.

${ }^{44} 1 / 3$ da verba do Salário Educação é destinado ao FNDE, que financia as atividades do Governo Federal, e 2/3 são destinados aos estados e alguns deles compartilham com seus respectivos municípios.
} 
Como pode ser visto na Tabela 4, o primeiro grupo de municípios, ou seja, aqueles que proporcionalmente menos se municipalizaram, apresentam os piores indicadores educacionais. Em ambos os grupos, ocorreu aumento do número médio de alunos em escolas municipais, com mudança mais acentuada nos municípios que mais se municipalizaram. É possível observar que enquanto o primeiro grupo de municípios apresentou uma ligeira queda no número médio de alunos por turma, o grupo dos que mais se municipalizaram apresentou aumento nesse indicador de 21 para 24 alunos.

Também se observa que os municípios que mais procuraram expandir as matrículas no ensino fundamental são aqueles que em média no período de 1998 a 2002, perderam recursos com o FUNDEF. Os municípios que em média foram beneficiários dos recursos do Fundo tiveram menor incentivo para absorver maior proporção de alunos do ensino fundamental. Ainda que pudessem angariar recursos adicionais com a expansão, ao menos não estavam perdendo. 
Tabela 4: Estatísticas descritivas dos municípios que mais e menos se municipalizaram

\begin{tabular}{|c|c|c|c|}
\hline Variáveis & Período & Grupo 1 & Grupo 2 \\
\hline Taxa de abandono & Em 1997 & $\begin{array}{c}0,107 \\
(0,002)\end{array}$ & $\begin{array}{c}0,109 \\
(0,002)\end{array}$ \\
\hline Taxa de abandono & Em 2002 & $\begin{array}{c}0,066 \\
(0,001)\end{array}$ & $\begin{array}{l}0,067 \\
(0,001)\end{array}$ \\
\hline Taxa de aprovação & Em 1997 & $\begin{array}{c}0,725^{* * *} * \\
(0,003)\end{array}$ & $\begin{array}{c}0,742 * * * \\
(0,003)\end{array}$ \\
\hline Taxa de aprovação & Em 2002 & $\begin{array}{l}0,781 * * * \\
(0,002)\end{array}$ & $\begin{array}{c}0,796^{* * *} \\
(0,002)\end{array}$ \\
\hline Taxa de reprovação & Em 1997 & $\begin{array}{c}0,168 * * * \\
(0,002)\end{array}$ & $\begin{array}{l}0,149 * * * \\
(0,002)\end{array}$ \\
\hline Taxa de reprovação & Em 2002 & $\begin{array}{c}0,151^{* * *} \\
(0,002)\end{array}$ & $\begin{array}{c}0,135 * * * \\
(0,002)\end{array}$ \\
\hline Taxa de distorção idade-série & Em 1997 & $\begin{array}{c}0,451^{* * *} \\
(0,005)\end{array}$ & $\begin{array}{c}0,432 * * * \\
(0,005)\end{array}$ \\
\hline Taxa de distorção idade-série & Em 2002 & $\begin{array}{c}0,365 * * * \\
(0,004)\end{array}$ & $\begin{array}{c}0,326 * * * \\
(0,003)\end{array}$ \\
\hline $\begin{array}{l}\text { Experiência com } \\
5^{a} \text { a } 8^{a} \text { série }\end{array}$ & Em 1997 & $\begin{array}{c}0,105 * * * \\
(0,004)\end{array}$ & $\begin{array}{c}0,072 * * * \\
(0,003)\end{array}$ \\
\hline $\begin{array}{l}\text { Experiência com } \\
5^{a} \text { a } 8^{a} \text { série }\end{array}$ & Em 2002 & $\begin{array}{c}0,200 * * * \\
(0,005)\end{array}$ & $\begin{array}{c}0,166 * * * \\
(0,005)\end{array}$ \\
\hline $\begin{array}{l}\text { Número de } \\
\text { alunos por }\end{array}$ & Em 1997 & $\begin{array}{c}179,608 * * * \\
(3,198)\end{array}$ & $\begin{array}{c}125,669 * * * \\
(3,027)\end{array}$ \\
\hline escola municipal & Em 2002 & $\begin{array}{c}191,537 * * * \\
(2,821)\end{array}$ & $\begin{array}{c}245,905^{* * * *} \\
\quad(3,083)\end{array}$ \\
\hline $\begin{array}{l}\text { Número médio } \\
\text { de alunos }\end{array}$ & Em 1997 & $\begin{array}{c}23,571^{* * * *} \\
(0,140)\end{array}$ & $\begin{array}{c}21,340 * * * \\
(0,145)\end{array}$ \\
\hline por turma & Em 2002 & $\begin{array}{l}22,669^{* * *} \\
(0,127)\end{array}$ & $\begin{array}{l}24,015^{* * *} \\
(0,115)\end{array}$ \\
\hline $\begin{array}{l}\text { Proporção } \\
\text { de matrículas }\end{array}$ & Em 1997 & $\begin{array}{l}0,729 * * * \\
(0,004)\end{array}$ & $\begin{array}{c}0,402 * * * \\
(0,004)\end{array}$ \\
\hline municipais & Em 2002 & $\begin{array}{c}0,762 \\
(0,005)\end{array}$ & $\begin{array}{c}0,768 \\
(0,004)\end{array}$ \\
\hline $\begin{array}{l}\text { Proporção } \\
\text { de escolas }\end{array}$ & Em 1997 & $\begin{array}{c}0,855^{* * *} * \\
(0,003)\end{array}$ & $\begin{array}{c}0,689 * * * \\
(0,005)\end{array}$ \\
\hline municipais & Em 2002 & $\begin{array}{c}0,848^{* * * *} \\
(0,003)\end{array}$ & $\begin{array}{c}0,817 * * * \\
(0,004)\end{array}$ \\
\hline $\begin{array}{l}\text { Proporção de escolas estaduais } \\
\text { descentralizadas }\end{array}$ & Entre 1996 e 2002 & $\begin{array}{c}0,107 * * * \\
(0,005)\end{array}$ & $\begin{array}{c}0,245^{* * * *} \\
(0,006)\end{array}$ \\
\hline $\begin{array}{l}\text { Proporção de } \\
\text { beneficiários do FUNDEF }\end{array}$ & Entre 1998 e 2002 & $\begin{array}{c}0,679 * * * \\
(0,009)\end{array}$ & $\begin{array}{c}0,519 * * * \\
(0,010)\end{array}$ \\
\hline Renda per capita (em R\$) & Censo demográfico de 2000 & $\begin{array}{c}160,741 * * * \\
(1,919)\end{array}$ & $\begin{array}{l}172,437 * * * \\
(1,842)\end{array}$ \\
\hline $\begin{array}{l}\text { Proporção de municípios } \\
\text { pobres }\end{array}$ & Censo demográfico de 2000 & $\begin{array}{c}0,523 * * * \\
(0,010)\end{array}$ & $\begin{array}{c}0,480 * * * \\
(0,010)\end{array}$ \\
\hline
\end{tabular}

${ }^{a} O$ Grupo 1 é constituído por municípios que aumentaram a proporção de matrículas municipais em até $21,3 \%$ (mediana do aumento da proporção de matrículas de $1^{a}$ e $4^{a}$ série em escolas municipais) entre 1997 e 2002.

${ }^{\mathrm{b}} \mathrm{O}$ Grupo 2 é constituído por municípios que aumentaram a proporção de matrículas em mais de $21,3 \%$.

${ }^{\mathrm{c}}$ A hipótese nula do teste de médias realizado consiste em $\mu_{1}=\mu_{2}$, em que $\mu_{1}$ é a média da variável no Grupo 1 e $\mu_{2}$ é a média da variável no Grupo 2. Para maioria das variáveis apresentadas, essa hipótese é rejeitada a $1 \%$ de significância.

${ }^{\mathrm{d}}$ Os municípios foram classificados como pobres se apresentavam, em 2000, renda per capita inferior a um salário mínimo $(\mathrm{R} \$ 151,00)$.

$* * *$ significante a $1 \%, * *$ significante a $5 \%$ e $*$ significante a $10 \%$ 
Quanto à descentralização das escolas estaduais, o Grupo 2 é constituído por municípios que descentralizaram em média $24,5 \%$ das escolas estaduais enquanto o Grupo 1 descentralizou em média 10,7\%. A baixa proporção de escolas descentralizadas nos dois grupos confirma as evidências encontradas por Soares e Souza (2003) de que a municipalização não constituiu uma transferência organizada entre os alunos da rede estadual para a municipal.

Em segundo lugar, o fato de a descentralização ter sido mais intensa nos municípios do Grupo 2 é condizente com a hipótese que esses municípios, por estarem perdendo recursos com o FUNDEF, apresentavam os maiores incentivos para expandirem suas participações no ensino fundamental. Ocorre que o fato de a descentralização ter sido mais intensa em municípios que apresentam melhores indicadores educacionais e níveis mais elevados de renda per capita sugere que esses entes federativos poderiam estar mais bem preparados para absorver as escolas estaduais. Esse argumento baseia-se no fato de que por trás de maiores rendas per capitas estão populações melhor instruídas e com maior destreza em exigir seus direitos (BARDHAN; MOOKHERJEE, 2005).

O processo organizado de transferência de alunos entre redes pressupõe habilidade técnica e capacitação institucional dos municípios. Aumentar o tamanho médio das escolas simplesmente por meio do aumento do tamanho das turmas, ou por meio do aumento do número de turmas é um processo mais rápido e requer menor montante de recursos. Consequentemente, espera-se que a municipalização como um todo apresente efeitos negativos. Por outro lado, a depender do contexto em que foi empregada, espera-se que a troca de gestão de escolas dos estados para os municípios apresente efeitos positivos.

A análise mais detalhada dos dados permite identificar 3.600 municípios que não apresentaram nenhuma escola estadual descentralizada. Mais um indicativo de que a municipalização observada no primeiro ciclo do ensino fundamental ocorreu principalmente por meio do aumento do tamanho médio das escolas. Para os demais municípios, é possível separá-los entre os que descentralizaram ${ }^{45}$ :

- menos de $20 \%$ das escolas estaduais;

- entre $20 \%$ e $40 \%$ das escolas estaduais;

- entre $40 \%$ e $60 \%$ das escolas estaduais;

\footnotetext{
${ }^{45}$ Para cada município, calculou-se a proporção de escolas descentralizadas entre 1996 e 2002.
} 
- entre $60 \%$ e $80 \%$ das escolas estaduais; e

- entre $80 \%$ e $100 \%$ das escolas estaduais.

O número de municípios por faixa de descentralização é de: 303, 460, 575, 374 e 248, respectivamente. Esse critério, por sua vez, permite identificar os municípios que de fato adotaram políticas de municipalização baseadas na descentralização de escolas estaduais. Para evitar possível viés de seleção na análise, restringe-se a amostra as escolas localizadas em municípios que apresentam pelo menos uma escola descentralizada. De tal modo, a análise do impacto da descentralização está restrita às cinco faixas de descentralização definidas anteriormente e acompanham-se as escolas descentralizadas a partir de $1998^{46}$.

A Tabela 5 apresenta a proporção de municípios por estado ${ }^{47}$ em cada uma das 5 faixas de descentralização definidas. A primeira coluna representa a proporção de municípios que não descentralizaram nenhuma escola estadual.

\footnotetext{
${ }^{46}$ Como a descentralização não foi uma política compulsória, na base de dados existem escolas descentralizadas em 1999, em 2000 e em 2001.

${ }^{47}$ Não foi possível acompanhar a evolução da descentralização das escolas estaduais em São Paulo. Após serem descentralizadas, as escolas tiveram seus códigos de identificação alterados de modo que não foi possível identificar o número de estabelecimentos descentralizados sem ter acesso a uma base confidencial do INEP. Ademais, é possível perceber que para alguns estados a soma das colunas é superior a 1. Isso ocorre porque no Censos Escolares respondidos entre 1996 e 2002 foram encontrados mais municípios por estado do que o reportado no Censo Demográfico de 2000. Por exemplo, com base no Censo Escolar, foram identificados 133 municípios no estado do Mato Grosso. No entanto, o Censo Demográfico de 2000 informa que o estado tem apenas 126 municípios.
} 
Tabela 5: Concentração da descentralização nos estados brasileiros

\begin{tabular}{|c|c|c|c|c|c|c|}
\hline & $\begin{array}{c}\text { não } \\
\text { desc. } \\
\text { nenhuma escola } \\
\text { estadual }\end{array}$ & $\begin{array}{l}\text { orção de muni } \\
\text { desc. menos } \\
\text { de } 20 \% \\
\text { das escolas } \\
\text { estaduais }\end{array}$ & $\begin{array}{c}\text { ípios por esta } \\
\text { desc. entre } \\
20 \% \text { e } 40 \% \\
\text { das escolas } \\
\text { estaduais }\end{array}$ & $\begin{array}{l}\text { que: } \\
\text { desc. entre } \\
40 \% \text { e } 60 \% \\
\text { das escolas } \\
\text { estaduais }\end{array}$ & $\begin{array}{c}\text { desc. entre } \\
60 \% \text { e } 80 \% \\
\text { das escolas } \\
\text { estaduais }\end{array}$ & $\begin{array}{c}\text { desc. entre } \\
80 \% \text { e } 100 \% \\
\text { das escolas } \\
\text { estaduais }\end{array}$ \\
\hline Acre & 0,41 & 0,41 & 0,05 & 0,09 & 0,05 & 0,00 \\
\hline Alagoas & 0,89 & 0,03 & 0,01 & 0,04 & 0,02 & 0,01 \\
\hline Amapá & 0,56 & 0,44 & 0,00 & 0,00 & 0,00 & 0,00 \\
\hline Amazonas & 0,81 & 0,08 & 0,08 & 0,02 & 0,02 & 0,00 \\
\hline Bahia & 0,15 & 0,03 & 0,21 & 0,33 & 0,21 & 0,06 \\
\hline Ceará & 0,66 & 0,11 & 0,11 & 0,10 & 0,01 & 0,00 \\
\hline Espírito Santo & 0,08 & 0,23 & 0,21 & 0,17 & 0,17 & 0,14 \\
\hline Goiás & 0,78 & 0,07 & 0,06 & 0,06 & 0,02 & 0,02 \\
\hline Maranhão & 0,90 & 0,01 & 0,05 & 0,04 & 0,00 & 0,00 \\
\hline Mato Grosso & 0,97 & 0,03 & 0,02 & 0,01 & 0,03 & 0,00 \\
\hline Mato Grosso do Sul & 1,00 & 0,00 & 0,00 & 0,00 & 0,00 & 0,00 \\
\hline Minas Gerais & 0,33 & 0,07 & 0,17 & 0,20 & 0,12 & 0,11 \\
\hline Pará & 0,32 & 0,10 & 0,03 & 0,13 & 0,22 & 0,20 \\
\hline Paraíba & 0,97 & 0,01 & 0,02 & 0,00 & 0,00 & 0,00 \\
\hline Paraná & 0,88 & 0,03 & 0,02 & 0,04 & 0,01 & 0,03 \\
\hline Pernambuco & 0,76 & 0,08 & 0,09 & 0,05 & 0,02 & 0,01 \\
\hline Piauí & 0,71 & 0,04 & 0,05 & 0,11 & 0,02 & 0,07 \\
\hline Rio de Janeiro & 0,51 & 0,21 & 0,14 & 0,13 & 0,01 & 0,01 \\
\hline Rio Grande do Norte & 0,84 & 0,03 & 0,05 & 0,04 & 0,02 & 0,01 \\
\hline Rio Grande do Sul & 0,72 & 0,07 & 0,10 & 0,09 & 0,03 & 0,00 \\
\hline Rondônia & 0,85 & 0,04 & 0,02 & 0,10 & 0,00 & 0,00 \\
\hline Roraima & 0,27 & 0,53 & 0,13 & 0,07 & 0,00 & 0,00 \\
\hline Santa Catarina & 0,16 & 0,04 & 0,09 & 0,22 & 0,32 & 0,17 \\
\hline Sergipe & 0,80 & 0,05 & 0,07 & 0,05 & 0,03 & 0,00 \\
\hline Tocantins & 0,88 & 0,04 & 0,06 & 0,01 & 0,01 & 0,01 \\
\hline
\end{tabular}

${ }^{\text {a }}$ Esta tabela foi construída com base nas escolas descentralizadas entre 1996 e 2002.

Fonte: Censo Escolar

Os estados da Bahia, do Espírito Santo, de Minas Gerais, do Rio de Janeiro e de Santa Catariana concentram a maior proporção de municípios por faixas de descentralização.

A Tabela 6 apresenta o número de escolas descentralizadas por ano nos estados brasileiros. Ainda que o número de estabelecimentos descentralizados seja elevado em alguns estados, os dados da Tabela 5 confirmam que a descentralização não foi um processo aplicado a todas as escolas estaduais. 
Tabela 6: Número de escolas estaduais descentralizadas por ano e por estado

\begin{tabular}{|c|c|c|c|c|c|}
\hline & 1998 & 1999 & 2000 & 2001 & 2002 \\
\hline Acre & 10 & 10 & 7 & 13 & 28 \\
\hline Alagoas & 11 & 7 & 1 & 0 & 1 \\
\hline Amapá & 4 & 2 & 2 & 4 & 0 \\
\hline Amazonas & 1 & 0 & 0 & 0 & 3 \\
\hline Bahia & 1.363 & 49 & 19 & 38 & 5 \\
\hline Ceará & 48 & 14 & 8 & 4 & 2 \\
\hline Espírito Santo & 1.042 & 20 & 18 & 13 & 3 \\
\hline Goiás & 35 & 0 & 44 & 27 & 6 \\
\hline Maranhão & 3 & 1 & 0 & 1 & 22 \\
\hline Mato Grosso & 10 & 12 & 0 & 0 & 1 \\
\hline Mato Grosso do Sul & 0 & 0 & 0 & 0 & 0 \\
\hline Minas Gerais & 1.344 & 43 & 8 & 2 & 0 \\
\hline Pará & 871 & 144 & 326 & 91 & 26 \\
\hline Paraíba & 5 & 0 & 0 & 1 & 0 \\
\hline Paraná & 26 & 21 & 5 & 2 & 31 \\
\hline Pernambuco & 64 & 10 & 38 & 7 & 0 \\
\hline Piauí & 61 & 27 & 6 & 16 & 4 \\
\hline Rio de Janeiro & 79 & 20 & 9 & 37 & 8 \\
\hline Rio Grande do Norte & 11 & 2 & 0 & 18 & 21 \\
\hline Rio Grande do Sul & 89 & 59 & 2 & 2 & 3 \\
\hline Rondônia & 3 & 3 & 130 & 11 & 2 \\
\hline Roraima & 7 & 16 & 1 & 4 & 38 \\
\hline Santa Catarina & 21 & 20 & 25 & 17 & 16 \\
\hline Sergipe & 0 & 13 & 2 & 10 & 6 \\
\hline Tocantins & 17 & 18 & 8 & 0 & 2 \\
\hline
\end{tabular}

Fonte: Censo Escolar

A Tabela 7 apresenta a proporção de municípios e a proporção da população por eles representada dentro de cada estado da amostra de dados constituída para avaliar o impacto da descentralização das escolas estaduais. 
Tabela 7: Proporção de municípios e da população estudada por estado para avaliação do impacto da descentralização

\begin{tabular}{lcc}
\hline Estados & Municípios & População \\
\hline Acre & 0,50 & 0,33 \\
Alagoas & 0,07 & 0,05 \\
Amapá & 0,13 & 0,02 \\
Amazonas & 0,06 & 0,02 \\
Bahia & 0,83 & 0,81 \\
Ceará & 0,26 & 0,26 \\
Espírito Santo & 0,86 & 0,70 \\
Goiás & 0,17 & 0,44 \\
Maranhão & 0,09 & 0,08 \\
Mato Grosso & 0,06 & 0,27 \\
Minas Gerais & 0,63 & 0,59 \\
Pará & 0,61 & 0,51 \\
Paraíba & 0,02 & 0,04 \\
Paraná & 0,09 & 0,31 \\
Pernambuco & 0,23 & 0,42 \\
Piauí & 0,20 & 0,16 \\
Rio de Janeiro & 0,34 & 0,26 \\
Rio Grande do Norte & 0,11 & 0,08 \\
Rio Grande do Sul & 0,20 & 0,15 \\
Rondônia & 0,10 & 0,29 \\
Roraima & 0,67 & 0,85 \\
Santa Catarina & 0,08 & 0,13 \\
Sergipe & 0,17 & 0,12 \\
Tocantins & 0,08 & 0,14 \\
\hline Fonte: Censo Escolar & Cens & \\
\hline
\end{tabular}

Fonte: Censo Escolar e Censo Demográfico

Em primeiro lugar, com base no painel de municípios, este trabalho analisará os impactos do aumento da proporção de alunos de $1^{a}$ a $4^{a}$ série matriculados em escolas municipais. Em segundo lugar, com base na amostra de municípios que descentralizaram escolas estaduais, serão investigados os efeitos desse processo nos indicadores de rendimento e de distorção idadesérie auferidos por alunos de $1^{a}$ a $4^{a}$ série. 


\section{METODOLOGIA}

No que concerne à troca de gestão de algumas escolas estaduais, hipoteticamente, deseja-se comparar os indicadores educacionais das escolas descentralizadas com os que seriam por elas auferidos caso não tivessem sido transferidas à gestão municipal. Dessa forma, o efeito da descentralização seria obtido por meio da comparação dos indicadores em ambas as situações, com e sem descentralização. Contudo, o problema central da avaliação do impacto de qualquer programa está na não observação dos resultados das unidades participantes em sua situação contrafactual de não participação.

Nesse contexto, o método de avaliação a ser escolhido deve considerar a natureza da questão a ser respondida, o mecanismo pelo qual algumas escolas foram alocadas no grupo dos estabelecimentos descentralizados, assignment rule, e o tipo e a qualidade dos dados disponíveis (BLUNDELL; DIAS, 2002). Para a escolha do modelo que melhor se adapte à descentralização ocorrida em alguns municípios brasileiros, inicia-se a discussão com o Modelo de Resultados Potenciais.

Para facilitar a compreensão, considera-se um modelo sem variáveis de controle. Seja $y_{i}$ a variável resultado sobre a qual se deseja estudar o impacto de determinado programa, e $d_{i}$ uma dummy igual a 1 se a unidade de observação $i$ recebeu o tratamento e igual a 0 caso contrário. Dessa maneira, as unidades para as quais $d_{i}=1$ constituem o grupo de tratamento e para as quais $d_{i}=0$ o grupo de comparação ${ }^{48}$. Os resultados potenciais para os dois grupos são dados por $y_{i}^{1}$ e $y_{i}^{0}$ para os casos em que $d_{i}=1$ e $d_{i}=0$, respectivamente:

$$
\begin{aligned}
& y_{i}^{1}=\beta+\alpha_{i}+v_{i} \\
& y_{i}^{0}=\beta+v_{i}
\end{aligned}
$$

Em que $\beta$ é o intercepto, $\alpha_{i}$ é o efeito do tratamento para a unidade $i$ e $v_{i}$ é um erro não observável. Assim, infere-se que o resultado para qualquer $i$ pode ser obtido por meio da seguinte equação:

$$
y_{i}=\beta+\alpha_{i} d_{i}+v_{i}
$$

\footnotetext{
${ }^{48}$ De acordo com o trabalho Heckman e Hotz (1989), em situações experimentais, o grupo de comparação é constituído por unidades de observação aceitas no programa, mas posteriormente aleatorizadas a não participarem. Especificamente nesse caso, o grupo de comparação é denominado grupo de controle. No entanto, em situações não experimentais, o grupo de comparação consiste em unidades de observação julgadas comparáveis com às unidades participantes.
} 
Na melhor hipótese, a seleção das unidades entre os grupos de tratamento e comparação é feita de forma aleatória, o que constitui denominado experimento social. De tal modo, pode-se assumir que a distribuição das características observáveis e não observáveis seja a mesma e a única diferença sistemática entre os grupos consista na exposição ao tratamento. Nesses casos, a aleatorização corresponde a duas hipóteses:

$$
\begin{aligned}
& E\left[v_{i} \mid d_{i}=1\right]=E\left[v_{i} \mid d_{i}=0\right] \\
& E\left[\alpha_{i} \mid d_{i}=1\right]=E\left[\alpha_{i} \mid d_{i}=0\right]
\end{aligned}
$$

Entretanto, na maior parte dos casos a alocação entre os grupos é feita pelo administrador do programa ou pelas próprias unidades participantes. Suponha que a participação dependa de informações, observáveis ou não, disponíveis até o momento da decisão, de modo que exista a seguinte regra de seleção:

$$
d_{i}=\left\{\begin{array}{l}
1 \text { se } d_{i}^{*} \geq 0 \\
0 \text { c.c. }
\end{array}\right.
$$

Em que $d_{i}^{*}$ é uma função de características observáveis, $Z_{i}$, e não observáveis, $v_{i}$ :

$$
d_{i}^{*}=g\left(Z_{i}, v_{i}\right)
$$

Quando o efeito do tratamento é homogêneo, $\alpha_{i}=\alpha$ na equação (2), existe um único impacto para o programa e ele é o mesmo independente do grupo de tratamento escolhido. Para tratamentos heterogêneos, o efeito da exposição varia conforme os indivíduos alocados em cada um dos grupos, ou seja, os grupos de tratamento e comparação são diferentes a tal ponto que se o tratamento fosse aplicado a esse segundo grupo revelaria um impacto diferente. Comumente o que se busca identificar é o efeito médio do tratamento, average treatment effect (ATE), e efeito médio do tratamento nos tratados, average treatment effect on treated (ATT).

Esses parâmetros podem ser escritos respectivamente como:

$$
\begin{gathered}
\alpha^{A T E}=E\left(\alpha_{i}\right) \\
\alpha^{A T T}=E\left(\alpha_{i} \mid d_{i}=1\right)=E\left(\alpha_{i} \mid g\left(Z_{i}, \nu_{i}\right) \geq 0\right)
\end{gathered}
$$

Dessa forma, é possível perceber que em tratamentos homogêneos o ATE e o ATT são iguais e em tratamentos heterogêneos são distintos. Para verificar como esses parâmetros podem ser 
estimados, a equação (2) deve ser reescrita com a soma e a subtração de $\alpha^{A T E} d_{i}$ :

$$
\begin{aligned}
& y_{i}=\beta+\alpha^{A T E} d_{i}+\left(v_{i}+d_{i}\left(\alpha_{i}-\alpha^{A T E}\right)\right) \\
& y_{i}=\beta+\alpha^{A T E} d_{i}+\varepsilon_{i}
\end{aligned}
$$

Em que $\varepsilon_{i}=\left(v_{i}+d_{i}\left(\alpha_{i}-\alpha^{A T E}\right)\right)$. Existe viés de seleção se a variável que determina o tratamento, $d_{i}$, e o termo de erro, $\varepsilon_{i}$, são correlacionados. Em outras palavras, $\varepsilon_{i}$ pode ser tanto correlacionado com variáveis observáveis que determinam o tratamento, $Z_{i}$, quanto com características não observáveis, $v_{i}$. Desse modo, determina-se seleção não aleatória em variáveis observáveis e não observáveis, respectivamente.

Nesse contexto, quando o viés de seleção decorre da relação entre $v_{i}$ e $d_{i}$, existe seleção nos resultados não tratados, na medida em que indivíduos com diferentes características não observáveis podem ser mais ou menos suscetíveis a receberem tratamento. Se, por outro lado, a seleção advir da relação entre $d_{i}$ e $\alpha_{i}$ existe seleção nos ganhos esperados. Dessa forma, a escolha em participar do programa é determinada pelo fato de os retornos esperados com e sem tratamento serem diferentes.

Independente do efeito do tratamento ser homogêneo ou heterogêneo, pelo fato de a alocação dos indivíduos entre os grupos de tratamento e comparação ser majoritariamente não aleatória, o problema do viés de seleção persiste e implica que o estimador de Mínimos Quadrados Ordinários (MQO) aplicado à equação (2) seja inconsistente. Nesses casos, é possível afirmar que os resultados médios dos dois grupos diferem mesmo na ausência de tratamento (HECKMAN; HOTZ, 1989):

$$
E\left[Y_{i}^{*} \mid d_{i}=1\right] \neq E\left[Y_{i}^{*} \mid d_{i}=0\right]
$$

Em que $Y_{i}^{*}$ é o resultado esperado para os grupos de tratamento e comparação na ausência de tratamento. Portanto, $E\left[\varepsilon_{i} \mid d_{i}\right] \neq 0$ na equação (9) é equivalente ao viés de seleção explicitado na equação (10). De tal modo, pode-se subestimar ou superestimar o impacto do tratamento, a depender do impacto que as variáveis omitidas apresentarem na variável dependente e da sua correlação com o recebimento do tratamento.

Em um contexto de tratamento homogêneo, o viés de seleção ocorre somente por meio da correlação entre $v_{i}$ e $d_{i}$. Nesse caso, $\alpha_{i}=\alpha$ para toda população e a equação (2) se reduz a:

$$
y_{i}=\beta+\alpha d_{i}+v_{i}
$$


Em que $\alpha$ é o impacto do tratamento para qualquer indivíduo e, portanto, igual a $\alpha^{A T E}$. O estimador de MQO permite identificar:

$$
E\left[\hat{\alpha}^{O L S}\right]=\alpha+E\left[\mathrm{v}_{i} \mid d_{i}=1\right]-E\left[\mathrm{v}_{i} \mid d_{i}=0\right]
$$

Dessa maneira, ainda que a disponibilidade de dados seja apenas em cross section, é possível obter um estimador consistente para o efeito médio do tratamento, ATE, se $v_{i}$ e $d_{i}$ forem não correlacionados.

Sob ocorrência de tratamento heterogêneo, o viés de seleção é mais severo, na medida em que a seleção pode decorrer tanto dos resultados não tratados quanto dos ganhos esperados. Nesse caso, a estimação da equação (9) por MQO possibilita identificar:

$$
E\left[\hat{\alpha}^{O L S}\right]=\alpha+E\left[\alpha_{i}-\alpha^{A T E} \mid d_{i}=1\right]+E\left[v_{i} \mid d_{i}=1\right]-E\left[v_{i} \mid d_{i}=0\right]
$$

Note que o primeiro termo, $\alpha+E\left[\alpha_{i}-\alpha^{A T E} \mid d_{i}=1\right]$, é igual ao ATT. Consequentemente, mantida a hipótese de que $v_{i}$ e $d_{i}$ são não correlacionados, é possível obter um estimador consistente para o efeito do tratamento nos tratados ainda que $d_{i}$ e $\alpha_{i}$ sejam correlacionados. Em experimentos sociais, por exemplo, as hipóteses apresentadas nas equações (3) e (4) são suficientes para garantir que $E\left[\hat{\alpha}^{O L S}\right]=\alpha$, ou seja, nesse caso é possível estimar o efeito médio do tratamento e o estimador obtido é não viesado e consistente.

Por outro lado, em tratamentos não aleatórios é difícil se esperar que $\varepsilon_{i}$ e $d_{i}$ sejam não correlacionados. Uma das maneiras de atenuar o viés de seleção é trabalhar com regressões multivariadas e, dessa forma, controlar as diferenças observáveis entre os grupos de tratamento e comparação. Entretanto, essa forma de atenuação de viés de seleção não elimina a seleção decorrente de variáveis não observáveis.

Nesse contexto, a disponibilidade de dados em painel possibilita empregar a metodologia de diferença em diferenças que, por sua vez, permite controlar características fixas e não observáveis que estejam possivelmente correlacionadas com o recebimento do tratamento. Considera-se que cada unidade $i$ é observada antes, $t_{0}$, e depois, $t_{1}$, da implantação de determinado programa sobre o qual se deseja mensurar o impacto. Seja $d_{i t}$ uma dummy igual a 1 para as unidades do grupo de tratamento depois da implantação do programa. É possível reescrever a equação (2) da seguinte forma:

$$
y_{i t}=\beta+\alpha_{i} d_{i t}+v_{i t}
$$


Em que $E\left[v_{i t} \mid d_{i}, t\right]=E\left[\eta_{i} \mid d_{i}\right]+\lambda_{t}$. Define-se $\eta_{i}$ um efeito fixo não observado e $\lambda_{t}$ um choque macro agregado. A consistência do estimador de diferença em diferenças está baseada nas hipóteses de que a tendência no tempo para os grupos de tratamento e comparação é a mesma e que o viés de seleção resultante da correlação entre $d_{i t}$ e $v_{i t}$ é eliminado por meio da diferenciação, tal que:

$$
E\left[v_{i t_{1}}-v_{i t_{0}} \mid d_{i}=1\right]=E\left[v_{i t_{1}}-v_{i t_{0}} \mid d_{i}=0\right]=E\left[v_{i t_{1}}-v_{i t_{0}}\right]
$$

Para os grupos de tratamento e comparação antes, $t_{0}$, e depois do tratamento, $t_{1}$, é possível escrever:

$$
E\left[y_{i t} \mid d_{i}, t\right]=\left\{\begin{array}{l}
\beta+E\left[\alpha_{i} \mid d_{i}=1\right]+E\left[\eta_{i} \mid d_{i}=1\right]+\lambda_{t} \text { se } d_{i}=1 \text { e } t=t_{1} \\
\beta+E\left[\eta_{i} \mid d_{i}=1\right] \text { se } d_{i}=1 \text { e } t=t_{0} \\
\beta+E\left[\eta_{i} \mid d_{i}=0\right]+\lambda_{t} \text { se } d_{i}=0 \text { e } t=t_{1} \\
\beta+E\left[\eta_{i} \mid d_{i}=0\right] \text { se } d_{i}=0 \text { e } t=t_{0}
\end{array}\right.
$$

Dessa forma, o efeito do tratamento para os tratados, $\alpha^{A T T}=E\left[\alpha_{i} \mid d_{i}=1\right]$, pode ser obtido por meio da aplicação de diferenças sequenciais:

$$
\begin{array}{r}
\alpha^{A T T}=\left\{E\left[y_{i t} \mid d_{i}=1, t=t_{1}\right]-E\left[y_{i t} \mid d_{i}=1, t=t_{0}\right]\right\}- \\
\left\{E\left[y_{i t} \mid d_{i}=0, t=t_{1}\right]-E\left[y_{i t} \mid d_{i}=0, t=t_{0}\right]\right\}
\end{array}
$$

A contrapartida amostral da equação (17) é:

$$
\hat{\alpha}^{D I D}=\left[\overline{y_{t_{1}}^{1}}-\overline{y_{t_{0}}^{1}}\right]-\left[\overline{y_{t_{1}}^{0}}-\overline{y_{t_{0}}^{0}}\right]
$$

O estimador de diferença em diferenças subtrai as variações médias dos grupos de tratamento e comparação, o que elimina tendências que sejam comuns aos dois grupos e fatores fixos não observáveis.

A hipótese de que as tendências dos grupos de tratamento e comparação são as mesmas pode ser testada por meio das suas respectivas tendências no período pré-tratamento. Ainda que variáveis independentes sejam adicionadas na análise com intuito de controlar as diferenças entre os grupos, se possível, deve-se escolher um grupo de comparação tal que as características observáveis sejam próximas as apresentadas pelo grupo de tratamento. Espera-se que grupos com características parecidas reajam de forma semelhante às influências externas. 
É importante ressaltar que a diferenciação elimina apenas a possibilidade de viés de seleção decorrente da correlação entre o efeito fixo, $\eta_{i}$, e a dummy de tratamento, $d_{i}$. É possível que existam outros fatores não observáveis que estejam correlacionados com $d_{i}$. Além disso, o método não resolve o problema de seleção resultante dos ganhos esperados, de forma que comumente o parâmetro estimado será o efeito médio do tratamento nos tratados, ATT.

Quando $t=2$ é possível verificar que o estimador de diferença em diferenças é o estimador de primeiras diferenças comumente aplicado aos dados em painel na presença de efeitos fixos. Assim, uma maneira alternativa para obter $\hat{\alpha}^{D I D}$ é aplicar a primeira diferença na equação (14) (BLUNDELL; DIAS, 2002):

$$
y_{i t_{1}}-y_{i t_{0}}=\alpha_{i} d_{i t}+\left(\lambda_{t_{1}}-\lambda_{t_{0}}\right)+\left(o_{i t_{1}}-o_{i t_{0}}\right)
$$

Em que $o_{i t}$ representa os choques idiossincráticos temporários. Por meio da equação (19) é mais fácil perceber que a consistência do estimador de diferença em diferenças está baseada na hipótese de que tais choques são não correlacionados com a variável que determina tratamento, $d_{i t}$.

Para pequenos intervalos de tempo, é possível acreditar que a maior parte das características não observáveis sejam constantes, de modo que a metodologia apresentada consiga eliminá-las. No entanto, em comparação à utilização de dados em cross section, o estimador de diferença em diferenças pode implicar duas outras formas de viés. A primeira decorre do fato de que variáveis dependentes analisadas poderiam estar em trajetória ascendente ou descendente mesmo na ausência de tratamento. A segunda resulta do fato de que é possível que outras políticas, simultâneas ao tratamento, afetem os grupos de tratamento e comparação de maneira diferente.

Nesse contexto, é importante escolher um grupo de comparação que emule os resultados que seriam obtidos pelo grupo de tratamento na ausência de participação no programa. Também é fundamental adicionar variáveis que possam explicar a alocação dos indivíduos em cada um dos grupos e variáveis que os afetem de forma diferente. O maior problema não é os grupos de tratamento e comparação serem diferentes, mas sim essas diferenças estarem correlacionadas com as variáveis dependentes analisadas. Também é necessário ponderar o efeito de outras políticas que tenham ocorrido simultaneamente àquela que se deseja avaliar o impacto. $\mathrm{O}$ atendimento das hipóteses apresentadas fornece evidências de que o estimador de diferença em diferenças é consistente. 


\subsection{Modelos propostos}

Inicialmente, com intuito de avaliar o impacto de todo processo de municipalização, propõe-se a estimação do seguinte modelo por efeitos fixos e por primeiras diferenças ${ }^{49}$ :

$$
y_{j t}=\lambda_{t}+z_{j t} \alpha+x_{j t} \gamma+\eta_{j}+v_{j t}, t=1997,1998 \ldots \text { e } 2002
$$

Em que $y_{j t}$ constitui os indicadores de rendimento e distorção idade-série dos alunos de $1^{a}$ a $4^{a}$ série do município $j$ no ano $t, \lambda_{t}$ são dummies de ano, $z_{j t}$ são as características médias das escolas do município $j, x_{j t}$ são variáveis de controle do município $j, \eta_{j}$ é o efeito fixo do município $j$ e $v_{j t}$ é o termo de erro idiossincrático.

Nesse caso, pelo fato de o FUNDEF constituir uma reforma nacional, não é possível estabelecer um grupo de comparação e empregar a metodologia de diferença em diferenças para avaliar os seus impactos, dentre eles a municipalização induzida. Por outro lado, ainda que a omissão de variáveis relevantes constitua um problema, não é necessário preocupar-se especificamente com viés de seleção.

Espera-se que efeito fixo, $\eta_{j}$, seja correlacionado com os controles utilizados. Muitas variáveis não observáveis como, por exemplo, aptidão dos professores, podem estar correlacionadas com as características médias das escolas. Os métodos de estimação propostos, por meio da disponibilidade de dados em painel, permitem que $\eta_{j}$ seja correlacionado com $z_{j t}$ e $x_{j t}$ sem prejuízo para consistência dos estimadores. Dessa forma, ainda que a estimação por primeiras diferenças e por efeitos fixos impossibilite estimar o impacto de variáveis que sejam constantes no tempo ${ }^{50}$, sua estimação é mais robusta do que o uso de efeitos aleatórios.

\footnotetext{
${ }^{49}$ Em primeiro lugar, se o erro idiossincrático, $v_{j t}$, for não correlacionado com as variáveis explicativas utilizadas, os estimadores de primeiras diferenças e de efeitos fixos são consistentes. Nesse caso, as estimativas obtidas por ambas as metodologias são próximas e a escolha entre os estimadores depende da estrutura de correlação dos erros. Nesse sentido, se os erros, $v_{i t}$, são serialmente não correlacionados a estimação por efeito fixo é mais eficiente que por primeiras diferenças. Se por outro lado $v_{i t}$ seguir um passeio aleatório, de forma que $\Delta v_{i t}$ seja serialmente não correlacionado, a estimação por primeiras diferenças é mais eficiente. No entanto, é mais provável que os erros não apresentem correlação exatamente igual a 0 ou igual a 1. Dessa forma, se a correlação entre $\Delta v_{i t}$ for negativa, os estimadores de efeitos fixos tendem a ser mais eficientes. Em segundo lugar, se as estimativas de ambas as metodologias destoarem muito, existem evidências de que $v_{i t}$ é correlacionado com as variáveis explicativas utilizadas. Nesses casos, o viés do assimptótico do estimador de efeitos fixos é, em geral, menor (WOOLDRIDGE, 2002).

${ }^{50}$ Não é possível diferenciar variáveis constantes no tempo do efeito fixo, $\eta_{j}$.
} 
Para a estimação por efeitos fixos, deve-se subtrair da equação (20) a sua média ao longo do tempo, de modo a eliminar o efeito fixo $\eta_{j}$. Assim, para cada unidade de observação $j$ é possível escrever:

$$
\ddot{y}_{j t}=\delta_{t}+\ddot{z}_{j t} \alpha+\ddot{x}_{j t} \gamma+\ddot{v}_{j t}, t=1997,1998 \ldots . \text { e } 2002
$$

Em que $\ddot{y}_{j t}=y_{j t}-\bar{y}_{j t}$ são os dados temporais reduzidos de $y$ e, de maneira análoga, $z, x$ e $v . \delta_{t}$ são as novas dummies de ano.

Por meio da estimação por primeiras diferenças também é possível eliminar $\eta_{j}$. Deve-se subtrair da equação (20) no período $t$ os seus valores em $t-1$. Dessa forma, para cada unidade de observação $j$ é possível escrever:

$$
\Delta y_{j t}=\delta_{t}+\Delta z_{j t} \alpha+\Delta x_{j t} \gamma+\Delta v_{j t}, t=1997,1998 \ldots \text { e } 2002
$$

Em que $\Delta y_{j t}=y_{j t}-y_{j t-1}$ é a variação temporal de $y$ e, de maneira análoga, $z, x$ e v.

Seja $w_{j}$ a matriz de controles com as características das escolas, $z_{j t}$, e do município $j, x_{j t}$, para todo o período estudado e $w_{j t}$ o vetor com todos os controles do município $j$ no ano $t$. A estratégia de identificação por efeitos fixos está baseada nas hipóteses de que $E\left[\ddot{v}_{j t}^{\prime} \ddot{w}_{j}\right]=0$ e que o posto $\sum_{t=1}^{T} E\left[\ddot{w}_{j t}^{\prime} \ddot{w}_{j t}\right]$ é completo. Ou seja, a consistência do estimador esta baseada na hipótese de que os controles adicionados são suficientes para garantir que o erro idiossincrático, $v_{j t}$, não apresente relação com nenhuma variável independente em qualquer $t$. Além disso, o estimador de efeitos fixos só é identificado se não houver nenhuma variável que seja constante no tempo para todas as unidades de cross section.

A estimação por primeiras diferenças está baseada nas hipóteses de que $E\left[\Delta v_{j t}^{\prime} \Delta w_{j}\right]=0$ e que o posto $\sum_{t=1}^{T} E\left[\Delta w_{j t}^{\prime} \Delta w_{j t}\right]$ é completo. De tal modo, a consistência desse estimador depende de $\Delta v_{j t}$ ser não correlacionado com os controles utilizados em qualquer $t$ e a sua identificação está condicionada a variação temporal das variáveis independentes em pelo menos alguma unidade de cross section.

Semelhantemente aos trabalhos empíricos já realizados, as especificações apresentadas possibilitam analisar os efeitos da migração de rede (aumento da proporção de alunos de $1^{a}$ a $4^{a}$ série matriculados em escolas municipais) e expansão de rede (aumento da proporção de escolas municipais de $1^{a}$ a $4^{a}$ no total de escolas). A inclusão de características médias das escolas 
e dos municípios permite controlar grande parte dos fatores que estejam correlacionados com a municipalização e com os indicadores educacionais avaliados. Ademais, também são incluídas variáveis que, até então, não haviam sido empregadas na literatura empírica. Por exemplo, se o município é "beneficiário" ou "doador" de recursos para o FUNDEF e a maior rigidez de gasto que também é imposta aos governos estaduais.

Consequentemente, acredita-se isolar o efeito da municipalização de modo a avaliar os verdadeiros impactos da expansão da gestão municipal no primeiro ciclo do ensino fundamental e da maior rigidez de gasto imposta aos municípios, ou seja, verificar se a municipalização de fato foi um processo desordenado e com perda de qualidade.

Em segundo lugar, com intuito de analisar um componente específico de todo o processo de municipalização, a descentralização de algumas escolas estaduais, adota-se a metodologia de diferença em diferenças (WOOLDRIDGE, 2007a). As escolas descentralizadas entre 1998 e 2002 constituem o grupo de tratamento. Propõe-se que as escolas que permaneceram sob gestão estadual no período constituam o grupo de comparação. Dessa forma, os indicadores educacionais das escolas estaduais são as estimativas dos verdadeiros contrafactuais das escolas descentralizadas, ou seja, o que teria acontecido com esses estabelecimentos caso não tivessem sido descentralizados.

A Tabela 8 apresenta o número de escolas nos grupos de tratamento e comparação por faixas de descentralização. A restrição da amostra aos municípios que apresentam pelo menos uma escola em cada um dos grupos possibilita que as escolas descentralizadas e as que permaneceram sob gestão estadual estejam sujeitas às mesmas influências externas.

Tabela 8: Número de escolas nos grupos de tratamento e comparação por faixa de descentralização

\begin{tabular}{lcc}
\hline $\begin{array}{c}\text { Proporção de municípios } \\
\text { que descentralizaram }\end{array}$ & $\begin{array}{c}\text { Grupo de } \\
\text { tratamento }\end{array}$ & $\begin{array}{c}\text { Grupo de } \\
\text { comparação }\end{array}$ \\
\hline Menos que 20\% das escolas & 440 & 3.776 \\
entre 20\% e 40\% das escolas & 922 & 1.709 \\
entre 40\% e 60\% das escolas & 1.674 & 1.255 \\
entre 60\% e 80\% das escolas & 1.544 & 435 \\
Mais que 80\% das escolas & 1.360 & 108 \\
\hline
\end{tabular}

Fonte: Censo Escolar

A Figura 8 apresenta a evolução das taxas de aprovação, reprovação, abandono e distorção idade-série para os grupos de tratamento e comparação. Para o período pré-tratamento, entre 
1996 e 1997, é possível perceber que as tendências de ambos os grupos são similares ${ }^{51}$.
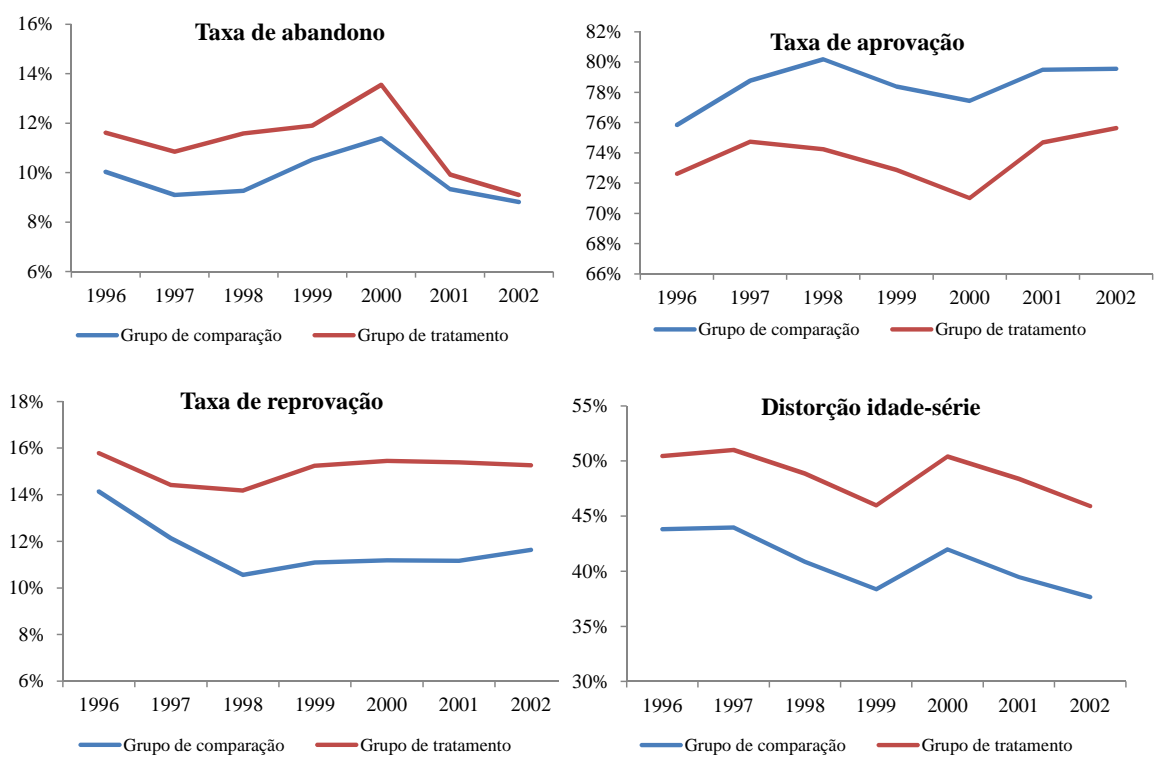

Fonte: Censo Escolar

Figura 8: Indicadores educacionais dos grupos de tratamento e comparação (1996 a 2002)

\footnotetext{
${ }^{51} \mathrm{O}$ grupo de comparação apresenta uma queda mais acentuada na taxa de reprovação.
} 
Ainda que as tendências sejam semelhantes, um dos maiores problemas dessa abordagem é o fato de que os próprios municípios determinaram sua participação no programa. Consequentemente, as diferenças observáveis entre os indicadores de rendimento dos grupos de tratamento e comparação podem decorrer do critério utilizado pelos prefeitos e não da descentralização em si (MADEIRA, 2007). Os grupos de tratamento e comparação podem ser significativamente diferentes e se essas diferenças estiverem relacionadas com as variáveis dependentes analisadas o estimador para a descentralização será inconsistente.

Nesse sentido, por exemplo, escolas descentralizadas podem estar localizadas em regiões mais pobres e, em geral, tais regiões apresentam os piores indicadores educacionais. Portanto, pode-se confundir o efeito da descentralização com o efeito renda (GALIANI; GERTLER; SCHARGRODSKY, 2008). Dessa forma, é importante ponderar os fatores, observáveis e não observáveis, que tenham determinado a descentralização de algumas escolas estaduais.

A Tabela 9 apresenta as características dos grupos de tratamento e comparação. Percebe-se que as escolas descentralizadas apresentam os piores indicadores educacionais, a menor proporção de insumos escolares e estão localizadas em municípios menores e mais pobres. Para que não se confunda o efeito da descentralização com o impacto de tais diferenças nas variáveis dependentes estudadas, uma série de controles, para as escolas e para os municípios em que elas estão localizadas, foram adicionados na análise. Dessa forma, é possível controlar grande parte das diferenças observáveis entre os grupos de tratamento e comparação. 
Tabela 9: Estatísticas descritivas dos grupos de tratamento e comparação antes da descentralização (1997)

\begin{tabular}{|c|c|c|}
\hline & Grupo de comparação & Grupo de tratamento \\
\hline \multicolumn{3}{|l|}{ Indicadores de rendimento } \\
\hline Taxa de abandono & $\begin{array}{c}0,091 * * * \\
(0,001)\end{array}$ & $\begin{array}{c}0,108 * * * \\
(0,001)\end{array}$ \\
\hline Taxa de reprovação & $\begin{array}{c}0,121 * * * \\
(0,001)\end{array}$ & $\begin{array}{c}0,144 * * * \\
(0,002)\end{array}$ \\
\hline Taxa de aprovação & $\begin{array}{c}0,788 * * * \\
(0,002)\end{array}$ & $\begin{array}{c}0,747 * * * \\
(0,002)\end{array}$ \\
\hline Taxa de distorção idade-série & $\begin{array}{c}0,440 * * * \\
(0,003)\end{array}$ & $\begin{array}{c}0,510 * * * \\
(0,003)\end{array}$ \\
\hline \multicolumn{3}{|l|}{ Características das escolas } \\
\hline Total de funcionários por escola & $\begin{array}{c}30,444 * * * \\
(0,386)\end{array}$ & $\begin{array}{c}10,032 * * * \\
(0,160)\end{array}$ \\
\hline Proporção de meninas matriculadas & $\begin{array}{c}0,479 \\
(0,001)\end{array}$ & $\begin{array}{c}0,477 \\
(0,001)\end{array}$ \\
\hline Relação de recursos por sala & $\begin{array}{c}0,264 \\
(0,003)\end{array}$ & $\begin{array}{c}0,450 \\
(0,213)\end{array}$ \\
\hline Proporção de escolas com bibliotecas & $\begin{array}{c}0,387 * * * \\
(0,006)\end{array}$ & $\begin{array}{c}0,144 * * * \\
(0,005)\end{array}$ \\
\hline Proporção de escolas com laboratórios & $\begin{array}{c}0,108^{* * * *} \\
(0,004)\end{array}$ & $\begin{array}{c}0,016^{* * * *} \\
(0,002)\end{array}$ \\
\hline Proporção de escolas com Merenda Escolar & $\begin{array}{c}0,944 \\
(0,003)\end{array}$ & $\begin{array}{c}0,947 \\
(0,003)\end{array}$ \\
\hline Proporção de escolas com Livro Didático & $\begin{array}{c}0,973 * * * \\
(0,002)\end{array}$ & $\begin{array}{c}0,958 * * * \\
(0,003)\end{array}$ \\
\hline Proporção de escolas com Dinheiro Direto na Escola & $\begin{array}{c}0,671 * * * \\
(0,006)\end{array}$ & $\begin{array}{c}0,727 * * * \\
(0,006)\end{array}$ \\
\hline Proporção de escolas com Transporte escolar & $\begin{array}{c}0,060 * * * \\
(0,003)\end{array}$ & $\begin{array}{c}0,043 * * * \\
(0,003)\end{array}$ \\
\hline Proporção de escolas com Programa de Tecnologia Educacional & $\begin{array}{c}0,020 * * * \\
(0,002)\end{array}$ & $\begin{array}{c}0,006 * * * \\
(0,001)\end{array}$ \\
\hline Número de alunos por turma & $\begin{array}{c}26,285^{* * * *} \\
(0,114)\end{array}$ & $\begin{array}{c}23,774 * * * \\
(0,110)\end{array}$ \\
\hline Número de turmas por escola & $\begin{array}{c}7,048^{* * * *} \\
(0,074)\end{array}$ & $\begin{array}{c}3,448 * * * \\
(0,059)\end{array}$ \\
\hline Proporção de docentes com ensino superior & $\begin{array}{c}0,194 * * * \\
(0,003)\end{array}$ & $\begin{array}{c}0,115 * * * \\
(0,003)\end{array}$ \\
\hline Proporção de escolas com acesso à energia elétrica & $\begin{array}{c}0,857 * * * \\
(0,004)\end{array}$ & $\begin{array}{c}0,684 * * * \\
(0,006)\end{array}$ \\
\hline Proporção de escolas com acesso à água encanada & $\begin{array}{c}0,946^{* * * *} \\
(0,003)\end{array}$ & $\begin{array}{c}0,868 * * * \\
(0,004)\end{array}$ \\
\hline Proporção de escolas com acesso ao saneamento básico & $\begin{array}{c}0,896 * * * \\
(0,004)\end{array}$ & $\begin{array}{c}0,783 * * * \\
(0,005)\end{array}$ \\
\hline Proporção de escolas em áreas urbanas & $\begin{array}{c}0,679 * * * \\
(0,005)\end{array}$ & $\begin{array}{c}0,358 * * * \\
(0,006)\end{array}$ \\
\hline Número de alunos por escola & $\begin{array}{c}241,055^{* * * *} \\
(2,476)\end{array}$ & $\begin{array}{c}127,515^{* * * *} \\
(1,952)\end{array}$ \\
\hline $\begin{array}{l}\text { Características dos } \\
\text { municípios e dos estados } \\
\text { Gasto por aluno estadual (Em R\$) }\end{array}$ & $\begin{array}{c}531,506 * * * \\
(2,536)\end{array}$ & $\begin{array}{c}456,377 * * * \\
(1,935)\end{array}$ \\
\hline PIB per capita (Em R\$) & $\begin{array}{c}4.031,671 * * * \\
(38,861)\end{array}$ & $\begin{array}{c}2.728,579 * * * \\
(34,581)\end{array}$ \\
\hline População (Em número de habitantes) & $\begin{array}{c}207.371,642 * * * \\
\quad(5.456,862)\end{array}$ & $\begin{array}{c}65.233,273 * * * \\
(3.116,054)\end{array}$ \\
\hline $\begin{array}{l}\text { Relação entre gasto com educação } \\
\text { e cultura e gasto total - Gov Estadual }\end{array}$ & $\begin{array}{c}0,152 * * * \\
(0,000)\end{array}$ & $\begin{array}{c}0,162 * * * \\
(0,001)\end{array}$ \\
\hline
\end{tabular}

$* * *$ significante a $1 \%, * *$ significante a $5 \%$ e $*$ significante a $10 \%$

Em principio, como já ressaltado, muitas das características não observáveis que podem dificultar a identificação do verdadeiro efeito da descentralização são constantes no tempo. Sob a hipótese apresentada na equação (15), o estimador de diferença em diferenças elimina o viés de 
seleção em variáveis não observáveis.

Formalmente, o modelo de diferença em diferenças pode ser especificado por meio do seguinte modelo de regressão linear:

$$
y_{i j t}=\lambda_{t}+\alpha d_{i t}+x_{i j t} \gamma+z_{j t} \delta+\eta_{i}+v_{i t}, t=1997,1998 \ldots \text { e } 2002
$$

Em que $y_{i j t}$ constitui os indicadores de rendimento ou de distorção idade-série da escola $i$, localizada no município $j$ no ano $t, \lambda_{t}$ é o efeito fixo de tempo comum a todas as escolas, $d_{i t}$ é uma dummy que apresenta valor 1 se a escola $i$ pertencer ao grupo de tratamento após a descentralização e 0 caso contrário, $x_{i j t}$ são variáveis de controle da escola $i$ no ano $t, z_{j t}$ são os controles para o município $j$ no ano $t, \eta_{i}$ é o efeito fixo do estabelecimento de ensino e $v_{i t}$ é o termo de erro idiossincrático.

O modelo proposto na equação (23) assume que a descentralização afeta os indicadores educacionais avaliados imediatamente e que esse efeito é constante. Entretanto, pode transcorrer algum tempo até que gestão municipal implante novas políticas ou, até mesmo, para que as tais políticas apresentem algum impacto. Se o impacto da descentralização for cumulativo, as variáveis dependentes analisadas devem ser correlacionadas com o tempo de exposição ao tratamento (GALIANI; GERTLER; SCHARGRODSKY, 2008).

Com intuito de capturar o efeito do tempo de exposição ao tratamento, propõe-se o seguinte modelo:

$$
y_{i j t}=\lambda_{t}+\sum_{s=1}^{5} \alpha_{s} d_{i t}+x_{i t} \gamma+z_{j t} \delta+\eta_{i}+v_{i t}, t=1997,1998 \ldots \text { e } 2002
$$

Em que $d_{i t}$ são dummies iguais a 1 se a escola está descentralizada há 1, 2, 3, 4 ou 5 anos. Avalia-se até o quinto ano de descentralização pelo fato de o primeiro ciclo do ensino do ensino fundamental ser composto por 4 séries. Consequentemente, pode-se esperar que após 5 anos de descentralização a maior parte das crianças que estavam matriculadas na $1^{a}$ série quando o estabelecimento foi descentralizado, já estejam matriculadas no segundo ciclo do ensino fundamental.

Contudo, a decisão dos prefeitos em descentralizar determinadas escolas estaduais pode não apenas estar correlacionada com o efeito fixo, $\eta_{i}$, como também com tendências específicas de 
cada escola. Nesse contexto, propõe-se o seguinte modelo:

$$
y_{i j t}=\lambda_{t}+\sum_{s=1}^{5} \alpha_{s} d_{i t}+x_{i t} \gamma+z_{j t} \delta+\eta_{i}+g_{i} t+v_{i t}, t=1997,1998 \ldots \text { e } 2002
$$

Este modelo ${ }^{52}$ permite que tanto o efeito fixo, $\eta_{i}$, quanto a tendência de cada escola, $g_{i}$, sejam correlacionados com $d_{i t}$. Dessa maneira, é possível estimar consistentemente o impacto da descentralização ainda que o critério adotado pelos municípios para descentralizar determinadas escolas estaduais esteja correlacionado com tendências específicas destes estabelecimentos. A aplicação de primeiras diferenças a equação (25) permite eliminar o efeito fixo $\eta_{i}$, de modo que o novo efeito fixo seja dado por $g_{i}$ :

$$
\Delta y_{i j t}=\theta_{t}+\sum_{s=1}^{5} \alpha_{s} \Delta d_{i t}+\Delta x_{i t} \gamma+\Delta z_{j t} \delta+g_{i}+\Delta v_{i t}, t=1997,1998 \ldots . \text { e } 2002
$$

Em que $\theta_{t}=\lambda_{t}-\lambda_{t-1}$ é um novo conjunto de efeitos fixos de tempo.

Portanto, se o grupo de comparação escolhido constituir de fato um bom contrafactual para as escolas descentralizadas, e os prefeitos não tenham baseado a descentralização de algumas escolas estaduais em fatores não observáveis variantes no tempo, supostamente correlacionados com as variáveis dependentes avaliadas, um dos modelos econométricos propostos deve fornecer estimadores consistentes para a avaliação do impacto da descentralização (MADEIRA, 2007).

Como pode ser visto na Tabela 9, existem evidências de que os estados descentralizaram as piores escolas. É possível perceber que os grupos de tratamento e comparação são diferentes a ponto de que se a descentralização tivesse ocorrido nas escolas do grupo de comparação, teria apresentado um impacto diferente, ou seja, existem indicativos de que o efeito do tratamento é heterogêneo. Como já ressaltado, se a participação no programa estiver relacionada à expectativa de resultados que serão auferidos, o efeito estimado é o $\mathrm{ATT}^{53}$.

Semelhantemente ao modelo proposto na equação (20), as equações (24) e (26) podem ser estimadas por efeitos fixos e por primeiras diferenças. Espera-se que os controles adicionados, especificados na Descrição de Dados deste trabalho, sejam suficientes para resolver o viés de seleção em variáveis observáveis. Da mesma maneira, espera-se que a abordagem de diferença em diferenças controle o viés de seleção em não observáveis.

\footnotetext{
${ }^{52}$ No mínimo, são necessários 3 períodos de tempo para empregá-lo.

${ }^{53}$ Essa conclusão está baseada na hipótese de que o viés de seleção em variáveis não observáveis foi resolvido.
} 
A escolha entre as equações apresentadas está baseada primeiramente na consistência dos estimadores e, segundo lugar, na sua eficiência. Se as estimativas obtidas por meio da estimação da equação (24) por efeitos fixos e por primeiras diferenças forem próximas, existem evidências de que os estimadores obtidos são consistentes. A escolha entre os métodos depende da estrutura de correlação dos erros, $v_{i t}$ e $\Delta v_{i t}{ }^{54}$, respectivamente.

Por outro lado, se as estimativas forem muito díspares, por exemplo, com a indicação de efeitos opostos, existem indicativos de que a inclusão de apenas de apenas efeito fixo, $\eta_{i}$, na equação (24) não foi suficiente para controlar o viés de seleção em variáveis não observáveis. Dessa forma, a inclusão da variável $g_{i t}$ na equação (26) permite que a descentralização seja correlacionada com as tendências específicas de cada escola. Nesse caso, se as estimativas de efeitos fixos e primeiras diferenças forem próximas, a escolha entre os dois modelos depende da estrutura de correlação dos erros.

Os modelos expostos permitem avaliar os impactos de um, dois e até cinco anos de descentralização comparativamente à escola ter permanecido sob gestão estadual. São incluídas um série de variáveis que, até então, não haviam sido utilizadas na literatura empírica. Por exemplo, a maior rigidez de gasto imposta pelo FUNDEF afeta as escolas dos grupos de tratamento e comparação. A redistribuição de recursos dos estados para os municípios, e entre os municípios ricos e pobres, é ponderada por meio da evolução do gasto por aluno e dummies iguais para os governos estaduais e municipais que ganharam ou perderam recursos após a implantação do Fundo.

Por meio da disponibilidade de dados em painel e diversos controles para as escolas e os municípios nos quais elas estão localizadas, emprega-se o estimador de diferença em diferenças para tratamentos não aleatórios proposto por Heckman e Hotz (1989) para avaliar os impactos da descentralização de algumas escolas estaduais em uma amostra de municípios brasileiros.

\footnotetext{
${ }^{54}$ Para efeitos fixos, deve-se regredir os resíduos da equação (24), $\hat{v}_{i t}$, contra suas defasagens, $\hat{v}_{i t-1}$, de $t=1999$ a $t=2002$. Se houver evidências de que os resíduos são negativamente correlacionados, a estimação por efeitos fixos é mais eficiente. Já para a estimação por primeiras diferenças, deve-se regredir os resíduos da equação (26), $\hat{\Delta} v_{i t}$, contra suas defasagens, $\hat{\Delta} v_{i t-1}$, de $t=1999$ a $t=2002$. Se houver indicativos de que esses resíduos são não correlacionados, a estimação por primeiras diferenças é mais eficiente.
} 


\section{RESULTADOS PARA O PAINEL DE MUNICÍPIOS}

\subsection{Impactos da municipalização}

A Tabela 10 apresenta os resultados da estimação da equação (20) por efeitos fixos ${ }^{55}$. O objetivo é verificar o impacto da municipalização, entendida como o aumento da proporção de alunos de $1^{a}$ a $4^{a}$ série matriculados em escolas municipais, nas taxas de aprovação, de reprovação e de abandono. Semelhantemente aos trabalhos já realizados, também se procura avaliar o efeito da expansão da rede municipal, refletida no aumento da proporção de escolas municipais de $1^{a}$ a $4^{a}$ série no total de escolas.

O processo de descentralização gerencial do ensino fundamental ocorreu concomitantemente à perda de autonomia de gasto imposta aos estados e aos municípios, decorrente das regras de alocação dos recursos do FUNDEF. Dessa forma, considera-se, tanto para os municípios quanto para os estados em que eles estão localizados, um indicador de dependência fiscal obtido por meio da relação entre recursos advindos do FUNDEF e as despesas realizadas com educação e cultura.

Com o intuito de captar a redistribuição de recursos entre determinado estado e seus respectivos municípios e entre municípios ricos e pobres de um mesmo estado, consideram-se os gastos por aluno incorridos no âmbito dos governos estaduais e municipais. Ademais, como os incentivos para a municipalização estão relacionados à contribuição líquida feita para o FUNDEF, incluem-se duas variáveis dummies para indicar se os municípios e os estados em que eles estão localizados são "beneficiários" ou "doadores" de recursos para o Fundo.

Por fim, também são consideradas uma série de características dos estabelecimentos de ensino. Nesse sentido, por exemplo, ainda que o aumento do número de turmas por escola estivesse associado à municipalização observada no final da década de 90, não se deve afirmar que esse processo foi um desdobramento da gestão municipal. Consequentemente, a inclusão de características dos estabelecimentos de ensino visa estimar especificamente o efeito da expansão da

\footnotetext{
${ }^{55}$ Para os indicadores de rendimento, os estimadores de efeitos fixos e de primeiras diferenças fornecem estimativas semelhantes para o impacto da municipalização, o que sugere consistência dos estimadores. Tal constatação não foi verificada na estimação do impacto da municipalização na distorção idade-série, de modo que se optou não incluir seus resultados na tabela apresentada. O teste de correlação dos resíduos, $\hat{\Delta} v_{i t}$, sugere autocorrelação negativa, o que indica que a estimação por efeitos fixos tende a ser mais eficiente. Os resultados da estimação por primeiras diferenças e por efeitos fixos estão apresentados no Apêndice A.2 deste trabalho. Os erros-padrão são robustos e foram computados com base no cluster aplicado no nível dos municípios.
} 
gestão municipal ${ }^{56}$. Ainda nesse sentido, a inclusão das variáveis número de alunos por escola municipal e número de alunos por escola estadual tem o objetivo de isolar o efeito da municipalização dos impactos da expansão do acesso ao ensino fundamental ocorrida no final da década de $90^{57}$.

Tabela 10: Impactos da municipalização nos indicadores de rendimento $\left(1^{a}\right.$ a $4^{a}$ série $)$

\begin{tabular}{lccc}
\hline & Tx. de abandono & Tx. de aprovação & Tx. de reprovação \\
\hline Proporção de matrícula municipal & $0,033^{* * *}$ & $-0,082^{* * *}$ & $0,047^{* * * *}$ \\
Proporção de escolas municipais & $(0,007)$ & $(0,011)$ & $(0,008)$ \\
& $-0,016^{* * *}$ & $-0,008$ & $0,026^{* * *}$ \\
Dependência fiscal dos municípios & $(0,005)$ & $(0,010)$ & $(0,008)$ \\
& 0,006 & $0,013^{* *}$ & $-0,015^{* * * *}$ \\
Dependência fiscal dos estados & $(0,004)$ & $(0,006)$ & $(0,004)$ \\
& $0,038^{* * *}$ & $-0,033^{* * *}$ & $-0,008$ \\
Gasto por aluno dos municípios & $(0,006)$ & $(0,010)$ & $(0,007)$ \\
Gasto por aluno dos estados & $-0,000^{* *}$ & $0,000^{* *}$ & 0,000 \\
& $(0,000)$ & $(0,000)$ & $(0,000)$ \\
Município beneficiário de recursos do FUNDEF & $-0,000^{* * *}$ & $0,000^{* * *}$ & $-0,000$ \\
& $(0,000)$ & $(0,000)$ & $(0,000)$ \\
Estado beneficiário de recursos do FUNDEF & $-0,001$ & $-0,001$ & 0,001 \\
& $(0,001)$ & $(0,002)$ & $(0,001)$ \\
Controles & $-0,001$ & $0,006^{* * *}$ & $-0,002^{*}$ \\
Dummies de ano & $(0,002)$ & $(0,002)$ & $(0,001)$ \\
& Sim & Sim & Sim \\
R quadrado ajustado & Sim & Sim & Sim \\
Número de observações & & & \\
\hline
\end{tabular}

a Os estados e municípios foram classificados como beneficiários de recursos do FUNDEF se a ganho líquido (total de recursos advindos do Fundo subtraído do montante total contribuído) for positivo.

$* * *$ significante a $1 \%, * *$ significante a $5 \%$ e $*$ significante a $10 \%$

Os resultados encontrados fornecem evidências de que a municipalização, tal como ocorreu na maior parte dos municípios brasileiros, acarretou piora dos indicadores educacionais avaliados. Estima-se que o aumento de $10 \%$ da proporção de alunos matriculados em estabelecimentos municipais implique elevação de $0,33 \%$ na taxa de abandono, de $0,47 \%$ na taxa de reprovação e diminuição de $0,82 \%$ na taxa de aprovação.

Os resultados sugerem que a maior parte dos municípios não estava preparada para absorver maior proporção de alunos do ensino fundamental ${ }^{58}$. No entanto, importante ressaltar que a municipalização ocorreu em um contexto de expansão do acesso à educação fundamental. Dessa forma, a queda dos indicadores educacionais avaliados pode estar relacionada à expansão do ensino aos alunos que tinham menor probabilidade de frequentar a escola. Se por estarem fora da escola, tais alunos apresentavam rendimento inferior, e se os controles adicionados à regres-

\footnotetext{
${ }^{56}$ Todas as variáveis utilizadas como controles estão apresentadas na Tabela 17 do Apêndice A.1 deste trabalho.

${ }^{57}$ De 1997 a 2002, foi calculado, para cada município da amostra, a evolução do número médio de alunos nas escolas estaduais e municipais. As regressões sem a inclusão dessas variáveis como controles estão apresentadas no Apêndice A.2 deste trabalho.

${ }^{58}$ Também existe a hipótese de que os alunos da rede estadual apresentavam rendimento inferior.
} 
são não forem suficientes para isolar os impactos da gestão municipal, a piora dos indicadores educacionais também decorreu da universalização do ensino fundamental.

Contrariando a literatura teórica que prevê efeitos benéficos para a descentralização da educação, principalmente por pressupor a adequação dos serviços às preferências de grupos mais homogêneos, pode-se argumentar que embora as Secretarias Municipais de Educação estejam mais próximas da população e consigam verificar com mais facilidade suas necessidades, esses órgãos apresentam menor capacitação técnica que as Secretarias Estaduais (BANCO MUNDIAL, 2002). Em segundo lugar, a municipalização não foi um processo organizado e planejado de transferência de alunos entre as redes. Existem evidências de que os municípios a implantaram sobretudo para não perder recursos, sem que tenha havido maior preocupação com a qualidade da educação oferecida ${ }^{59}$.

Até a intensificação do processo de municipalização, ainda que os governos estaduais pudessem não atender determinadas necessidades específicas de seus municípios, eles apresentavam maior experiência com a gestão do ensino fundamental. Como pode ser visto na Tabela 4, os municípios que mais se municipalizaram entre 1997 e 2002 eram menos experientes na gestão do ensino fundamental de $1^{a}$ a $4^{a}$ série $^{60}$. Nesse sentido, os resultados negativos encontrados indicam que muitos deles não tiveram condições de formar uma equipe de profissionais qualificados para desempenhar as atividades necessárias à gestão efetiva do sistema escolar.

No que concerne à expansão da rede municipal, os resultados são ambíguos. Estima-se que o aumento de $10 \%$ da proporção de escolas de $1^{a}$ a $4^{a}$ implique redução de $0,16 \%$ na taxa de abandono e aumento de $0,28 \%$ na taxa de reprovação. Esses números indicam que expansão das escolas municipais, embora tenha contribuído para que as crianças permanecessem na escola, não criou incentivos que estimulassem o aprendizado ${ }^{61}$. Nesse ponto, ressalta-se o fato de que ao se expandir a rede, há o aumento da probabilidade de receber crianças suscetíveis a menores indicadores de rendimento.

Os resultados encontrados para menor autonomia de gasto imposta aos municípios sugerem que

\footnotetext{
${ }^{59}$ Conforme apresentado na Descrição dos Dados, os municípios que mais procuraram expandir a proporção de alunos de $1^{a}$ a $4^{a}$ série em escolas municipais eram, em grande parte, doadores de recursos para o FUNDEF.

${ }^{60}$ Estes municípios detinham apenas 40,2\% das matrículas em 1997.

${ }^{61}$ Esse argumento é válido especialmente em municípios mais pobres e, consequentemente, com população menos instruída. Ainda que a escola chegue à comunidade, a criança pode não ter quem ajudá-la a fazer o dever de casa, por exemplo.
} 
as externalidades positivas associadas às regras de alocação dos recursos do FUNDEF contrabalancearam a maior rigidez quanto à alocação dos recursos. Estima-se que o aumento de $10 \%$ da relação entre recursos oriundos do FUNDEF e despesas com educação e cultura impliquem aumento de $0,13 \%$ da taxa de aprovação e redução de $0,15 \%$ da taxa de reprovação. Por outro lado, a maior rigidez de gasto imposta aos governos estaduais indica aumento na taxa de abandono e queda na taxa de reprovação. Nesse sentido, no âmbito dos governos estaduais, as regras de alocação dos recursos parecem ter sido contrárias às necessidades de alocação dos recursos desses entes federativos ${ }^{62}$.

Os resultados apresentados são condizentes com a literatura teórica que prevê efeitos perversos para a descentralização ocorrida em níveis de governo com menor habilidade técnica e capacitação institucional que a gestão central. Seria razoável esperar efeitos positivos se os municípios já tivessem maior experiência com a gestão do ensino fundamental e se o processo de municipalização fosse caracterizado por uma transferência organizada de alunos entre as redes de ensino $^{63}$.

\subsection{Diferenças entre os municípios que mais e menos se municipalizaram}

Conforme ressaltado na Descrição dos Dados, dentre outras separações, é possível classificar os municípios brasileiros entre os que mais e menos se municipalizaram. A mediana de aumento da proporção de matrículas municipais de $1^{a}$ e $4^{a}$ série é $21,3 \%$. De tal modo, classificaram-se os municípios em 2 grupos. O Grupo 1 é constituído por municípios que aumentaram a proporção de matriculas municipais em até $21,3 \%$. O Grupo 2 é constituído por municípios que elevaram a proporção de matrículas municipais acima dessa faixa. A Tabela 11 apresenta os resultados da interação entre a proporção de matrículas e a proporção de escolas municipais de $1^{a}$ a $4^{a}$ série com os dois grupos de municípios estabelecidos.

\footnotetext{
${ }^{62}$ É possível argumentar que a imposição de alocar 60\% dos recursos do FUNDEF com pagamento de professores em exercício seja contrária às preferências estaduais justamente porque os estados já apresentavam salários mais elevados do que os municípios.

${ }^{63}$ Como apresentado anteriormente, o processo de municipalização do primeiro ciclo do ensino fundamental ocorreu por meio do tamanho médio do número de alunos por escola, o que indica que os municípios absorveram alunos da forma como podiam, sem que tenha havido maior preocupação com a capacidade do sistema municipal de recebê-los.
} 
Tabela 11: Diferenças dos impactos da municipalização entre os municípios que mais e os que menos se municipalizaram $\left(1^{a}\right.$ a $4^{a}$ série $)$

\begin{tabular}{|c|c|c|c|c|}
\hline & & Tx. de abandono & Tx. de aprovação & Tx. de reprovação \\
\hline \multirow{4}{*}{ Grupo 1} & Proporção de matrícula municipal & 0,011 & $-0,042 * *$ & 0,021 \\
\hline & & $(0,014)$ & $(0,021)$ & $(0,014)$ \\
\hline & Proporção de escolas municipais & $0,031 * * *$ & $-0,084 * * *$ & $0,051 * * *$ \\
\hline & & $(0,007)$ & $(0,011)$ & $(0,008)$ \\
\hline \multirow{4}{*}{ Grupo 2} & Proporção de matrícula municipal & $-0,034 * * *$ & 0,006 & $0,032 * * *$ \\
\hline & & $(0,009)$ & $(0,019)$ & $(0,011)$ \\
\hline & \multirow[t]{2}{*}{ Proporção de escolas municipais } & $-0,014 * *$ & $-0,010$ & $0,026 * * *$ \\
\hline & & $(0,006)$ & $(0,011)$ & $(0,008)$ \\
\hline & \multirow[t]{2}{*}{ Dependência fiscal dos municípios } & 0,005 & $0,012 *$ & $-0,013 * * *$ \\
\hline & & $(0,004)$ & $(0,006)$ & $(0,004)$ \\
\hline & \multirow[t]{2}{*}{ Dependência fiscal dos estados } & $0,038 * * *$ & $-0,031 * * *$ & $-0,010$ \\
\hline & & $(0,006)$ & $(0,010)$ & $(0,007)$ \\
\hline & \multirow[t]{2}{*}{ Gasto por aluno dos municípios } & $-0,000 * *$ & $0,000 * *$ & 0,000 \\
\hline & & $(0,000)$ & $(0,000)$ & $(0,000)$ \\
\hline & \multirow[t]{2}{*}{ Gasto por aluno dos estados } & $-0,000 * * *$ & $0,000 * * *$ & $-0,000$ \\
\hline & & $(0,000)$ & $(0,000)$ & $(0,000)$ \\
\hline & \multirow[t]{2}{*}{ Município beneficiário de recursos do FUNDEF } & $-0,001$ & $-0,001$ & 0,001 \\
\hline & & $(0,001)$ & $(0,002)$ & $(0,001)$ \\
\hline & \multirow[t]{2}{*}{ Estado beneficiário de recursos do FUNDEF } & $-0,001$ & $0,006 * * *$ & $-0,002$ \\
\hline & & $(0,002)$ & $(0,002)$ & $(0,001)$ \\
\hline & Controles & Sim & Sim & Sim \\
\hline & Dummies de ano & Sim & Sim & Sim \\
\hline & R quadrado ajustado & 0,160 & 0,097 & 0,057 \\
\hline & Número de observações & 21.461 & 21.461 & 21.461 \\
\hline
\end{tabular}

${ }^{a}$ O Grupo 1 é constituído por municípios que aumentaram a proporção de matrículas municipais em até 21,3\% (mediana do aumento da proporção de matrículas de $1^{a}$ e $4^{a}$ série em escolas municipais) entre 1997 e 2002.

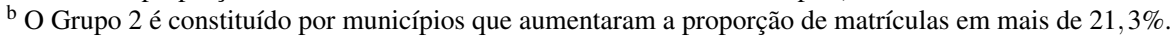

$* * *$ significante a $1 \%, * *$ significante a $5 \%$ e $*$ significante a $10 \%$

Os resultados apresentados fornecem evidências de aumento de reprovação nos municípios que aumentaram mais de $21,3 \%$ a proporção de matrículas municipais de $1^{a}$ e $4^{a}$ série $^{64}$. Para os municípios do primeiro grupo, os resultados indicam que a municipalização implicou queda da taxa de aprovação e não apresentou impactos estatisticamente significantes nos demais indicadores de rendimento avaliados ${ }^{65}$.

Esses resultados corroboram a hipótese de que os municípios não estavam preparados para absorver maior proporção de alunos do ensino fundamental. Os municípios do Grupo 1, ainda que já detivessem $72,9 \%$ das matrículas de $1^{a}$ a $4^{a}$ série em 1997 , não conseguiram absorver um maior número de alunos simultaneamente ao aumento da qualidade da educação oferecida. Os municípios do Grupo 2 detinham apenas 40,2\% da matrícula, o que evidencia a falta de

\footnotetext{
${ }^{64}$ Para este grupo de municípios, existem evidências de queda na taxa de abandono.

${ }^{65}$ Para cada uma das regressões apresentadas na Tabela 11, realizou-se um teste de hipótese em que a hipótese nula consiste em $\beta_{1}=\beta_{2}$. Em que $\beta_{1}$ é o impacto da municipalização para os municípios do Grupo 1 e $\beta_{2}$ é o impacto da municipalização para os municípios do Grupo 2. A 5\% de significância, a hipótese nula é rejeitada para as regressões que explicam a taxa de abandono e a taxa de aprovação, o que sugere que de fato há diferenças nos impactos da municipalização entre os municípios que mais e os menos de municipalizaram.
} 
experiência com a gestão do ensino fundamental.

Semelhantemente aos resultados ${ }^{66}$ apresentados na Tabela 10, a expansão da rede municipal, representada pelo aumento da proporção de escolas municipais de $1^{a}$ a $4^{a}$ série no total de escolas, apresentou efeitos ambíguos para os municípios do Grupo 2. Nesse grupo, ainda que a expansão da rede municipal pareça ter contribuído para que as crianças permanecessem na escola, os resultados sugerem que não foram implantadas políticas que estimulassem o aprendizado. Para os municípios do Grupo 1, a expansão da rede municipal apresentou efeitos negativos em todos os indicadores avaliados.

De um lado, os efeitos negativos para expansão da rede municipal nos Grupos 1 e 2 podem decorrer do fato de que ao expandir a rede, tais municípios receberam os alunos que apresentavam menor probabilidade de estar na escola. De outro, a expansão da rede fundamental municipal pode ter sido acompanhada pela absorção dos piores alunos que, até então, estavam matriculados em escolas estaduais.

No âmbito dos municípios, no que concerne à maior rigidez de gasto imposta pelo FUNDEF, os resultados apresentados, coerentemente com a análise anterior, sugerem que as externalidades positivas associadas aos recursos do Fundo parecem ter contrabalanceado a perda de autonomia de gasto. Destacam-se, por exemplo, a exclusividade dos recursos do Fundo no pagamento de professores em efetivo exercício e o estabelecimento de Conselhos para fiscalização do uso das verbas. Já no âmbito dos estados, as amarras impostas quanto ao direcionamento dos recursos indicam maiores taxas de abandono e menores taxas de aprovação.

\footnotetext{
${ }^{66}$ Para cada uma das regressões apresentadas na Tabela 11, realizou-se um teste de hipótese em que a hipótese nula consiste em $\beta_{1}=\beta_{2}$. Em que $\beta_{1}$ é o impacto da expansão da rede municipal para os municípios do Grupo 1 e $\beta_{2}$ é o impacto da expansão da rede municipal para os municípios do Grupo 2. A $5 \%$ de significância, a hipótese nula é rejeitada para as regressões que buscam explicar as taxas de abandono e de distorção idade-série. No que concerne à taxa de aprovação não foi encontrada diferença estatisticamente significante entre $\beta_{1}$ e $\beta_{2}$.
} 


\section{RESULTADOS PARA O PAINEL DE ESCOLAS}

\subsection{Impactos da descentralização das escolas estaduais}

Com intuito de avaliar um componente específico de todo o processo de municipalização, a descentralização de algumas escolas estaduais, estima-se o modelo proposto na equação (26) por efeitos fixos ${ }^{67}$. Como a metodologia de diferença em diferenças compara os indicadores educacionais das escolas dos grupos de tratamento e comparação, o modelo apresentado também considera uma série de diferenças, entre as escolas dos dois grupos (Tabela 9), que possivelmente estejam correlacionadas com a descentralização e com as variáveis dependentes analisadas.

Os resultados apresentados nas colunas de número 1 da Tabela 12 sugerem que, nos primeiros dois anos, a descentralização das escolas estaduais apresentou impactos negativos nos indicadores de rendimento avaliados ${ }^{68}$. Comparativamente às escolas que permaneceram sob gestão estadual, estima-se que as escolas descentralizadas, após um ano de descentralização, tenham apresentado taxas de abandono e de distorção idade-série 0,048\% e 0,038\% superiores, respectivamente, e taxa de aprovação 0,043\% inferior. Após 2 anos de descentralização, os resultados apresentados sugerem que os efeitos negativos persistem nas taxas de abandono e de aprovação.

\footnotetext{
${ }^{67} \mathrm{O}$ modelo proposto na equação (25) foi estimado por efeitos fixos e por primeiras diferenças. Contudo, as estimativas dos impactos da descentralização destoaram muito, o que sugere que a inclusão de apenas efeito fixo para as escolas não foi suficiente para controlar o viés de seleção em variáveis não observáveis. De tal modo, estimou-se o modelo de tendência aleatória apresentado na equação (26) por efeitos fixos a primeiras diferenças. Os resultados encontrados para os efeitos da descentralização são semelhantes, o que indica que a maior parte das diferenças entre os grupos de tratamento e comparação foram controladas. O teste de correlação dos resíduos, $\hat{\Delta} v_{i t}$, sugere autocorrelação negativa, o que indica que a estimação por efeitos fixos tende a ser mais eficiente. Dessa maneira, optou-se por apresentar os resultados da estimação por efeitos fixos. Os demais resultados estão no Apêndice A.2 deste trabalho.

${ }^{68}$ Os erros padrão são robustos e foram computados com base no cluster aplicado no nível das escolas.
} 
Tabela 12: Impactos da descentralização das escolas estaduais nos indicadores de rendimento e de distorção idade-série ( $1^{a}$ a $4^{a}$ série)

\begin{tabular}{|c|c|c|c|c|c|c|c|c|c|c|c|c|}
\hline & \multicolumn{3}{|c|}{ Tx. de abandono } & \multicolumn{3}{|c|}{ Tx. de aprovação } & \multicolumn{3}{|c|}{ Tx. de reprovação } & \multicolumn{3}{|c|}{$\begin{array}{l}\text { Tx. de distorção } \\
\text { idade-série }\end{array}$} \\
\hline & 1 & 2 & 3 & 1 & 2 & 3 & 1 & 2 & 3 & 1 & 2 & 3 \\
\hline 1 ano de descentralização & $\begin{array}{c}0,048 * * * \\
(0,014)\end{array}$ & $\begin{array}{c}0,046 * * * \\
(0,015)\end{array}$ & $\begin{array}{c}0,079 * * \\
(0,039)\end{array}$ & $\begin{array}{c}-0,043^{* * *} \\
(0,017)\end{array}$ & $\begin{array}{c}-0,041^{* *} \\
(0,018)\end{array}$ & $\begin{array}{l}-0,073 \\
(0,051)\end{array}$ & $\begin{array}{l}-0,005 \\
(0,013)\end{array}$ & $\begin{array}{l}-0,005 \\
(0,013)\end{array}$ & $\begin{array}{l}-0,006 \\
(0,036)\end{array}$ & $\begin{array}{l}0,038^{* *} \\
(0,016)\end{array}$ & $\begin{array}{l}0,036^{* *} \\
(0,017)\end{array}$ & $\begin{array}{l}-0,072 \\
(0,073)\end{array}$ \\
\hline 2 anos de descentralização & $\begin{array}{c}0,036^{* * *} \\
(0,018)\end{array}$ & $\begin{array}{c}0,029 \\
(0,020)\end{array}$ & $\begin{array}{c}0,056 \\
(0,038)\end{array}$ & $\begin{array}{l}-0,038^{*} \\
(0,022)\end{array}$ & $\begin{array}{l}-0,031 \\
(0,024)\end{array}$ & $\begin{array}{l}-0,051 \\
(0,048)\end{array}$ & $\begin{array}{c}0,002 \\
(0,015)\end{array}$ & $\begin{array}{c}0,001 \\
(0,016)\end{array}$ & $\begin{array}{l}-0,006 \\
(0,033)\end{array}$ & $\begin{array}{c}0,030 \\
(0,020)\end{array}$ & $\begin{array}{c}0,026 \\
(0,024)\end{array}$ & $\begin{array}{l}-0,061 \\
(0,072)\end{array}$ \\
\hline 3 anos de descentralização & $\begin{array}{c}0,028 \\
(0,022)\end{array}$ & $\begin{array}{c}0,014 \\
(0,027)\end{array}$ & $\begin{array}{c}0,033 \\
(0,038)\end{array}$ & $\begin{array}{l}-0,007 \\
(0,027)\end{array}$ & $\begin{array}{c}0,010 \\
(0,033)\end{array}$ & $\begin{array}{c}0,005 \\
(0,048)\end{array}$ & $\begin{array}{l}-0,022 \\
(0,018)\end{array}$ & $\begin{array}{l}-0,023 \\
(0,021)\end{array}$ & $\begin{array}{l}-0,038 \\
(0,031)\end{array}$ & $\begin{array}{c}0,019 \\
(0,025)\end{array}$ & $\begin{array}{c}0,011 \\
(0,033)\end{array}$ & $\begin{array}{l}-0,048 \\
(0,073)\end{array}$ \\
\hline 4 anos de descentralização & $\begin{array}{c}0,017 \\
(0,027)\end{array}$ & $\begin{array}{l}-0,005 \\
(0,035)\end{array}$ & $\begin{array}{c}0,009 \\
(0,043)\end{array}$ & $\begin{array}{c}0,025 \\
(0,033)\end{array}$ & $\begin{array}{c}0,050 \\
(0,043)\end{array}$ & $\begin{array}{c}0,062 \\
(0,054)\end{array}$ & $\begin{array}{l}-0,042^{*} \\
(0,022)\end{array}$ & $\begin{array}{l}-0,045^{*} \\
(0,027)\end{array}$ & $\begin{array}{c}-0,071^{* *} \\
(0,033)\end{array}$ & $\begin{array}{l}-0,001 \\
(0,031)\end{array}$ & $\begin{array}{l}-0,012 \\
(0,043)\end{array}$ & $\begin{array}{l}-0,045 \\
(0,079)\end{array}$ \\
\hline 5 anos de descentralização & $\begin{array}{c}0,011 \\
(0,032)\end{array}$ & $\begin{array}{l}-0,018 \\
(0,045)\end{array}$ & $\begin{array}{l}-0,021 \\
(0,052)\end{array}$ & $\begin{array}{c}0,057 \\
(0,040)\end{array}$ & $\begin{array}{l}0,090^{*} \\
(0,054)\end{array}$ & $\begin{array}{c}0,142 * * \\
(0,067)\end{array}$ & $\begin{array}{c}-0,068^{* * * *} \\
(0,026)\end{array}$ & $\begin{array}{c}-0,072^{* *} \\
(0,034)\end{array}$ & $\begin{array}{c}-0,121 \text { **** } \\
(0,041)\end{array}$ & $\begin{array}{l}-0,029 \\
(0,037)\end{array}$ & $\begin{array}{l}-0,043 \\
(0,054)\end{array}$ & $\begin{array}{l}-0,037 \\
(0,091)\end{array}$ \\
\hline Dependência fiscal dos municípios & $\begin{array}{l}-0,019 \\
(0,012)\end{array}$ & $\begin{array}{l}-0,021^{*} \\
(0,012)\end{array}$ & $\begin{array}{l}-0,014 \\
(0,014)\end{array}$ & $\begin{array}{c}0,044 * * * \\
(0,016)\end{array}$ & $\begin{array}{c}0,047 * * * \\
(0,016)\end{array}$ & $\begin{array}{c}0,008 \\
(0,018)\end{array}$ & $\begin{array}{c}-0,025^{* *} \\
(0,013)\end{array}$ & $\begin{array}{l}-0,025^{*} \\
(0,013)\end{array}$ & $\begin{array}{c}0,006 \\
(0,014)\end{array}$ & $\begin{array}{c}-0,037 * * * \\
(0,014)\end{array}$ & $\begin{array}{c}-0,038 * * * \\
(0,014)\end{array}$ & $\begin{array}{l}-0,001 \\
(0,016)\end{array}$ \\
\hline Dependência fiscal dos estados & $\begin{array}{c}0,046 \text { *** } \\
(0,016)\end{array}$ & $\begin{array}{c}0,050 * * * \\
(0,016)\end{array}$ & $\begin{array}{l}- \\
-\end{array}$ & $\begin{array}{l}-0,033 \\
(0,020)\end{array}$ & $\begin{array}{l}-0,037^{*} \\
(0,020)\end{array}$ & - & $\begin{array}{l}-0,013 \\
(0,015)\end{array}$ & $\begin{array}{c}-0,012 \\
(0,015)\end{array}$ & - & $\begin{array}{c}0,049 * * * \\
(0,018)\end{array}$ & $\begin{array}{c}0,050 * * * \\
(0,018)\end{array}$ & $\begin{array}{l}- \\
-\end{array}$ \\
\hline Gasto por aluno dos municípios & $\begin{array}{l}-0,000 \\
(0,000)\end{array}$ & $\begin{array}{l}-0,000 \\
(0,000)\end{array}$ & $\begin{array}{l}-0,000 \\
(0,000)\end{array}$ & $\begin{array}{l}-0,000 \\
(0,000)\end{array}$ & $\begin{array}{l}-0,000 \\
(0,000)\end{array}$ & $\begin{array}{c}0,000 \\
(0,000)\end{array}$ & $\begin{array}{l}0,000^{*} \\
(0,000)\end{array}$ & $\begin{array}{l}0,000 * \\
(0,000)\end{array}$ & $\begin{array}{c}0,000 \\
(0,000)\end{array}$ & $\begin{array}{c}-0,000 * * \\
(0,000)\end{array}$ & $\begin{array}{c}-0,000^{* *} \\
(0,000)\end{array}$ & $\begin{array}{c}-0,000 * * \\
(0,000)\end{array}$ \\
\hline Gasto por aluno dos estados & $\begin{array}{c}0,000^{* * * *} \\
(0,000)\end{array}$ & $\begin{array}{c}0,000 * * * \\
(0,000)\end{array}$ & $\begin{array}{l}-0,000 \\
(0,001)\end{array}$ & $\begin{array}{c}-0,000 * * * \\
(0,000)\end{array}$ & $\begin{array}{c}-0,000^{* * * *} \\
(0,000)\end{array}$ & $\begin{array}{c}0,001 \\
(0,001)\end{array}$ & $\begin{array}{l}-0,000 \\
(0,000)\end{array}$ & $\begin{array}{l}-0,000 \\
(0,000)\end{array}$ & $\begin{array}{l}-0,001 \\
(0,001)\end{array}$ & $\begin{array}{c}0,000 \\
(0,000)\end{array}$ & $\begin{array}{c}0,000 \\
(0,000)\end{array}$ & $\begin{array}{l}-0,000^{*} \\
(0,000)\end{array}$ \\
\hline Município beneficiário de recursos do FUNDEF & $\begin{array}{c}-0,008^{* *} \\
(0,003)\end{array}$ & $\begin{array}{c}-0,008^{* *} \\
(0,003)\end{array}$ & $\begin{array}{c}-0,008^{* *} \\
(0,003)\end{array}$ & $\begin{array}{c}0,017 * * * \\
(0,005)\end{array}$ & $\begin{array}{c}0,017 * * * \\
(0,005)\end{array}$ & $\begin{array}{l}0,010^{* *} \\
(0,005)\end{array}$ & $\begin{array}{c}-0,009^{* *} \\
(0,004)\end{array}$ & $\begin{array}{c}-0,009 * * \\
(0,004)\end{array}$ & $\begin{array}{c}-0,002 \\
(0,004)\end{array}$ & $\begin{array}{c}-0,002 \\
(0,004)\end{array}$ & $\begin{array}{c}-0,002 \\
(0,004)\end{array}$ & $\begin{array}{l}-0,000 \\
(0,004)\end{array}$ \\
\hline Estado beneficiário de recursos do FUNDEF & $\begin{array}{c}-0,014 * * * \\
(0,003)\end{array}$ & $\begin{array}{c}-0,014 * * * \\
(0,003)\end{array}$ & $\begin{array}{c}0,127 \\
(0,304)\end{array}$ & $\begin{array}{c}0,016^{* * * *} \\
(0,003)\end{array}$ & $\begin{array}{c}0,016 \text { **** } \\
(0,003)\end{array}$ & $\begin{array}{l}-0,393 \\
(0,562)\end{array}$ & $\begin{array}{l}-0,002 \\
(0,002)\end{array}$ & $\begin{array}{c}-0,002 \\
(0,002)\end{array}$ & $\begin{array}{c}0,265 \\
(0,265)\end{array}$ & $\begin{array}{l}-0,005^{*} \\
(0,003)\end{array}$ & $\begin{array}{l}-0,005^{*} \\
(0,003)\end{array}$ & $\begin{array}{c}0,204 \\
(0,269)\end{array}$ \\
\hline Controles & Sim & Sim & Sim & Sim & Sim & Sim & Sim & Sim & Sim & Sim & Sim & Sim \\
\hline Dummies de ano & Sim & Sim & $\operatorname{Sim}$ & Sim & Sim & Sim & Sim & Sim & Sim & Sim & Sim & Sim \\
\hline $\mathrm{R}$ quadrado ajustado & 0,025 & 0,025 & 0,040 & 0,021 & 0,021 & 0,042 & 0,009 & 0,009 & 0,031 & 0,071 & 0,071 & 0,084 \\
\hline Observações & 42.808 & 42.808 & 42.808 & 42.808 & 42.808 & 42.808 & 42.808 & 42.808 & 42.808 & 37.806 & 37.806 & 37.806 \\
\hline
\end{tabular}

a As colunas de número 1 apresentam os resultados obtidos por meio da estimação da equação (26) por efeitos fixos.

b As colunas de número 2 apresentam os resultados obtidos por meio da estimação da equação (26) por efeitos fixos e a inclusão de uma tendência não linear para as escolas do grupo de comparação.

c As colunas de número 3 apresentam os resultados obtidos por meio da estimação da equação (26) por efeitos fixos e a inclusão de uma interação entre os estados e os anos estudados na amostra de escolas do grupo de comparação 
Semelhantemente à análise realizada por municípios, os impactos negativos da descentralização podem estar relacionados à expansão do ensino fundamental ocorrida no final da década de 90. É possível que a piora dos indicadores educacionais avaliados esteja associada à absorção de alunos que apresentavam menor probabilidade de estar na escola, por exemplo, o aumento da matrícula de crianças com idade superior a recomendada para a série. Com intuito de verificar se essa hipótese é válida, propõe-se a estimação do mesmo modelo apenas para crianças matriculadas na $1^{a}$ série $^{69}$, utilizando como controle a proporção de matriculados com idade superior a 7 anos, idade ideal para o ingresso no ensino fundamental ${ }^{70}$.

Se após controlar a distorção idade-série dos alunos ingressantes na $1^{a}$ serie, as estimativas para os efeitos da descentralização alterarem muito, existem evidências de que parte da piora dos indicadores educacionais está associada à matrícula dessas crianças, que possivelmente apresentavam rendimento inferior. A Tabela 13 apresenta nas colunas de números 1 e 2 os resultados da estimação da equação (26) sem e com distorção idade série como controle, respectivamente.

\footnotetext{
${ }^{69} \mathrm{O}$ exercício é feito apenas para a primeira série, porque, para as demais séries, a mudança nesse indicador pode estar relacionada à descentralização ocorrida no período. Por exemplo, a distorção idade-série pode ser elevada para os alunos matriculados na $3^{a}$ série por dois fatores principais: i) a descentralização implicou aumento da reprovação e, consequentemente da distorção idade-série; e ii) a expansão do acesso ao ensino fundamental estimulou algumas crianças a retomarem os estudos. Nesse caso, algumas delas regressaram à $3^{a}$ série com idade superior a ideal.

${ }^{70}$ Atualmente a idade ideal para ingresso no $1^{\circ}$ ano do ensino fundamental é de 6 anos.
} 
Tabela 13: Impactos da descentralização das escolas estaduais nos indicadores de rendimento e de distorção idade-série ( $1^{a}$ série)

\begin{tabular}{|c|c|c|c|c|c|c|}
\hline & \multicolumn{2}{|c|}{ Tx. de abandono } & \multicolumn{2}{|c|}{ Tx. de aprovação } & \multicolumn{2}{|c|}{ Tx. de reprovação } \\
\hline & 1 & 2 & 1 & 2 & 1 & 2 \\
\hline 1 ano de descentralização & $\begin{array}{c}0,091 * * * \\
(0,024)\end{array}$ & $\begin{array}{c}0,090 * * * \\
(0,024)\end{array}$ & $\begin{array}{c}-0,149 * * * \\
(0,031)\end{array}$ & $\begin{array}{c}-0,144 * * * \\
(0,031)\end{array}$ & $\begin{array}{c}0,058 * * * \\
(0,022)\end{array}$ & $\begin{array}{c}0,054 * * \\
(0,022)\end{array}$ \\
\hline 2 anos de descentralização & $\begin{array}{c}0,078^{* * *} * \\
(0,029)\end{array}$ & $\begin{array}{c}0,076^{* * * *} \\
(0,030)\end{array}$ & $\begin{array}{c}-0,156^{* * * *} \\
(0,038)\end{array}$ & $\begin{array}{c}-0,150 * * * \\
(0,038)\end{array}$ & $\begin{array}{c}0,078 * * * \\
(0,027)\end{array}$ & $\begin{array}{c}0,073 * * * \\
(0,027)\end{array}$ \\
\hline 3 anos de descentralização & $\begin{array}{l}0,058^{*} \\
(0,035)\end{array}$ & $\begin{array}{c}0,058 \\
(0,035)\end{array}$ & $\begin{array}{c}-0,127 * * * \\
(0,045)\end{array}$ & $\begin{array}{c}-0,121 * * * \\
(0,045)\end{array}$ & $\begin{array}{c}0,068 * * \\
(0,033)\end{array}$ & $\begin{array}{l}0,064^{*} \\
(0,033)\end{array}$ \\
\hline 4 anos de descentralização & $\begin{array}{c}0,047 \\
(0,043)\end{array}$ & $\begin{array}{c}0,048 \\
(0,043)\end{array}$ & $\begin{array}{c}-0,106^{*} \\
(0,054)\end{array}$ & $\begin{array}{l}-0,102^{*} \\
(0,054)\end{array}$ & $\begin{array}{c}0,059 \\
(0,040)\end{array}$ & $\begin{array}{c}0,054 \\
(0,040)\end{array}$ \\
\hline 5 anos de descentralização & $\begin{array}{c}0,036 \\
(0,051)\end{array}$ & $\begin{array}{c}0,037 \\
(0,051)\end{array}$ & $\begin{array}{c}-0,078 \\
(0,065)\end{array}$ & $\begin{array}{l}-0,074 \\
(0,065)\end{array}$ & $\begin{array}{c}0,042 \\
(0,048)\end{array}$ & $\begin{array}{c}0,038 \\
(0,048)\end{array}$ \\
\hline Dependência fiscal dos municípios & $\begin{array}{l}-0,042 \\
(0,026)\end{array}$ & $\begin{array}{l}-0,037 \\
(0,026)\end{array}$ & $\begin{array}{c}0,075^{* *} \\
(0,034)\end{array}$ & $\begin{array}{c}0,068 * * \\
(0,034)\end{array}$ & $\begin{array}{l}-0,033 \\
(0,026)\end{array}$ & $\begin{array}{l}-0,031 \\
(0,026)\end{array}$ \\
\hline Dependência fiscal dos estados & $\begin{array}{c}0,117 * * * \\
(0,026)\end{array}$ & $\begin{array}{c}0,115^{* * * *} \\
(0,026)\end{array}$ & $\begin{array}{c}-0,222 * * * \\
(0,031)\end{array}$ & $\begin{array}{c}-0,219 * * * \\
(0,031)\end{array}$ & $\begin{array}{c}0,105 * * * \\
(0,021)\end{array}$ & $\begin{array}{c}0,104 * * * \\
(0,021)\end{array}$ \\
\hline Gasto por aluno dos municípios & $\begin{array}{l}-0,000 \\
(0,000)\end{array}$ & $\begin{array}{c}0,000 \\
(0,000)\end{array}$ & $\begin{array}{c}-0,000 * * * \\
(0,000)\end{array}$ & $\begin{array}{c}-0,000^{* * * *} \\
(0,000)\end{array}$ & $\begin{array}{c}0,000 * * * \\
(0,000)\end{array}$ & $\begin{array}{c}0,000 * * * \\
(0,000)\end{array}$ \\
\hline Gasto por aluno dos estados & $\begin{array}{c}0,000^{* * *} * \\
(0,000)\end{array}$ & $\begin{array}{c}0,000 * * * \\
(0,000)\end{array}$ & $\begin{array}{c}-0,000^{* * *} * \\
(0,000)\end{array}$ & $\begin{array}{c}-0,000 * * * \\
(0,000)\end{array}$ & $\begin{array}{c}0,000 * * * \\
(0,000)\end{array}$ & $\begin{array}{c}0,000 * * * \\
(0,000)\end{array}$ \\
\hline Município beneficiário de recursos do FUNDEF & $\begin{array}{l}-0,003 \\
(0,007)\end{array}$ & $\begin{array}{l}-0,002 \\
(0,007)\end{array}$ & $\begin{array}{c}0,030 \text { *** } \\
(0,009)\end{array}$ & $\begin{array}{c}0,029 * * * \\
(0,009)\end{array}$ & $\begin{array}{c}-0,027 * * * \\
(0,007)\end{array}$ & $\begin{array}{c}-0,027 * * * * \\
(0,007)\end{array}$ \\
\hline Estado beneficiário de recursos do FUNDEF & $\begin{array}{c}0,001 \\
(0,005)\end{array}$ & $\begin{array}{c}0,000 \\
(0,005)\end{array}$ & $\begin{array}{c}-0,016^{* * *} * \\
(0,006)\end{array}$ & $\begin{array}{c}-0,016^{* * *} * \\
(0,006)\end{array}$ & $\begin{array}{c}0,015^{* * * *} \\
(0,004)\end{array}$ & $\begin{array}{c}0,015^{* * *} * \\
(0,004)\end{array}$ \\
\hline Controles & Sim & Sim & Sim & Sim & Sim & Sim \\
\hline Dummies de ano & Sim & Sim & Sim & Sim & Sim & Sim \\
\hline $\mathrm{R}$ quadrado ajustado & 0,021 & 0,027 & 0,027 & 0,029 & 0,027 & 0,027 \\
\hline Observações & 23.352 & 23.308 & 23.352 & 23.308 & 23.352 & 23.308 \\
\hline
\end{tabular}

a As colunas de número 1 apresentam os resultados obtidos por meio da estimação da equação (26) por efeitos fixos para os alunos matriculados na $1^{a}$ série.

${ }^{\mathrm{b}}$ As colunas de número 2 apresentam os resultados obtidos por meio da estimação da equação (26) por efeitos fixos para os alunos matriculados na $1^{a}$ série, com a inclusão de distorção idade-série como controle.

***significante a $1 \%, * *$ significante a $5 \%$ e $*$ significante a $10 \%$

Como pode ser observado, os resultados apresentados são semelhantes, o que sugere que o impacto negativo dos primeiros anos de descentralização não decorreu da absorção de crianças com idade superior à recomendada para a série. Ainda assim, para a primeira série, a descentralização está associada à piora dos indicadores educacionais avaliados ${ }^{71}$.

Por outro lado, a piora inicial dos indicadores de rendimento pode estar relacionada a adoção do regime de ciclos por algumas escolas do grupo de comparação ${ }^{72}$. Em 1999, observa-se que $29,8 \%$ das escolas do estado e apenas $5,8 \%$ das escolas municipais adotavam o regime de ci-

\footnotetext{
${ }^{71}$ É possível que as crianças ingressantes nas escolas do grupo de tratamento, apesar de apresentarem idade ideal para matrícula, tivessem rendimento inferior.

${ }^{72}$ Não foi possível acompanhar a evolução da adoção do regime de ciclos pelas escolas dos grupos de tratamento e comparação. Para o período estudado, o INEP só divulgou essa variável em 1999. Dessa forma, a tendência no tempo dos indicadores educacionais avaliados pode diferir entre os grupos de tratamento e comparação. Por exemplo, é possível que as taxas de aprovação das escolas que permaneceram sob gestão do estado já apresentassem tendência crescente.
} 
$\operatorname{clos}^{73}$. Para a amostra estudada, no mesmo ano, 72,6\% das escolas tratadas e 42,7\% das escolas do grupo de comparação adotavam o regime de séries, respectivamente ${ }^{74}$.

Por um lado, os resultados apresentados na Tabela 12 indicam que os municípios estavam despreparados para absorver maior proporção de alunos do ensino fundamental. Contudo, os resultados também sugerem que existe um período de acomodação para que os novos métodos de ensino e políticas empregadas pela gestão municipal apresentem algum impacto. Após 4 anos de descentralização, os resultados indicam queda das taxas de reprovação. Em relação ao grupo de comparação, estima-se que as escolas descentralizadas apresentaram taxas de reprovação $0,042 \%$ e $0,068 \%$ inferiores após 4 e 5 anos de descentralização, respectivamente ${ }^{75}$.

Existem três questionamentos principais quanto à consistência dos estimadores apresentados. Primeiramente, é possível que tenham sido omitidas características, variantes no tempo, dos grupos de tratamento e comparação que estejam correlacionadas com a descentralização e com os indicadores educacionais avaliados; em segundo lugar, os grupos de tratamento e comparação podem apresentar tendências diferentes no tempo; e iii) podem existir fatores que afetem o tratamento diferentemente dos controles.

Sobre o primeiro questionamento, é importante ressaltar que, além de características dos estabelecimentos de ensino, também estão incluídas na análise diversas variáveis de controle no âmbito das escolas e dos municípios. Como a metodologia de diferença em diferenças pressupõe que a única diferença entre os grupos de tratamento e comparação é a exposição ao tratamento avaliado, deve-se considerar que as escolas que permaneceram sob gestão do estado também estão sujeitas à menor autonomia de gasto imposta com a implantação do FUNDEF. Nesse sentido, para essas escolas, o indicador de dependência fiscal corresponde à relação entre recursos oriundos do FUNDEF e despesas com educação e cultura no âmbito do governo estadual. Para as escolas descentralizadas, utilizou-se a mesma variável existente no âmbito dos governos municipais.

Similarmente à análise do impacto da municipalização realizado anteriormente, a redistribuição de recursos, entre determinado estado e seus municípios e entre municípios ricos e pobres

\footnotetext{
${ }^{73} \mathrm{Em} 2003$, as porcentagens são de $26,2 \%$ e 8,3\%, respectivamente.

${ }^{74}$ Os números apresentados indicam que a adoção do regime de ciclos é mais intensa no âmbito dos governos estaduais. Em 2003, 66\% das escolas tratadas e 45,9\% das escolas do grupo de comparação adotavam o regime de séries.

${ }^{75} \mathrm{O}$ impacto do quarto ano de descentralização na taxa de reprovação é significante a $10 \%$ de significância.
} 
de um mesmo estado, é levada em consideração por meio da evolução do gasto por aluno no âmbito do governo estadual, para as escolas do grupo de comparação, e no âmbito do governo municipal, para as escolas do grupo de tratamento. Por fim, as escolas estaduais e as escolas descentralizadas foram classificadas entre as que se localizam em estados e municípios "doadores" ou "beneficiários" dos recursos do FUNDEF.

Sobre o segundo questionamento, as colunas de número 2 da Tabela (12) apresentam o resultado da estimação de um modelo que permite tendências não lineares específicas para o grupo de comparação. As estimativas encontradas são, em sua maioria, semelhantes às apresentadas nas colunas de número 1, o que sugere que tendências não lineares, especificas para o grupo de comparação, não são relevantes para explicar os indicadores de rendimento auferidos por este grupo.

Por fim, quanto ao terceiro questionamento, incluem-se dummies de interações entre os estados e os anos estudados na amostra de escolas do grupo de comparação. A inclusão de tais variáveis específicas para as escolas que permaneceram sob a gestão do estado permite controlar políticas ocorridas no âmbito desses governos que tenham afetado as escolas do grupo de comparação diferentemente das escolas do grupo de tratamento.

Os resultados para o novo modelo proposto estão apresentados nas colunas de número 3 da Tabela (12). As estimativas sugerem efeitos negativos para descentralização apenas no que se refere à taxa de abandono. Além disso, os resultados encontrados fornecem evidências de que a estimação principal apresentada, colunas de número 1, subestimavam os impactos positivos para a descentralização após 4 e 5 anos de descentralização. De tal modo, existem indícios de que para o para o período em análise, algumas políticas adotadas no âmbito dos governos estaduais afetaram o grupo de comparação quanto aos indicadores de rendimento e distorção idade-série por ele auferidos.

Nesse contexto, após um período de acomodação e uma piora inicial dos indicadores, os resultados apresentados fornecem evidências de que a descentralização apresentou, em média, efeitos positivos no que concerne à redução das taxas de reprovação. Ao considerar que as escolas do grupo de tratamento, em relação ao grupo de comparação, adotavam majoritariamente o regime de séries, as estimativas encontradas estão possivelmente subestimadas. De tal modo, existem indicativos de que os efeitos positivos da descentralização são superiores aos apresentados. 
Ademais, os resultados apresentados nas colunas 1 e 2 da Tabela 12 fornecem evidências de que as externalidades positivas, associadas à alocação de recursos do FUNDEF, parecem ter contrabalanceado os efeitos negativos da perda de autonomia local quanto à aplicação dos recursos. Por outro lado, no âmbito dos governos estaduais, estima-se que a maior rigidez de gasto implique piora nos indicadores educacionais avaliados.

\subsection{Interação entre descentralização e renda per capita}

A literatura teórica prevê que o impacto da descentralização está associado ao contexto do local em que foi aplicada e com os indivíduos a ela sujeitos. Pressupõem-se efeitos benéficos em regiões nas quais os governos locais tenham habilidade técnica e capacitação comparável à gestão central e onde os moradores tenham maior instrução política para fiscalizar e exigir seus direitos. Por outro lado, em regiões mal administradas e com população menos instruída, é razoável esperar impactos negativos para a descentralização. Nesse caso, descentralizar a responsabilidade da prestação de serviços públicos a entes federativos com menor capacitação possivelmente implicará piora do bem estar dos indivíduos dado que, até então, a gestão centralizada garantia um nível mínimo de serviços.

Dessa forma, semelhantemente ao trabalho realizado por Galiani, Gertler e Schargrodsky (2008), propõe-se a estimação de um modelo com a interação entre as dummies descentralização e dois grupos de municípios: os que apresentam menor renda per capita (inferior a um salário mínimo de 2000) e os que apresentam maior renda per capita (superior a um salário mínimo ${ }^{76}$ de 2000). A reprodução do estudo para a amostra de municípios brasileiros fornece evidências semelhantes ao ocorrido na Argentina. Como pode ser observado na Tabela 14, os efeitos positivos da descentralização estão restritos aos municípios com maiores níveis de renda per capita. Embora os resultados indiquem que um ano de gestão descentralizada implicou piora dos indicadores educacionais avaliados nos dois grupos de municípios, após 2 anos de gestão descentralizada os efeitos negativos persistem apenas nos municípios com menores níveis de renda ${ }^{77}$. Para esse grupo municípios, a descentralização está associada a maiores taxas de abandono e de distorção idade-série e a menores taxas de aprovação nos dois primeiros anos de gestão descentralizada.

\footnotetext{
${ }^{76}$ A renda per capita foi obtida no Censo Demográfico de 2000. Dessa forma, utilizou-se o salário mínimo desse ano como base para separação dos municípios.

${ }^{77}$ Para o primeiro ano de descentralização os resultados apresentados indicam aumento na taxa de abandono nos dois grupos de municípios. Para o grupo de municípios com menores níveis de renda per capita, os resultados também sugerem que, após um ano de descentralização, houve queda na taxa de aprovação.
} 
Tabela 14: Interação entre descentralização e renda per capita $\left(1^{a}\right.$ a $4^{a}$ série $)$

\begin{tabular}{|c|c|c|c|c|}
\hline & Tx. de abandono & Tx. de aprovação & Tx. de reprovação & $\begin{array}{l}\text { Tx. de distorção } \\
\text { idade-série }\end{array}$ \\
\hline 1 ano de descentralização*Menor renda per capita & $\begin{array}{c}0,042 * * * \\
(0,015)\end{array}$ & $\begin{array}{c}-0,040 * * \\
(0,019)\end{array}$ & $\begin{array}{l}-0,002 \\
(0,014)\end{array}$ & $\begin{array}{c}0,044 * * * \\
(0,016)\end{array}$ \\
\hline 2 anos de descentralização*Menor renda per capita & $\begin{array}{l}0,035^{*} \\
(0,021)\end{array}$ & $\begin{array}{c}-0,056^{* * *} \\
(0,028)\end{array}$ & $\begin{array}{c}0,021 \\
(0,020)\end{array}$ & $\begin{array}{c}0,048^{* *} \\
(0,023)\end{array}$ \\
\hline 3 anos de descentralização*Menor renda per capita & $\begin{array}{c}0,034 \\
(0,028)\end{array}$ & $\begin{array}{l}-0,046 \\
(0,038)\end{array}$ & $\begin{array}{c}0,013 \\
(0,026)\end{array}$ & $\begin{array}{c}0,033 \\
(0,031)\end{array}$ \\
\hline 4 anos de descentralização*Menor renda per capita & $\begin{array}{c}0,011 \\
(0,037)\end{array}$ & $\begin{array}{l}-0,014 \\
(0,049)\end{array}$ & $\begin{array}{c}0,002 \\
(0,034)\end{array}$ & $\begin{array}{c}0,030 \\
(0,040)\end{array}$ \\
\hline 5 anos de descentralização*Menor renda per capita & $\begin{array}{l}-0,003 \\
(0,046)\end{array}$ & $\begin{array}{c}0,016 \\
(0,061)\end{array}$ & $\begin{array}{l}-0,014 \\
(0,042)\end{array}$ & $\begin{array}{c}0,012 \\
(0,050)\end{array}$ \\
\hline 1 ano de descentralização*Maior renda per capita & $\begin{array}{c}0,051^{* * * *} \\
(0,016)\end{array}$ & $\begin{array}{c}-0,043^{* * *} \\
(0,019)\end{array}$ & $\begin{array}{l}-0,008 \\
(0,014)\end{array}$ & $\begin{array}{l}0,033^{*} \\
(0,018)\end{array}$ \\
\hline 2 anos de descentralização*Maior renda per capita & $\begin{array}{c}0,034 \\
(0,021)\end{array}$ & $\begin{array}{l}-0,019 \\
(0,025)\end{array}$ & $\begin{array}{l}-0,015 \\
(0,017)\end{array}$ & $\begin{array}{c}0,017 \\
(0,024)\end{array}$ \\
\hline 3 anos de descentralização*Maior renda per capita & $\begin{array}{c}0,021 \\
(0,027)\end{array}$ & $\begin{array}{c}0,028 \\
(0,032)\end{array}$ & $\begin{array}{c}-0,050 * * \\
(0,021)\end{array}$ & $\begin{array}{c}0,007 \\
(0,032)\end{array}$ \\
\hline 4 anos de descentralização*Maior renda per capita & $\begin{array}{c}0,018 \\
(0,033)\end{array}$ & $\begin{array}{c}0,060 \\
(0,040)\end{array}$ & $\begin{array}{c}-0,078 * * * \\
(0,026)\end{array}$ & $\begin{array}{l}-0,025 \\
(0,040)\end{array}$ \\
\hline 5 anos de descentralização*Maior renda per capita & $\begin{array}{c}0,017 \\
(0,040)\end{array}$ & $\begin{array}{l}0,095 * * \\
(0,048)\end{array}$ & $\begin{array}{c}-0,112 * * * \\
(0,031)\end{array}$ & $\begin{array}{l}-0,059 \\
(0,048)\end{array}$ \\
\hline Dependência fiscal dos municípios & $\begin{array}{l}-0,013 \\
(0,013)\end{array}$ & $\begin{array}{l}0,030^{*} \\
(0,017)\end{array}$ & $\begin{array}{l}-0,017 \\
(0,013)\end{array}$ & $\begin{array}{c}-0,037 * * * \\
(0,014)\end{array}$ \\
\hline Dependência fiscal dos estados & $\begin{array}{c}0,047 * * * \\
(0,016)\end{array}$ & $\begin{array}{l}-0,036^{*} \\
(0,021)\end{array}$ & $\begin{array}{l}-0,011 \\
(0,015)\end{array}$ & $\begin{array}{c}0,049 * * * \\
(0,019)\end{array}$ \\
\hline Gasto por aluno dos municípios & $\begin{array}{l}-0,000 \\
(0,000)\end{array}$ & $\begin{array}{l}-0,000 \\
(0,000)\end{array}$ & $\begin{array}{c}0,000 \\
(0,000)\end{array}$ & $\begin{array}{c}-0,000 * * \\
(0,000)\end{array}$ \\
\hline Gasto por aluno dos estados & $\begin{array}{c}0,000^{* * * *} \\
(0,000)\end{array}$ & $\begin{array}{c}-0,000 * * * \\
(0,000)\end{array}$ & $\begin{array}{l}-0,000 \\
(0,000)\end{array}$ & $\begin{array}{c}0,000 \\
(0,000)\end{array}$ \\
\hline Município beneficiário de recursos do FUNDEF & $\begin{array}{c}-0,007 * * \\
(0,003)\end{array}$ & $\begin{array}{c}0,014 * * * \\
(0,005)\end{array}$ & $\begin{array}{l}-0,007^{*} \\
(0,004)\end{array}$ & $\begin{array}{l}-0,001 \\
(0,004)\end{array}$ \\
\hline Estado beneficiário de recursos do FUNDEF & $\begin{array}{c}-0,014 * * * \\
(0,003)\end{array}$ & $\begin{array}{c}0,016 * * * \\
(0,003)\end{array}$ & $\begin{array}{l}-0,002 \\
(0,002)\end{array}$ & $\begin{array}{l}-0,005 \\
(0,003)\end{array}$ \\
\hline Controles & Sim & Sim & Sim & Sim \\
\hline Dummies de ano & Sim & Sim & Sim & Sim \\
\hline $\mathrm{R}$ quadrado ajustado & 0,026 & 0,022 & 0,010 & 0,072 \\
\hline Observações & 42.808 & 42.808 & 42.808 & 37.806 \\
\hline
\end{tabular}

${ }^{a}$ Menor renda per capita é uma dummy igual a 1 se o município apresentava, em 2000, renda per capita inferior a um salário mínimo (R\$ 151,00).

b Maior renda per capita é uma dummy igual a 1 se o município apresentava, em 2000, renda per capita superior ou igual a um salário mínimo $(\mathrm{R} \$ 151,00)$.

***significante a $1 \%, * *$ significante a $5 \%$ e *significante a $10 \%$ 
Se por um lado a descentralização implica diminuição das taxas de reprovação no grupo de municípios com maiores níveis de renda per capita, e por outro parece ter apresentado efeitos perversos no grupo de municípios com menores níveis de renda, existem evidências de que esse processo resultou aumento da desigualdade dos resultados educacionais ${ }^{78}$. Dentre os fatores que podem explicar os resultados apresentados, como já ressaltado, a alocação eficiente dos recursos em uma gestão descentralizada está associada à capacitação do governo local e a consciência política da população.

Nesse sentido, é provável que o estabelecimento dos Conselhos de Acompanhamento e Controle Social, nos municípios com maior renda per capita, esteja associado à aplicação correta dos recursos advindos do FUNDEF. Ademais, esse grupo de municípios já apresentava, antes da municipalização observada no final da década de 90, os melhores indicadores de rendimento, o que sugere que estavam mais bem preparados para absorver um maior número de alunos.

\subsection{Interação entre descentralização e Lei de Responsabilidade Fiscal}

De acordo com a Lei de Responsabilidade Fiscal (LRF), na esfera municipal, o limite máximo para a realização de despesas com pessoal como percentual da Receita Corrente Líquida $(\mathrm{RCL})^{79}$ é de $60 \%$. O descumprimento com os limites estabelecidos acarreta a suspensão de transferências voluntárias, a contratação de operações de crédito e a concessão de garantias para a obtenção de empréstimos.

Com intuito de verificar se os impactos da descentralização estão associados ao fato de os municípios apresentarem menor proporção de despesas com pessoal, em relação à RCL, propõese a interação entre as dummies de descentralização e o inverso da relação entre despesas com pessoal e RCL. Os resultados apresentados na Tabela 15 sugerem que os impactos positivos para a descentralização são superiores em municípios com menores proporções de gasto com pessoal em relação à RCL.

\footnotetext{
${ }^{78}$ A Tabela 24, apresentada no Apêndice A.2 deste trabalho, mostra o impacto da descentralização separadamente para os grupos de escolas que apresentavam, em 1997, as menores e as maiores taxas de abandono. Os resultados encontrados sugerem que descentralização, embora esteja associada à queda das taxas de abandono nos municípios que apresentavam as melhores escolas, está relacionada ao aumento da taxa de abandono no grupo de municípios que apresentada os maiores índices de evasão.

${ }^{79}$ Distribuídos da seguinte forma: i) $6 \%$ para o Legislativo, incluído o Tribunal de Contas, quando houver; e ii) $54 \%$ para o Poder Executivo.
} 
Tabela 15: Interação entre descentralização e inverso da relação entre gastos com pessoal e Receita Corrente Líquida ( $1^{a}$ a $4^{a}$ série)

\begin{tabular}{|c|c|c|c|c|}
\hline & Tx. de abandono & Tx. de aprovação & Tx. de reprovação & $\begin{array}{c}\text { Tx. de distorção } \\
\text { idade-série }\end{array}$ \\
\hline \multirow[t]{2}{*}{1 ano de descentralização } & $0,002 *$ & 0,001 & $-0,004 * * *$ & $0,005 * * *$ \\
\hline & $(0,001)$ & $(0,002)$ & $(0,001)$ & $(0,001)$ \\
\hline \multirow[t]{2}{*}{2 anos de descentralização } & $-0,001$ & $-0,003 *$ & $0,004 * * *$ & $0,003 * *$ \\
\hline & $(0,001)$ & $(0,002)$ & $(0,001)$ & $(0,001)$ \\
\hline \multirow[t]{2}{*}{3 anos de descentralização } & $-0,003 * * *$ & $0,003 * * *$ & 0,000 & $-0,001$ \\
\hline & $(0,000)$ & $(0,000)$ & $(0,000)$ & $(0,002)$ \\
\hline \multirow[t]{2}{*}{4 anos de descentralização } & $-0,004 * *$ & $0,006 * * *$ & $-0,002 * *$ & $-0,006^{* *}$ \\
\hline & $(0,002)$ & $(0,002)$ & $(0,001)$ & $(0,002)$ \\
\hline \multirow[t]{2}{*}{5 anos de descentralização } & $-0,004$ & $0,010^{* * *}$ & $-0,007 * * *$ & $-0,016^{* * *}$ \\
\hline & $(0,003)$ & $(0,003)$ & $(0,002)$ & $(0,004)$ \\
\hline \multirow[t]{2}{*}{ Dependência fiscal dos municípios } & $-0,003$ & 0,023 & $-0,020 *$ & $-0,036^{* * *}$ \\
\hline & $(0,011)$ & $(0,015)$ & $(0,012)$ & $(0,014)$ \\
\hline \multirow[t]{2}{*}{ Dependência fiscal dos estados } & $-0,003$ & $0,032 * *$ & $-0,029 * * *$ & $0,041 * *$ \\
\hline & $(0,010)$ & $(0,014)$ & $(0,010)$ & $(0,018)$ \\
\hline \multirow[t]{2}{*}{ Gasto por aluno dos municípios } & 0,000 & $-0,000 * *$ & $0,000^{* *}$ & $-0,000 * *$ \\
\hline & $(0,000)$ & $(0,000)$ & $(0,000)$ & $(0,000)$ \\
\hline \multirow[t]{2}{*}{ Gasto por aluno dos estados } & $0,000 * * *$ & $-0,000$ & $-0,000 * * *$ & 0,000 \\
\hline & $(0,000)$ & $(0,000)$ & $(0,000)$ & $(0,000)$ \\
\hline \multirow[t]{2}{*}{ Município beneficiário de recursos do FUNDEF } & $-0,008 * *$ & $0,017 * * *$ & $-0,009 * *$ & $-0,003$ \\
\hline & $(0,003)$ & $(0,005)$ & $(0,004)$ & $(0,004)$ \\
\hline \multirow[t]{2}{*}{ Estado beneficiário de recursos do FUNDEF } & $-0,014 * * *$ & $0,015^{* * * *}$ & $-0,002$ & $-0,004$ \\
\hline & $(0,003)$ & $(0,003)$ & $(0,002)$ & $(0,003)$ \\
\hline Controles & Sim & Sim & Sim & Sim \\
\hline Dummies de ano & Sim & Sim & Sim & Sim \\
\hline $\mathrm{R}$ quadrado ajustado & 0,025 & 0,020 & 0,010 & 0,069 \\
\hline Observações & 42.762 & 42.762 & 42.762 & 37.806 \\
\hline
\end{tabular}

a As dummies de descentralização foram interagidas com o inverso do parâmetro da Lei de Responsabilidade Fiscal que determina que as despesas com pessoal não devem ultrapassar $60 \%$ da RCL.

***significante a $1 \%, * *$ significante a $5 \%$ e *significante a $10 \%$

Semelhantemente aos resultados já apresentados, esse modelo também sugere piora inicial nos indicadores educacionais avaliados ${ }^{80}$. Contudo, a partir do terceiro ano de gestão descentralizada, existem evidências de que as escolas do grupo de tratamento, comparativamente às escolas que permaneceram sob gestão estadual, apresentaram taxas de abandono, de reprovação e de distorção idade-série inferiores e taxas de aprovação superiores. Ademais, os efeitos positivos para a descentralização são potencializados em municípios com menores proporções de despesas com pessoal em relação à RCL.

\footnotetext{
${ }^{80}$ Com exceção para a taxa de reprovação.
} 


\section{CONCLUSÕES}

Este trabalho procurou avaliar os impactos da expansão da gestão municipal no primeiro ciclo do ensino fundamental, sobretudo no que concerne à transferência de gestão de algumas escolas estaduais para a administração municipal, nos indicadores de rendimento e de distorção idadesérie auferidos por alunos de $1^{a}$ a $4^{a}$ série. Embora a municipalização seja, em tese, uma ideia boa por pressupor a adequação da disponibilização da educação às necessidades peculiares de cada região, a análise dos dados do Censo Escolar corrobora a hipótese de que esse processo não constituiu uma transferência organizada de alunos entre as redes de ensino. Observa-se que os municípios matricularam os alunos da forma como podiam, por exemplo, por meio do número de alunos por escola municipal, sem necessariamente ter havido maior preocupação com a qualidade da educação oferecida.

Contrariando a literatura teórica que prevê efeitos benéficos para a descentralização da educação, o aumento da proporção de matrículas de $1^{a}$ a $4^{a}$ série em escolas municipais estão refletidos em maiores taxas de abandono e de reprovação e menores taxas de aprovação. De tal modo, é possível argumentar que a maior parte dos municípios não estava preparada para absorver maior proporção de alunos do ensino fundamental. Nesse sentido, embora as Secretarias Municipais de Educação estejam mais próximas da população e consigam verificar com mais facilidade suas necessidades, esses órgãos apresentam menor capacitação técnica que as Secretarias Estaduais. Seria razoável esperar efeitos positivos se os municípios já tivessem maior experiência com a gestão do ensino fundamental e se o processo de municipalização fosse caracterizado por uma transferência organizada de alunos entre as redes de ensino.

Por outro lado, existem evidências de que a descentralização de algumas escolas estaduais, após um período de acomodação e uma piora inicial dos indicadores, implicou queda nas taxas de reprovação. Existem indicativos de que os efeitos positivos concentram-se em municípios com maiores níveis de renda per capita. Esse grupo de municípios já apresentava, antes da municipalização observada no final da década de 90, os melhores indicadores de rendimento, o que sugere que estavam mais bem preparados para absorver um maior número de alunos. No entanto, os impactos negativos prevalecem em municípios com menores níveis de renda per capita, o que corrobora a hipótese de que os efeitos da descentralização variam de acordo com o contexto do local em que a política foi aplicada. De tal modo, é possível argumentar que houve aumento da desigualdade dos resultados educacionais. 
Quanto à maior rigidez de gasto imposta pelo FUNDEF, no âmbito dos governos municipais, as externalidades positivas associadas aos recursos do Fundo parecem ter contrabalanceado a perda de autonomia local. Destacam-se, por exemplo, a exclusividade dos recursos do Fundo ao pagamento de professores em efetivo exercício e o estabelecimento de conselhos para fiscalização do uso das verbas. Nesse contexto, por exemplo, o estabelecimento de Conselhos de Acompanhamento e Controle Social pode estar associado à correta aplicação dos recursos advindos do FUNDEF. Já no âmbito dos estados, a maior dependência fiscal está relacionada à piora dos indicadores de rendimento, o que indica que as regras impostas pelo Fundo parecem ter sido contrárias às preferências locais.

De acordo com as conclusões apresentadas, é possível argumentar que a descentralização da educação, para que seja bem sucedida, requer maior capacitação dos municípios para que transfiram organizadamente os alunos entre as redes de ensino. Ressalta-se que os efeitos positivos da descentralização, concentram-se em municípios que já apresentavam os melhores resultados educacionais e os maiores níveis de renda per capita. Essa constatação revela que os municípios, com maior habilidade quanto ao fornecimento de uma educação de qualidade e uma população mais bem instruída para fiscalizar os seus direitos, estão mais propensos a obterem efeitos positivos com a descentralização. Ademais, as regras do FUNDEF mostram como imposições para a aplicação dos recursos podem ser benéficas, ainda que estejam relacionadas à menor autonomia de gasto. 


\section{REFERÊNCIAS BIBLIOGRÁFICAS}

BANCO MUNDIAL. Educação municipal no Brasil: recursos, incentivos e resultados. Banco Mundial: Estados Unidos da América, 2002.

BARANKAY, I.; LOCKWOOD, B. Decentralization and the productive efficiency of government: Evidence from swiss cantons. Journal of Public Economics, Elsevier, v. 91, n. 5, p. 1197-1218, 2007.

BARDHAN, P.; MOOKHERJEE, D. Decentralizing antipoverty program delivery in developing countries. Journal of Public Economics, Elsevier, v. 89, n. 4, p. 675-704, 2005.

BIRD, R.; VAILLANCOURT, F. Fiscal decentralization in developing countries. Cambridge: Cambridge University Press, 2008.

BLUNDELL, R.; DIAS, M. Alternative approaches to evaluation in empirical microeconomics. Portuguese Economic Journal, Springer, v. 1, n. 2, p. 91-115, 2002.

CHANNA, A.; FAGUET, J.-P. Decentralization of health and education in developing countries: a quality-adjusted review of the empirical literature. Economic organisation and public policy discussion papers, 2012.

D’ATRI, F. Municipalização do Ensino Fundamental da Rede Pública: Os Impactos sobre o Desempenho Escolar. 2007.

DRAIBE, S. et al. Brasil, o sistema de proteção social e suas transformações recentes. [S.l.]: Naciones Unidas, Comisión Económica para América Latina y El Caribe, 1993.

FAGUET, J.; SANCHEZ, F. Decentralization's effects on educational outcomes in bolivia and colombia. World Development, Elsevier, v. 36, n. 7, p. 1294-1316, 2008.

GALIANI, S.; GERTLER, P.; SCHARGRODSKY, E. School decentralization: Helping the good get better, but leaving the poor behind. Journal of Public Economics, v. 92, n. 10-11, p. 2106-2120, October 2008.

HECKMAN, J. J.; HOTZ, V. J. Choosing among alternative nonexperimental methods for estimating the impact of social programs: The case of manpower training. Journal of the American statistical Association, Taylor \& Francis Group, v. 84, n. 408, p. 862-874, 1989.

JONES, M.; SANGUINETTI, P.; TOMMASI, M. Politics, institutions, and fiscal performance in a federal system: an analysis of the argentine provinces. Journal of Development Economics, Elsevier, v. 61, n. 2, p. 305-333, 2000.

LEME, M.; PAREDES, R.; SOUZA, A. A municipalização do ensino fundamental e seu impacto sobre a proficiência no brasil. Rio de Janeiro, Elsevier, 2009.

MADEIRA, R. The Effects of Decentralization on Schooling: Evidence From the Sao Paulo Statems Education Reform. São Paulo, 2007.

MANOR, J. The political economy of democratic decentralization. Washington, D.C: World Bank, 1999. 
MENEZES-FILHO, N. A. et al. Trade unions and the economic performance of brazilian establishments. Estudos Econômicos (São Paulo), Scielo Brasil, v. 38, n. 1, p. 55-72, 2008.

ORELLANO, V. et al. Descentralização fiscal e municipalização do ensino fundamental: impacto sobre os indicadores de desempenho educacional. 2011.

RAZO, R. O impacto da municipalização no Ensino Fundamental Brasileira: Uma avaliação da Técnica de Avaliação de Impacto de matching por diferenças em diferenças. 2004.

RODRIGUEZ, C. Households schooling behavior and political economy trade-offs after decentralization”. Universidad de Boston, 2006.

SMITH, B. Decentralization: the territorial dimension of the state. London: Allen \& Unwin London, 1985.

SOARES, S.; SOUZA, A. O demografia das escolas: decomposição da municipalização do ensino básico. Rio de Janeiro: Ipea, 2003.

WALLIS, J.; OATES, W. Decentralization in the public sector: An empirical study of state and local government. In: Fiscal federalism: Quantitative studies. Chicago: University of Chicago Press, 1988. p. 5-32.

WOOLDRIDGE, J. What's new in econometrics? Imbens/Wooldridge lecture notes; summer institute 2007, lecture 10: Difference-in-differences estimation. 2007a.

WOOLDRIDGE, J. What's new in econometrics? Imbens/Wooldridge lecture notes; summer institute 2007, lecture 8: Cluster and Stratified Sampling. 2007b.

WOOLDRIDGE, J. M. Econometric analysis of cross section and panel data. London: The MIT press, 2002. 


\section{APÊNDICES}

A.1 Estatísticas descritivas 
Tabela 16: Estatísticas descritivas dos municípios da amostra (1997 e 2002)

\begin{tabular}{|c|c|c|}
\hline & 1997 & 2002 \\
\hline \multicolumn{3}{|l|}{ Indicadores de rendimento } \\
\hline Taxa de abandono & $\begin{array}{c}0,095 * * * \\
(0,001)\end{array}$ & $\begin{array}{c}0,066^{* * * *} \\
(0,001)\end{array}$ \\
\hline Taxa de reprovação & $\begin{array}{c}0,133 \\
(0,001)\end{array}$ & $\begin{array}{c}0,133 \\
(0,001)\end{array}$ \\
\hline Taxa de aprovação & $\begin{array}{c}0,772 * * * \\
(0,002)\end{array}$ & $\begin{array}{c}0,799 * * * \\
(0,002)\end{array}$ \\
\hline Taxa de distorção idade-série & $\begin{array}{c}0,425 * * * \\
(0,003)\end{array}$ & $\begin{array}{c}0,329 * * * \\
(0,002)\end{array}$ \\
\hline \multicolumn{3}{|l|}{ Características das escolas } \\
\hline Relação de recursos por sala & $\begin{array}{c}0,277 * * * \\
(0,023)\end{array}$ & $\begin{array}{c}0,433 * * * \\
(0,004)\end{array}$ \\
\hline Proporção de escolas com bibliotecas & $\begin{array}{c}0,201 * * * \\
(0,004)\end{array}$ & $\begin{array}{c}0,291 * * * \\
(0,004)\end{array}$ \\
\hline Proporção de escolas com laboratórios & $\begin{array}{c}0,061 * * * \\
(0,002)\end{array}$ & $\begin{array}{c}0,101 * * * \\
(0,003)\end{array}$ \\
\hline Proporção de escolas com Merenda Escolar & $\begin{array}{c}0,886^{* * * *} \\
(0,003)\end{array}$ & $\begin{array}{c}0,990 * * * \\
(0,001)\end{array}$ \\
\hline Proporção de escolas com Livro Didático & $\begin{array}{c}0,945 * * * \\
(0,002)\end{array}$ & $\begin{array}{c}0,984 * * * \\
(0,001)\end{array}$ \\
\hline Proporção de escolas com Dinheiro Direto na Escola & $\begin{array}{c}0,400 * * * \\
(0,005)\end{array}$ & $\begin{array}{c}0,662 * * * \\
(0,004)\end{array}$ \\
\hline Proporção de escolas com Transporte escolar & $\begin{array}{c}0,122 * * * \\
(0,003)\end{array}$ & $\begin{array}{c}0,300 * * * \\
(0,005)\end{array}$ \\
\hline Proporção de escolas com Programa de Tecnologia Educacional & $\begin{array}{c}0,046^{* * * *} \\
(0,002)\end{array}$ & $\begin{array}{c}0,022 * * * \\
(0,001)\end{array}$ \\
\hline Número de alunos por turma & $\begin{array}{l}24,572 \\
(0,099)\end{array}$ & $\begin{array}{l}24,452 \\
(0,076)\end{array}$ \\
\hline Proporção de docentes com ensino superior & $\begin{array}{c}0,164 * * * \\
(0,003)\end{array}$ & $\begin{array}{c}0,245^{* * * *} \\
(0,003)\end{array}$ \\
\hline Proporção de escolas com acesso à energia elétrica & $\begin{array}{c}0,676^{* * * *} \\
(0,004)\end{array}$ & $\begin{array}{c}0,833 * * * \\
(0,003)\end{array}$ \\
\hline Proporção de escolas com acesso à água encanada & $\begin{array}{c}0,906 * * * \\
(0,003)\end{array}$ & $\begin{array}{c}0,985^{* * *} * \\
(0,001)\end{array}$ \\
\hline Proporção de escolas com acesso ao saneamento básico & $\begin{array}{c}0,813 * * * \\
(0,004)\end{array}$ & $\begin{array}{c}0,917 * * * \\
(0,003)\end{array}$ \\
\hline Proporção de escolas em áreas urbanas & $\begin{array}{c}0,325 * * * \\
(0,004)\end{array}$ & $\begin{array}{c}0,411 * * * \\
(0,004)\end{array}$ \\
\hline \multicolumn{3}{|l|}{$\begin{array}{l}\text { Características dos } \\
\text { municípios e dos estados }\end{array}$} \\
\hline Gasto por aluno municipal (em R\$) & $\begin{array}{c}386,605 * * * \\
(3,993)\end{array}$ & $\begin{array}{c}586,006^{* * * *} \\
(4,705)\end{array}$ \\
\hline Gasto por aluno estadual (em R $\$$ ) & $\begin{array}{c}499,647 * * * \\
(2,180)\end{array}$ & $\begin{array}{c}663,216 * * * \\
(4,510)\end{array}$ \\
\hline PIB per capita (em R $\$$ ) & $\begin{array}{c}3.227,632 * * * \\
(49,923)\end{array}$ & $\begin{array}{c}2.704,654 * * * \\
(40,898)\end{array}$ \\
\hline População (em número de habitantes) & $\begin{array}{l}29.006,722 \\
(2.377,281)\end{array}$ & $\begin{array}{l}31.603,773 \\
(2.625,509)\end{array}$ \\
\hline Numero de alunos das escolas municipais & $\begin{array}{c}152,670 * * * \\
(2,233)\end{array}$ & $\begin{array}{c}219,832 * * * \\
(2,138)\end{array}$ \\
\hline Número de alunos das escolas estaduais & $\begin{array}{c}292,946 * * * \\
(2,264)\end{array}$ & $\begin{array}{c}220,749 \text { *** } \\
(2,193)\end{array}$ \\
\hline Proporção de matrículas municipais & $\begin{array}{c}0,533 * * * \\
(0,004)\end{array}$ & $\begin{array}{c}0,749 * * * \\
(0,003)\end{array}$ \\
\hline Proporção de escolas municipais & $\begin{array}{c}0,729 * * * \\
(0,004)\end{array}$ & $\begin{array}{c}0,814 * * * \\
(0,003)\end{array}$ \\
\hline $\begin{array}{l}\text { Relação entre gasto com educação } \\
\text { e cultura e gasto total - Gov Municipal }\end{array}$ & $\begin{array}{c}0,261 * * * \\
(0,001)\end{array}$ & $\begin{array}{c}0,294 * * * \\
(0,001)\end{array}$ \\
\hline $\begin{array}{l}\text { Relação entre gasto com educação } \\
\text { e cultura e gasto total - Gov Estadual }\end{array}$ & $\begin{array}{c}0,149 * * * \\
(0,001)\end{array}$ & $\begin{array}{c}0,186 * * * \\
(0,000)\end{array}$ \\
\hline Relação entre gasto com pessoal e RCL & $\begin{array}{c}0,426 * * * \\
(0,002)\end{array}$ & $\begin{array}{c}0,404 * * * \\
(0,001)\end{array}$ \\
\hline
\end{tabular}

***significante a $1 \%, * *$ significante a $5 \%$ e *significante a $10 \%$ 
Tabela 17: Estatísticas descritivas dos grupos de tratamento e de comparação após a descentralização (2002)

\begin{tabular}{|c|c|c|}
\hline & Grupo de comparação & Grupo de tratamento \\
\hline \multicolumn{3}{|l|}{ Indicadores de rendimento } \\
\hline Taxa de abandono & $\begin{array}{c}0,088 \\
(0,002)\end{array}$ & $\begin{array}{c}0,091 \\
(0,002)\end{array}$ \\
\hline Taxa de reprovação & $\begin{array}{c}0,116^{* * * *} \\
(0,001)\end{array}$ & $\begin{array}{c}0,153 * * * \\
(0,002)\end{array}$ \\
\hline Taxa de aprovação & $\begin{array}{c}0,796 * * * \\
(0,002)\end{array}$ & $\begin{array}{c}0,756^{* * * *} \\
(0,002)\end{array}$ \\
\hline Taxa de distorção idade-série & $\begin{array}{c}0,377 * * * \\
(0,003)\end{array}$ & $\begin{array}{c}0,459 * * * \\
(0,003)\end{array}$ \\
\hline \multicolumn{3}{|l|}{ Características das escolas } \\
\hline Total de funcionários por escola & $\begin{array}{c}33,450 * * * \\
(0,416)\end{array}$ & $\begin{array}{c}15,353^{* * * *} \\
(0,240)\end{array}$ \\
\hline Proporção de meninas matriculadas & $\begin{array}{c}0,472 * * * \\
(0,001)\end{array}$ & $\begin{array}{c}0,468 * * * \\
(0,001)\end{array}$ \\
\hline Relação de recursos por sala & $\begin{array}{c}0,479 * * * \\
(0,005)\end{array}$ & $\begin{array}{c}0,320 * * * \\
(0,005)\end{array}$ \\
\hline Proporção de escolas com bibliotecas & $\begin{array}{c}0,471 * * * \\
(0,006)\end{array}$ & $\begin{array}{c}0,211 * * * \\
(0,006)\end{array}$ \\
\hline Proporção de escolas com laboratórios & $\begin{array}{c}0,154 * * * \\
(0,005)\end{array}$ & $\begin{array}{c}0,034 * * * \\
(0,003)\end{array}$ \\
\hline Proporção de escolas com Merenda Escolar & $\begin{array}{c}0,989 \\
(0,001)\end{array}$ & $\begin{array}{c}0,989 \\
(0,001)\end{array}$ \\
\hline Proporção de escolas com Livro Didático & $\begin{array}{c}0,990 * * * \\
(0,001)\end{array}$ & $\begin{array}{c}0,983 * * * \\
(0,002)\end{array}$ \\
\hline Proporção de escolas com Dinheiro Direto na Escola & $\begin{array}{c}0,730 * * * \\
(0,006)\end{array}$ & $\begin{array}{c}0,680 * * * \\
(0,007)\end{array}$ \\
\hline Proporção de escolas com Transporte escolar & $\begin{array}{c}0,154 * * * \\
(0,005)\end{array}$ & $\begin{array}{c}0,261 * * * \\
(0,006)\end{array}$ \\
\hline Proporção de escolas com Programa de Tecnologia Educacional & $\begin{array}{c}0,061 * * * \\
(0,003)\end{array}$ & $\begin{array}{c}0,008 * * * \\
(0,001)\end{array}$ \\
\hline Número de alunos por turma & $\begin{array}{c}26,634 * * * \\
(0,148)\end{array}$ & $\begin{array}{c}23,100^{* * * *} \\
(0,134)\end{array}$ \\
\hline Número de turmas por escola & $\begin{array}{c}6,403 * * * \\
(0,071)\end{array}$ & $\begin{array}{c}4,617 * * * \\
(0,079)\end{array}$ \\
\hline Proporção de docentes com ensino superior & $\begin{array}{c}0,267 * * * \\
(0,004)\end{array}$ & $\begin{array}{c}0,130 * * * \\
(0,004)\end{array}$ \\
\hline Proporção de escolas com acesso à energia elétrica & $\begin{array}{c}0,922 * * * \\
(0,003)\end{array}$ & $\begin{array}{c}0,834 * * * \\
(0,005)\end{array}$ \\
\hline Proporção de escolas com acesso à água encanada & $\begin{array}{c}0,988 * * \\
(0,001)\end{array}$ & $\begin{array}{c}0,983^{* *} \\
(0,002)\end{array}$ \\
\hline Proporção de escolas com acesso ao saneamento básico & $\begin{array}{c}0,945^{* * * *} \\
(0,003)\end{array}$ & $\begin{array}{c}0,931 * * * \\
(0,004)\end{array}$ \\
\hline Proporção de escolas em áreas urbanas & $\begin{array}{c}0,702 * * * \\
(0,006)\end{array}$ & $\begin{array}{c}0,378 * * * \\
(0,007)\end{array}$ \\
\hline Número de alunos por escola & $\begin{array}{c}198,917 * * * \\
(2,376)\end{array}$ & $\begin{array}{c}140,193 * * * \\
(2,309)\end{array}$ \\
\hline \multicolumn{3}{|l|}{$\begin{array}{l}\text { Características dos } \\
\text { municípios e dos estados }\end{array}$} \\
\hline Gasto por aluno estadual (Em R\$) & $\begin{array}{c}605,018 * * * \\
(3,773)\end{array}$ & $\begin{array}{c}478,327 * * * \\
(3,442)\end{array}$ \\
\hline PIB per capita (Em R\$) & $\begin{array}{c}2.960,511 * * * \\
(31,479)\end{array}$ & $\begin{array}{c}2.239,915 * * * \\
(45,305)\end{array}$ \\
\hline População (Em número de habitantes) & $\begin{array}{c}236.220,288^{* * * *} \\
(6.930,651)\end{array}$ & $\begin{array}{c}76.456,990 * * * \\
(4.120,655)\end{array}$ \\
\hline $\begin{array}{l}\text { Relação entre gasto com educação } \\
\text { e cultura e gasto total }\end{array}$ & $\begin{array}{c}0,170 * * * \\
(0,001)\end{array}$ & $\begin{array}{c}0,316^{* * *} \\
(0,001)\end{array}$ \\
\hline $\begin{array}{l}\text { Relação entre transferências do FUNDEF } \\
\text { e gastos com educação e cultura }\end{array}$ & $\begin{array}{c}0,381 * * * \\
(0,002)\end{array}$ & $\begin{array}{c}0,482 * * * \\
(0,003)\end{array}$ \\
\hline Proporção de beneficiários do FUNDEF & $\begin{array}{c}0,038^{* * *} \\
(0,002)\end{array}$ & $\begin{array}{c}0,696 * * * \\
(0,007)\end{array}$ \\
\hline
\end{tabular}

$* * *$ significante a $1 \%, * *$ significante a $5 \%$ e $*$ significante a $10 \%$ 
A.2 Modelos estimados 
Tabela 18: Impactos da municipalização por efeitos fixos e por primeiras diferenças $\left(1^{a}\right.$ a $4^{a}$ série $)$

\begin{tabular}{|c|c|c|c|c|c|c|c|c|}
\hline & \multicolumn{2}{|c|}{ Tx. de abandono } & \multicolumn{2}{|c|}{ Tx. de aprovação } & \multicolumn{2}{|c|}{ Tx. de reprovação } & \multicolumn{2}{|c|}{$\begin{array}{l}\text { Tx. de distorção } \\
\text { idade-série }\end{array}$} \\
\hline & EF & PD & $\mathrm{EF}$ & PD & $\mathrm{EF}$ & PD & $\mathrm{EF}$ & PD \\
\hline Proporção de matrícula municipal & $\begin{array}{c}0,033 * * * \\
(0,007)\end{array}$ & $\begin{array}{c}0,038^{* * * *} \\
(0,007)\end{array}$ & $\begin{array}{c}-0,082 * * * \\
(0,011)\end{array}$ & $\begin{array}{c}-0,077 * * * \\
(0,011)\end{array}$ & $\begin{array}{c}0,047 * * * \\
(0,008)\end{array}$ & $\begin{array}{c}0,039 * * * \\
(0,008)\end{array}$ & $\begin{array}{c}-0,022^{*} \\
(0,012)\end{array}$ & $\begin{array}{c}0,009 \\
(0,011)\end{array}$ \\
\hline Proporção de escolas municipais & $\begin{array}{c}-0,016^{* * * *} \\
(0,005)\end{array}$ & $\begin{array}{c}-0,014 * * \\
(0,007)\end{array}$ & $\begin{array}{l}-0,008 \\
(0,010)\end{array}$ & $\begin{array}{c}0,004 \\
(0,011)\end{array}$ & $\begin{array}{c}0,026^{* * * *} \\
(0,008)\end{array}$ & $\begin{array}{c}0,003 \\
(0,007)\end{array}$ & $\begin{array}{c}-0,024 * * \\
(0,010)\end{array}$ & $\begin{array}{l}-0,010 \\
(0,010)\end{array}$ \\
\hline Dependência fiscal dos municípios & $\begin{array}{c}0,006 \\
(0,004)\end{array}$ & $\begin{array}{c}0,007 \\
(0,005)\end{array}$ & $\begin{array}{c}0,013 * * \\
(0,006)\end{array}$ & $\begin{array}{l}-0,008 \\
(0,007)\end{array}$ & $\begin{array}{c}-0,015^{* * * *} \\
(0,004)\end{array}$ & $\begin{array}{c}0,003 \\
(0,004)\end{array}$ & $\begin{array}{c}0,010 \\
(0,007)\end{array}$ & $\begin{array}{c}0,026 * * * \\
(0,006)\end{array}$ \\
\hline Dependência fiscal dos estados & $\begin{array}{c}0,038 * * * \\
(0,006)\end{array}$ & $\begin{array}{c}0,057 * * * \\
(0,007)\end{array}$ & $\begin{array}{c}-0,033^{* * * *} \\
(0,010)\end{array}$ & $\begin{array}{c}-0,060 * * * \\
(0,011)\end{array}$ & $\begin{array}{l}-0,008 \\
(0,007)\end{array}$ & $\begin{array}{l}-0,001 \\
(0,008)\end{array}$ & $\begin{array}{c}0,060^{* * * *} \\
(0,012)\end{array}$ & $\begin{array}{c}-0,066^{* * * *} \\
(0,011)\end{array}$ \\
\hline Gasto por aluno dos municípios & $\begin{array}{c}-0,000^{* * *} \\
(0,000)\end{array}$ & $\begin{array}{c}-0,000^{* * * *} \\
(0,000)\end{array}$ & $\begin{array}{c}0,000 * * \\
(0,000)\end{array}$ & $\begin{array}{c}0,000 \\
(0,000)\end{array}$ & $\begin{array}{c}0,000 \\
(0,000)\end{array}$ & $\begin{array}{c}0,000 * * * \\
(0,000)\end{array}$ & $\begin{array}{l}0,000^{*} \\
(0,000)\end{array}$ & $\begin{array}{c}0,000 * * * \\
(0,000)\end{array}$ \\
\hline Gasto por aluno dos estados & $\begin{array}{c}-0,000^{* * * *} * \\
(0,000)\end{array}$ & $\begin{array}{c}0,000 * * * \\
(0,000)\end{array}$ & $\begin{array}{c}0,000 * * * \\
(0,000)\end{array}$ & $\begin{array}{l}-0,000^{*} \\
(0,000)\end{array}$ & $\begin{array}{l}-0,000 \\
(0,000)\end{array}$ & $\begin{array}{l}-0,000 \\
(0,000)\end{array}$ & $\begin{array}{c}0,000 * * * \\
(0,000)\end{array}$ & $\begin{array}{c}0,000 * * \\
(0,000)\end{array}$ \\
\hline Município beneficiário de recursos do Fundef & $\begin{array}{c}-0,001 \\
(0,001)\end{array}$ & $\begin{array}{l}-0,001 \\
(0,002)\end{array}$ & $\begin{array}{c}-0,001 \\
(0,002)\end{array}$ & $\begin{array}{c}0,002 \\
(0,002)\end{array}$ & $\begin{array}{c}0,001 \\
(0,001)\end{array}$ & $\begin{array}{c}-0,002 \\
(0,001)\end{array}$ & $\begin{array}{c}-0,004^{*} \\
(0,002)\end{array}$ & $\begin{array}{l}-0,004 * \\
(0,002)\end{array}$ \\
\hline Estado beneficiário de recursos do Fundef & $\begin{array}{l}-0,001 \\
(0,002)\end{array}$ & $\begin{array}{c}-0,005^{* *} \\
(0,002)\end{array}$ & $\begin{array}{c}0,006 * * * \\
(0,002)\end{array}$ & $\begin{array}{c}0,009 * * * \\
(0,002)\end{array}$ & $\begin{array}{c}-0,002^{*} \\
(0,001)\end{array}$ & $\begin{array}{l}-0,001 \\
(0,001)\end{array}$ & $\begin{array}{c}-0,014 * * * \\
(0,002)\end{array}$ & $\begin{array}{c}0,002 \\
(0,002)\end{array}$ \\
\hline Controles & Sim & Sim & Sim & Sim & Sim & Sim & Sim & Sim \\
\hline Dummies de ano & Sim & Sim & Sim & Sim & Sim & Sim & Sim & Sim \\
\hline $\mathrm{R}$ quadrado ajustado & 0,157 & 0,080 & 0,097 & 0,061 & 0,056 & 0,029 & 0,368 & 0,084 \\
\hline Número de observações & 21.461 & 15.753 & 21.461 & 15.753 & 21.461 & 15.753 & 21.461 & 15.753 \\
\hline
\end{tabular}

${ }^{\text {a }}$ Os estimadores de efeitos fixos e de primeiras diferenças implicam estimativas semelhantes para os impactos da expansão da matrícula municipal, com exceção da taxa de distorção idade-série.

\footnotetext{
***significante a $1 \%, * *$ significante a $5 \%$ e *significante a $10 \%$
} 
Tabela 19: Impactos da municipalização sem considerar o aumento do número de alunos por escolas $\left(1^{a}\right.$ a $4^{a}$ série)

\begin{tabular}{lccc}
\hline & Tx. de abandono & Tx. de aprovação & Tx. de reprovação \\
\hline Proporção de matrícula municipal & $0,013^{* *}$ & $-0,070^{* * *}$ & $0,052^{* * *}$ \\
Proporção de escolas municipais & $(0,005)$ & $(0,008)$ & $(0,006)$ \\
& $-0,001$ & $-0,017^{*}$ & $0,023^{* * *}$ \\
Dependência fiscal dos municípios & $(0,005)$ & $(0,009)$ & $(0,007)$ \\
& 0,004 & $0,014^{* *}$ & $-0,015^{* * *}$ \\
Dependência fiscal dos estados & $(0,004)$ & $(0,006)$ & $(0,004)$ \\
Gasto por aluno dos municípios & $0,035^{* * *}$ & $-0,031^{* * *}$ & $-0,007$ \\
& $(0,006)$ & $(0,010)$ & $(0,007)$ \\
Gasto por aluno dos estados & $-0,000^{* *}$ & $0,000^{* *}$ & 0,000 \\
& $(0,000)$ & $(0,000)$ & $(0,000)$ \\
Município beneficiário de recursos do FUNDEF & $-0,000^{* * *}$ & $0,000^{* * *}$ & $-0,000$ \\
Estado beneficiário de recursos do FUNDEF & $(0,000)$ & $(0,000)$ & $(0,000)$ \\
& $-0,001$ & $-0,001$ & 0,001 \\
Controles & $(0,001)$ & $(0,002)$ & $(0,001)$ \\
Dummies de ano & $-0,001$ & $0,006^{* * *}$ & $-0,003^{*}$ \\
& $(0,002)$ & $(0,002)$ & $(0,001)$ \\
R quadrado ajustado & Sim & Sim & Sim \\
Número de observações & Sim & Sim & Sim \\
a Para obtenção dos resim & & & \\
& 0,149 & 0,096 & 0,055 \\
& 21.461 & 21.461 & 21.461 \\
\hline
\end{tabular}

${ }^{a}$ Para obtenção dos resultados apresentados na Tabela 10 e na Tabela 11, as variáveis número de alunos por escola municipal e o número de alunos por escola estadual foram adicionadas como controles. A inclusão dessas variáveis tem o intuito de isolar o efeito da municipalização, com intuito de controlar a expansão do acesso ao ensino fundamental, ocorrida no final da década de 90 . Os resultados apresentados nesta tabela desconsideram tais controles.

$* * *$ significante a $1 \%, * *$ significante a $5 \%$ e *significante a $10 \%$ 
Tabela 20: Impactos da descentralização por efeitos fixos e por primeiras diferenças ( $1^{a}$ a $4^{a}$ série) - Equação (24)

\begin{tabular}{|c|c|c|c|c|c|c|c|c|}
\hline & \multicolumn{2}{|c|}{ Tx. de abandono } & \multicolumn{2}{|c|}{ Tx. de aprovação } & \multicolumn{2}{|c|}{ Tx. de reprovação } & \multicolumn{2}{|c|}{$\begin{array}{l}\text { Tx. de distorção } \\
\text { idade-série }\end{array}$} \\
\hline & $\mathrm{PD}$ & $\mathrm{EF}$ & PD & $\mathrm{EF}$ & $\mathrm{PD}$ & $\mathrm{EF}$ & PD & $\mathrm{EF}$ \\
\hline 1 ano de descentralização & $\begin{array}{c}0,034 * * * \\
(0,011)\end{array}$ & $\begin{array}{c}-0,014 * \\
(0,008)\end{array}$ & $\begin{array}{l}-0,022^{*} \\
(0,013)\end{array}$ & $\begin{array}{c}0,038 * * * \\
(0,010)\end{array}$ & $\begin{array}{l}-0,012 \\
(0,010)\end{array}$ & $\begin{array}{c}-0,023 * * * \\
(0,008)\end{array}$ & $\begin{array}{c}0,040 * * * \\
(0,013)\end{array}$ & $\begin{array}{c}0,014 \\
(0,012)\end{array}$ \\
\hline 2 anos de descentralização & $\begin{array}{l}0,021^{*} \\
(0,012)\end{array}$ & $\begin{array}{c}-0,032 * * * \\
(0,009)\end{array}$ & $\begin{array}{c}-0,031^{* *} \\
(0,014)\end{array}$ & $\begin{array}{c}0,027 * * * \\
(0,010)\end{array}$ & $\begin{array}{c}0,010 \\
(0,011)\end{array}$ & $\begin{array}{c}0,005 \\
(0,008)\end{array}$ & $\begin{array}{c}0,047 * * * \\
(0,014)\end{array}$ & $\begin{array}{c}0,020 \\
(0,013)\end{array}$ \\
\hline 3 anos de descentralização & $\begin{array}{c}0,015 \\
(0,012)\end{array}$ & $\begin{array}{c}-0,033^{* * * *} * \\
(0,009)\end{array}$ & $\begin{array}{l}-0,017 \\
(0,015)\end{array}$ & $\begin{array}{c}0,036 * * * \\
(0,011)\end{array}$ & $\begin{array}{c}0,002 \\
(0,011)\end{array}$ & $\begin{array}{l}-0,003 \\
(0,008)\end{array}$ & $\begin{array}{c}0,051 * * * * \\
(0,014)\end{array}$ & $\begin{array}{l}0,023^{*} \\
(0,013)\end{array}$ \\
\hline 4 anos de descentralização & $\begin{array}{c}0,008 \\
(0,013)\end{array}$ & $\begin{array}{c}-0,034 * * * \\
(0,009)\end{array}$ & $\begin{array}{l}-0,012 \\
(0,015)\end{array}$ & $\begin{array}{c}0,033 * * * \\
(0,011)\end{array}$ & $\begin{array}{c}0,003 \\
(0,011)\end{array}$ & $\begin{array}{c}0,001 \\
(0,008)\end{array}$ & $\begin{array}{c}0,050^{* * * *} \\
(0,015)\end{array}$ & $\begin{array}{c}0,022 \\
(0,013)\end{array}$ \\
\hline 5 anos de descentralização & $\begin{array}{c}0,006 \\
(0,013)\end{array}$ & $\begin{array}{c}-0,035 * * * \\
(0,009)\end{array}$ & $\begin{array}{l}-0,008 \\
(0,015)\end{array}$ & $\begin{array}{c}0,034 * * * \\
(0,011)\end{array}$ & $\begin{array}{c}0,003 \\
(0,011)\end{array}$ & $\begin{array}{c}0,001 \\
(0,008)\end{array}$ & $\begin{array}{c}0,045^{* * * *} \\
(0,015)\end{array}$ & $\begin{array}{c}0,017 \\
(0,013)\end{array}$ \\
\hline Controles & Sim & Sim & Sim & Sim & Sim & Sim & Sim & Sim \\
\hline Dummies de ano & Sim & Sim & Sim & Sim & Sim & Sim & Sim & Sim \\
\hline $\mathrm{R}$ quadrado ajustado & 0,025 & 0,031 & 0,020 & 0,028 & 0,009 & 0,017 & 0,058 & 0,051 \\
\hline Observações & 42.808 & 59.093 & 42.808 & 59.093 & 42.808 & 59.093 & 37.806 & 54.308 \\
\hline
\end{tabular}

***significante a $1 \%, * *$ significante a $5 \%$ e *significante a $10 \%$ 
Tabela 21: Impactos da descentralização por efeitos fixos e por primeiras diferenças ( $1^{a}$ a $4^{a}$ série) - Equação (26)

\begin{tabular}{|c|c|c|c|c|c|c|c|c|}
\hline & \multicolumn{2}{|c|}{ Tx. de abandono } & \multicolumn{2}{|c|}{ Tx. de aprovação } & \multicolumn{2}{|c|}{ Tx. de reprovação } & \multicolumn{2}{|c|}{$\begin{array}{l}\text { Tx. de distorçãa } \\
\text { idade-série }\end{array}$} \\
\hline & PD & $\mathrm{EF}$ & PD & $\mathrm{EF}$ & PD & $\mathrm{EF}$ & PD & $\mathrm{EF}$ \\
\hline 1 ano de descentralização & $\begin{array}{c}0,046^{* *} \\
(0,019)\end{array}$ & $\begin{array}{c}0,048 * * * \\
(0,014)\end{array}$ & $\begin{array}{l}-0,035 \\
(0,022)\end{array}$ & $\begin{array}{c}-0,043^{* *} \\
(0,017)\end{array}$ & $\begin{array}{l}-0,012 \\
(0,016)\end{array}$ & $\begin{array}{l}-0,005 \\
(0,013)\end{array}$ & $\begin{array}{c}0,057 * * * \\
(0,019)\end{array}$ & $\begin{array}{c}0,038^{* *} \\
(0,016)\end{array}$ \\
\hline 2 anos de descentralização & $\begin{array}{c}0,028 \\
(0,025)\end{array}$ & $\begin{array}{c}0,036^{* * *} \\
(0,018)\end{array}$ & $\begin{array}{l}-0,024 \\
(0,030)\end{array}$ & $\begin{array}{l}-0,038^{*} \\
(0,022)\end{array}$ & $\begin{array}{l}-0,004 \\
(0,021)\end{array}$ & $\begin{array}{c}0,002 \\
(0,015)\end{array}$ & $\begin{array}{l}0,050^{*} \\
(0,026)\end{array}$ & $\begin{array}{c}0,030 \\
(0,020)\end{array}$ \\
\hline 3 anos de descentralização & $\begin{array}{c}0,012 \\
(0,033)\end{array}$ & $\begin{array}{c}0,028 \\
(0,022)\end{array}$ & $\begin{array}{c}0,011 \\
(0,039)\end{array}$ & $\begin{array}{l}-0,007 \\
(0,027)\end{array}$ & $\begin{array}{l}-0,023 \\
(0,027)\end{array}$ & $\begin{array}{l}-0,022 \\
(0,018)\end{array}$ & $\begin{array}{c}0,039 \\
(0,034)\end{array}$ & $\begin{array}{c}0,019 \\
(0,025)\end{array}$ \\
\hline 4 anos de descentralização & $\begin{array}{l}-0,006 \\
(0,042)\end{array}$ & $\begin{array}{c}0,017 \\
(0,027)\end{array}$ & $\begin{array}{c}0,046 \\
(0,050)\end{array}$ & $\begin{array}{c}0,025 \\
(0,033)\end{array}$ & $\begin{array}{l}-0,040 \\
(0,034)\end{array}$ & $\begin{array}{c}-0,042^{*} \\
(0,022)\end{array}$ & $\begin{array}{c}0,020 \\
(0,044)\end{array}$ & $\begin{array}{l}-0,001 \\
(0,031)\end{array}$ \\
\hline 5 anos de descentralização & $\begin{array}{l}-0,018 \\
(0,052)\end{array}$ & $\begin{array}{c}0,011 \\
(0,032)\end{array}$ & $\begin{array}{c}0,080 \\
(0,061)\end{array}$ & $\begin{array}{c}0,057 \\
(0,040)\end{array}$ & $\begin{array}{l}-0,062 \\
(0,042)\end{array}$ & $\begin{array}{c}-0,068 * * * \\
(0,026)\end{array}$ & $\begin{array}{l}-0,008 \\
(0,055)\end{array}$ & $\begin{array}{l}-0,029 \\
(0,037)\end{array}$ \\
\hline Dependência fiscal dos municípios & $\begin{array}{c}-0,030^{* * *} \\
(0,015)\end{array}$ & $\begin{array}{l}-0,019 \\
(0,012)\end{array}$ & $\begin{array}{l}0,042 * * \\
(0,019)\end{array}$ & $\begin{array}{c}0,044 * * * \\
(0,016)\end{array}$ & $\begin{array}{l}-0,012 \\
(0,015)\end{array}$ & $\begin{array}{c}-0,025^{* *} \\
(0,013)\end{array}$ & $\begin{array}{c}-0,042 * * * \\
(0,015)\end{array}$ & $\begin{array}{c}-0,037 \text { *** } \\
(0,014)\end{array}$ \\
\hline Dependência fiscal dos estados & $\begin{array}{c}0,053 * * * \\
(0,020)\end{array}$ & $\begin{array}{c}0,046^{* * * *} \\
(0,016)\end{array}$ & $\begin{array}{l}-0,044^{*} \\
(0,026)\end{array}$ & $\begin{array}{l}-0,033 \\
(0,020)\end{array}$ & $\begin{array}{l}-0,009 \\
(0,020)\end{array}$ & $\begin{array}{l}-0,013 \\
(0,015)\end{array}$ & $\begin{array}{c}0,067 * * * \\
(0,022)\end{array}$ & $\begin{array}{c}0,049 * * * \\
(0,018)\end{array}$ \\
\hline Gasto por aluno dos municípios & $\begin{array}{l}-0,000 \\
(0,000)\end{array}$ & $\begin{array}{l}-0,000 \\
(0,000)\end{array}$ & $\begin{array}{l}-0,000 \\
(0,000)\end{array}$ & $\begin{array}{l}-0,000 \\
(0,000)\end{array}$ & $\begin{array}{c}0,000 \\
(0,000)\end{array}$ & $\begin{array}{l}0,000^{*} \\
(0,000)\end{array}$ & $\begin{array}{l}-0,000^{*} \\
(0,000)\end{array}$ & $\begin{array}{c}-0,000^{* * *} \\
(0,000)\end{array}$ \\
\hline Gasto por aluno dos estados & $\begin{array}{c}0,000 * * * \\
(0,000)\end{array}$ & $\begin{array}{c}0,000 * * * * \\
(0,000)\end{array}$ & $\begin{array}{c}-0,000^{* * * *} \\
(0,000)\end{array}$ & $\begin{array}{c}-0,000 * * * \\
(0,000)\end{array}$ & $\begin{array}{l}-0,000^{*} \\
(0,000)\end{array}$ & $\begin{array}{l}-0,000 \\
(0,000)\end{array}$ & $\begin{array}{c}0,000 * * * \\
(0,000)\end{array}$ & $\begin{array}{l}0,000 \\
(0,000)\end{array}$ \\
\hline Município beneficiário de recursos do Fundef & $\begin{array}{l}-0,006 \\
(0,004)\end{array}$ & $\begin{array}{c}-0,008 * * \\
(0,003)\end{array}$ & $\begin{array}{l}0,013 * * \\
(0,005)\end{array}$ & $\begin{array}{c}0,017 * * * \\
(0,005)\end{array}$ & $\begin{array}{l}-0,007^{*} \\
(0,004)\end{array}$ & $\begin{array}{c}-0,009 * * \\
(0,004)\end{array}$ & $\begin{array}{l}-0,003 \\
(0,004)\end{array}$ & $\begin{array}{l}-0,002 \\
(0,004)\end{array}$ \\
\hline Estado beneficiário de recursos do Fundef & $\begin{array}{c}-0,016^{* * *} \\
(0,004)\end{array}$ & $\begin{array}{c}-0,014 * * * \\
(0,003)\end{array}$ & $\begin{array}{c}0,016^{* * *} \\
(0,004)\end{array}$ & $\begin{array}{c}0,016^{* * * *} \\
(0,003)\end{array}$ & $\begin{array}{c}0,000 \\
(0,003)\end{array}$ & $\begin{array}{l}-0,002 \\
(0,002)\end{array}$ & $\begin{array}{c}-0,008^{* * *} \\
(0,003)\end{array}$ & $\begin{array}{c}-0,005^{*} \\
(0,003)\end{array}$ \\
\hline Controles & Sim & Sim & Sim & Sim & Sim & Sim & Sim & Sim \\
\hline Dummies de ano & Sim & Sim & $\operatorname{Sim}$ & Sim & $\operatorname{Sim}$ & Sim & $\mathrm{Sim}$ & Sim \\
\hline
\end{tabular}

a Esta tabela apresenta os resultados da estimação da equação 26 por efeitos fixos e por primeiras diferenças. As estimativas encontradas são semelhantes, 0 que indica que a inclusão de uma tendência específica para as escolas consegue controlar grande parte das características não observáveis que possam explicar a decisão dos prefeitos em descentralizar determinadas escolas estaduais.

$* * *$ significante a $1 \%, * *$ significante a $5 \%$ e $*$ significante a $10 \%$ 
Tabela 22: Impactos da descentralização sem considerar o aumento da matrícula nas escolas dos grupos de tratamento e de comparação $\left(1^{a}\right.$ a $4^{a}$ série)

\begin{tabular}{lcccc}
\hline & Tx. de abandono & Tx. de aprovação & Tx. de reprovação & $\begin{array}{c}\text { Tx. de distorção } \\
\text { idade-série }\end{array}$ \\
\hline ano de descentralização & & & & \\
& $0,046^{* * *}$ & $-0,042^{* *}$ & $-0,003$ & $0,035^{* *}$ \\
2 anos de descentralização & $(0,014)$ & $(0,017)$ & $(0,012)$ & $(0,016)$ \\
& $0,034^{*}$ & $-0,038^{*}$ & 0,004 & 0,028 \\
3 anos de descentralização & $(0,018)$ & $(0,022)$ & $(0,015)$ & $(0,020)$ \\
4 anos de descentralização & 0,028 & $-0,006$ & $-0,021$ & 0,019 \\
& $(0,022)$ & $(0,027)$ & $(0,018)$ & $(0,025)$ \\
5 anos de descentralização & 0,017 & 0,025 & $-0,042^{*}$ & 0,000 \\
& $(0,027)$ & $(0,033)$ & $(0,022)$ & $(0,031)$ \\
Dependência fiscal dos municípios & 0,013 & 0,056 & $-0,069^{* * *}$ & $-0,026$ \\
Dependência fiscal dos estados & $(0,032)$ & $(0,040)$ & $(0,026)$ & $(0,037)$ \\
& $-0,018$ & $0,044^{* * *}$ & $-0,026^{* *}$ & $-0,036^{* * *}$ \\
Gasto por aluno dos municípios & $(0,012)$ & $(0,016)$ & $(0,013)$ & $(0,014)$ \\
& $0,039^{* *}$ & $-0,030$ & $-0,008$ & $0,041^{* *}$ \\
Gasto por aluno dos estados & $(0,016)$ & $(0,020)$ & $(0,015)$ & $(0,018)$ \\
Município beneficiário de recursos do Fundef & $-0,000$ & $-0,000$ & $0,000^{*}$ & $-0,000^{* *}$ \\
Estado beneficiário de recursos do Fundef & $(0,000)$ & $(0,000)$ & $(0,000)$ & $(0,000)$ \\
& $0,000^{* * *}$ & $-0,000^{* * *}$ & $-0,000$ & 0,000 \\
Controles & $(0,000)$ & $(0,000)$ & $(0,000)$ & $(0,000)$ \\
Dummies de ano & $-0,009^{* *}$ & $0,017 * * *$ & $-0,008^{* *}$ & $-0,003$ \\
R quadrado ajustado & $(0,003)$ & $(0,005)$ & $(0,004)$ & $(0,004)$ \\
Observações & $-0,013^{* * *}$ & $0,015^{* * *}$ & $-0,003$ & $-0,004$ \\
\hline a E & $(0,003)$ & $(0,003)$ & $(0,002)$ & $(0,003)$ \\
Sim
\end{tabular}

${ }^{a}$ Esta tabela apresenta os resultados da estimação da equação (26) por efeitos fixos sem adicionar como controle o número de alunos matriculados nas escolas dos grupos de tratamento e de comparação. Semelhantemente a análise por municípios, a inclusão dessa variável tenta isolar o efeito da descentralização, de modo a controlar o aumento da matrícula observada no final da década de 90.

$* * *$ significante a $1 \%, * *$ significante a $5 \%$ e $*$ significante a $10 \%$ 
Tabela 23: Interação entre descentralização e dependência dos recursos do FUNDEF ( $1^{a}$ a $4^{a}$ série)

\begin{tabular}{|c|c|c|c|c|}
\hline & Tx. de abandono & Tx. de aprovação & Tx. de reprovação & $\begin{array}{l}\text { Tx. de distorção } \\
\text { idade-série }\end{array}$ \\
\hline 1 ano de descentralização*Pouco dependentes do Fundef & $\begin{array}{c}0,043 * * * \\
(0,014)\end{array}$ & $\begin{array}{c}-0,049 * * * \\
(0,017)\end{array}$ & $\begin{array}{c}0,006 \\
(0,013)\end{array}$ & $\begin{array}{c}0,041 * * \\
(0,018)\end{array}$ \\
\hline 2 anos de descentralização*Pouco dependentes do Fundef & $\begin{array}{c}0,018 \\
(0,018)\end{array}$ & $\begin{array}{l}-0,010 \\
(0,022)\end{array}$ & $\begin{array}{l}-0,008 \\
(0,017)\end{array}$ & $\begin{array}{c}0,033 \\
(0,025)\end{array}$ \\
\hline 3 anos de descentralização*Pouco dependentes do Fundef & $\begin{array}{c}0,000 \\
(0,024)\end{array}$ & $\begin{array}{l}0,048^{*} \\
(0,029)\end{array}$ & $\begin{array}{c}-0,048^{* *} \\
(0,022)\end{array}$ & $\begin{array}{c}0,035 \\
(0,034)\end{array}$ \\
\hline 4 anos de descentralização*Pouco dependentes do Fundef & $\begin{array}{l}-0,009 \\
(0,030)\end{array}$ & $\begin{array}{c}0,091 * * \\
(0,037)\end{array}$ & $\begin{array}{c}-0,082 * * * \\
(0,029)\end{array}$ & $\begin{array}{c}0,021 \\
(0,043)\end{array}$ \\
\hline 5 anos de descentralização*Pouco dependentes do Fundef & $\begin{array}{l}-0,014 \\
(0,036)\end{array}$ & $\begin{array}{c}0,141^{* * * *} \\
(0,045)\end{array}$ & $\begin{array}{c}-0,128 * * * \\
(0,035)\end{array}$ & $\begin{array}{l}-0,001 \\
(0,053)\end{array}$ \\
\hline 1 ano de descentralização*Muito dependentes do Fundef & $\begin{array}{c}0,040 * * * \\
(0,014)\end{array}$ & $\begin{array}{l}-0,026 \\
(0,017)\end{array}$ & $\begin{array}{l}-0,014 \\
(0,012)\end{array}$ & $\begin{array}{c}0,017 \\
(0,015)\end{array}$ \\
\hline 2 anos de descentralização*Muito dependentes do Fundef & $\begin{array}{l}0,034^{*} \\
(0,020)\end{array}$ & $\begin{array}{l}-0,036 \\
(0,024)\end{array}$ & $\begin{array}{c}0,002 \\
(0,016)\end{array}$ & $\begin{array}{c}0,002 \\
(0,020)\end{array}$ \\
\hline 3 anos de descentralização*Muito dependentes do Fundef & $\begin{array}{c}0,038 \\
(0,027)\end{array}$ & $\begin{array}{l}-0,033 \\
(0,033)\end{array}$ & $\begin{array}{l}-0,005 \\
(0,021)\end{array}$ & $\begin{array}{l}-0,022 \\
(0,028)\end{array}$ \\
\hline 4 anos de descentralização*Muito dependentes do Fundef & $\begin{array}{c}0,021 \\
(0,035)\end{array}$ & $\begin{array}{l}-0,008 \\
(0,043)\end{array}$ & $\begin{array}{l}-0,012 \\
(0,027)\end{array}$ & $\begin{array}{l}-0,045 \\
(0,036)\end{array}$ \\
\hline 5 anos de descentralização*Muito dependentes do Fundef & $\begin{array}{c}0,007 \\
(0,044)\end{array}$ & $\begin{array}{c}0,017 \\
(0,053)\end{array}$ & $\begin{array}{l}-0,024 \\
(0,034)\end{array}$ & $\begin{array}{l}-0,079^{*} \\
(0,045)\end{array}$ \\
\hline Dependência fiscal dos estados & $\begin{array}{c}0,046 * * * \\
(0,016)\end{array}$ & $\begin{array}{c}-0,043 * * \\
(0,020)\end{array}$ & $\begin{array}{c}-0,004 \\
(0,015)\end{array}$ & $\begin{array}{c}0,053 * * * \\
(0,019)\end{array}$ \\
\hline Gasto por aluno dos municípios & $\begin{array}{l}-0,000 \\
(0,000)\end{array}$ & $\begin{array}{c}0,000 \\
(0,000)\end{array}$ & $\begin{array}{c}0,000 \\
(0,000)\end{array}$ & $\begin{array}{l}-0,000^{*} \\
(0,000)\end{array}$ \\
\hline Gasto por aluno dos estados & $\begin{array}{c}0,000^{* * * *} \\
(0,000)\end{array}$ & $\begin{array}{c}-0,000 * * * \\
(0,000)\end{array}$ & $\begin{array}{l}-0,000 \\
(0,000)\end{array}$ & $\begin{array}{c}0,000 \\
(0,000)\end{array}$ \\
\hline Município beneficiário de recursos do Fundef & $\begin{array}{c}-0,008^{* *} \\
(0,003)\end{array}$ & $\begin{array}{c}0,011^{* *} \\
(0,005)\end{array}$ & $\begin{array}{l}-0,003 \\
(0,004)\end{array}$ & $\begin{array}{l}-0,004 \\
(0,004)\end{array}$ \\
\hline Estado beneficiário de recursos do Fundef & $\begin{array}{c}-0,014 * * * \\
(0,003)\end{array}$ & $\begin{array}{c}0,016 * * * \\
(0,003)\end{array}$ & $\begin{array}{l}-0,002 \\
(0,002)\end{array}$ & $\begin{array}{l}-0,005^{*} \\
(0,003)\end{array}$ \\
\hline Controles & Sim & Sim & Sim & Sim \\
\hline Dummies de ano & Sim & Sim & Sim & Sim \\
\hline $\begin{array}{l}\text { R quadrado ajustado } \\
\text { Observacões }\end{array}$ & $\begin{array}{c}0,026 \\
42.808\end{array}$ & $\begin{array}{c}0,023 \\
42.808\end{array}$ & $\begin{array}{c}0,011 \\
42.808\end{array}$ & $\begin{array}{c}0,071 \\
37.806\end{array}$ \\
\hline
\end{tabular}

${ }^{a}$ Esta tabela apresenta os resultados da interação entre descentralização e o indicador de dependência fiscal. Os resultados encontrados sugerem que os efeitos positivos para a descentralização concentram-se majoritariamente nos municípios pouco dependentes de recursos do FUNDEF (municípios que apresentam relação de $35,8 \%$ entre recursos oriundos do FUNDEF e despesas realizadas com educação e cultura).

b 35,8\% é a mediana, para os municípios da amostra, da relação entre recursos oriundos do FUNDEF e despesas realizadas com educação e cultura.

$$
* * * \text { significante a } 1 \%, * * \text { significante a } 5 \% \text { e } * \text { significante a } 10 \%
$$


Tabela 24: Interação entre descentralização e taxa de abandono $\left(1^{a}\right.$ a $4^{a}$ série $)$

\begin{tabular}{|c|c|c|c|c|c|}
\hline & & Tx. de abandono & Tx. de. aprovação & Tx. de reprovação & $\begin{array}{l}\text { Tx. de distorção } \\
\text { idade-série }\end{array}$ \\
\hline \multirow{7}{*}{$\begin{array}{l}\text { Municípios que } \\
\text { apresentavam as maiores } \\
\text { taxas de abandono em } \\
1997\end{array}$} & 1 ano de descentralização & $\begin{array}{c}0,088^{* * * *} \\
(0,013)\end{array}$ & $\begin{array}{c}-0,075 * * * \\
(0,017)\end{array}$ & $\begin{array}{l}-0,013 \\
(0,013)\end{array}$ & $\begin{array}{c}0,042^{* * *} \\
(0,016)\end{array}$ \\
\hline & 2 anos de descentralização & $0,096^{* * *}$ & $-0,090 * * *$ & $-0,006$ & $0,041^{* *}$ \\
\hline & 3 anos de descentralização & $\begin{array}{c}(0,016) \\
0,103 * * *\end{array}$ & $\begin{array}{c}(0,021) \\
-0,070 * * *\end{array}$ & $\begin{array}{l}(0,015) \\
-0,034 *\end{array}$ & $\begin{array}{c}(0,020) \\
0,020\end{array}$ \\
\hline & & $(0,020)$ & $(0,026)$ & $(0,018)$ & $(0,025)$ \\
\hline & 4 anos de descentralização & $\begin{array}{c}0,093^{* * * *} \\
(0,025)\end{array}$ & $\begin{array}{c}-0,042 \\
(0,031)\end{array}$ & $\begin{array}{c}-0,051^{* *} \\
(0,022)\end{array}$ & $\begin{array}{c}0,005 \\
(0,031)\end{array}$ \\
\hline & 5 anos de descentralização & $\begin{array}{c}0,104 * * * \\
(0,030)\end{array}$ & $\begin{array}{l}-0,029 \\
(0,038)\end{array}$ & $\begin{array}{c}-0,075 * * * \\
(0,027)\end{array}$ & $\begin{array}{l}-0,024 \\
(0,038)\end{array}$ \\
\hline & 1 ano de descentralização & $\begin{array}{l}-0,015 \\
(0,013)\end{array}$ & $\begin{array}{c}0,006 \\
(0,017)\end{array}$ & $\begin{array}{c}0,009 \\
(0,013)\end{array}$ & $\begin{array}{l}0,031^{*} \\
(0,016)\end{array}$ \\
\hline \multirow{14}{*}{$\begin{array}{l}\text { Municípios que } \\
\text { apresentavam as menores } \\
\text { taxas de abandono em } \\
1997\end{array}$} & 2 anos de descentralização & $\begin{array}{c}-0,032^{* *} \\
(0,016)\end{array}$ & $\begin{array}{c}0,019 \\
(0,021)\end{array}$ & $\begin{array}{c}0,013 \\
(0,015)\end{array}$ & $\begin{array}{c}0,020 \\
(0,020)\end{array}$ \\
\hline & 3 anos de descentralização & $\begin{array}{c}-0,045^{* *} \\
(0,020)\end{array}$ & $\begin{array}{c}0,054 * * \\
(0,025)\end{array}$ & $\begin{array}{c}-0,009 \\
(0,018)\end{array}$ & $\begin{array}{c}0,018 \\
(0,025)\end{array}$ \\
\hline & 4 anos de descentralização & $\begin{array}{l}-0,036 \\
(0,024)\end{array}$ & $\begin{array}{l}0,071^{* *} \\
(0,031)\end{array}$ & $\begin{array}{l}-0,035 \\
(0,022)\end{array}$ & $\begin{array}{l}-0,003 \\
(0,031)\end{array}$ \\
\hline & 5 anos de descentralização & $\begin{array}{l}-0,038 \\
(0,030)\end{array}$ & $\begin{array}{c}0,103 * * * \\
(0,038)\end{array}$ & $\begin{array}{c}-0,065^{* *} \\
(0,026)\end{array}$ & $\begin{array}{l}-0,029 \\
(0,038)\end{array}$ \\
\hline & Dependência fiscal dos municípios & $\begin{array}{c}-0,045^{* * * *} \\
(0,011)\end{array}$ & $\begin{array}{c}0,064 * * * \\
(0,015)\end{array}$ & $\begin{array}{l}-0,019 \\
(0,013)\end{array}$ & $\begin{array}{c}-0,040 * * * \\
(0,014)\end{array}$ \\
\hline & Dependência fiscal dos estados & $\begin{array}{c}0,024 \\
(0,015)\end{array}$ & $\begin{array}{c}-0,016 \\
(0,020)\end{array}$ & $\begin{array}{c}-0,008 \\
(0,015)\end{array}$ & $\begin{array}{c}0,047 * * \\
(0,018)\end{array}$ \\
\hline & Gasto por aluno dos municípios & $\begin{array}{c}0,000 \\
(0,000)\end{array}$ & $\begin{array}{c}-0,000 * * \\
(0,000)\end{array}$ & $\begin{array}{c}0,000 \\
(0,000)\end{array}$ & $\begin{array}{c}-0,000^{* * *} \\
(0,000)\end{array}$ \\
\hline & Gasto por aluno dos estados & $\begin{array}{c}0,000^{* * * *} \\
(0,000)\end{array}$ & $\begin{array}{c}-0,000 * * * * \\
(0,000)\end{array}$ & $\begin{array}{l}-0,000 \\
(0,000)\end{array}$ & $\begin{array}{c}0,000 \\
(0,000)\end{array}$ \\
\hline & Município beneficiário de recursos do Fundef & $\begin{array}{c}-0,009 * * * \\
(0,003)\end{array}$ & $\begin{array}{c}0,017 * * * \\
(0,004)\end{array}$ & $\begin{array}{c}-0,008 * * \\
(0,004)\end{array}$ & $\begin{array}{l}-0,002 \\
(0,004)\end{array}$ \\
\hline & Estado beneficiário de recursos do Fundef & $\begin{array}{c}-0,014 * * * \\
(0,003)\end{array}$ & $\begin{array}{c}0,015^{* * * *} \\
(0,003)\end{array}$ & $\begin{array}{l}-0,002 \\
(0,002)\end{array}$ & $\begin{array}{l}-0,005 \\
(0,003)\end{array}$ \\
\hline & Controles & Sim & Sim & Sim & Sim \\
\hline & Dummies de ano & Sim & Sim & Sim & Sim \\
\hline & $\mathrm{R}$ quadrado ajustado & 0,136 & 0,072 & 0,013 & 0,072 \\
\hline & Observações & 42.808 & 42.808 & 42.808 & 37.806 \\
\hline
\end{tabular}

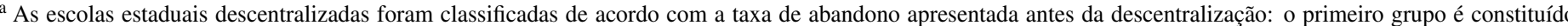
por escolas que apresentam taxa de abandono superior a 8,06\% (mediana da distribuição da taxa de abandono das escolas descentralizadas antes da descentralizaça), por escolicas descentralizadas antes da descentralizaçã), 0 segundo por escolas que apresentam taxa de abandono abaixo desse valor. Os resultados apresentados nesta tabela indicam que a descentralização acarretou aumento da desigualdade educacional. Existem evidências de aumento das taxas de abandono nas escolas que já apresentavam, antes da descentralização, evasão mais elevada. Po outro lado, os resultados sugerem queda nas taxas de abandono para o grupo de escolas que apresentavam as menores taxas de evasão em 1997.

$* * *$ significante a $1 \%, * *$ significante a $5 \%$ e $*$ significante a $10 \%$ 
Tabela 25: Interação entre descentralização e o montante de recursos recebidos do FUNDEF $\left(1^{a}\right.$ a $4^{a}$ série $)$

\begin{tabular}{|c|c|c|c|c|}
\hline & Tx. de abandono & Tx. de aprovação & Tx. de reprovação & $\begin{array}{l}\text { Tx. de distorção } \\
\text { idade-série }\end{array}$ \\
\hline 1 ano de descentralização * Fundef & $\begin{array}{l}-0,000 \\
(0,000)\end{array}$ & $\begin{array}{l}0,001 * * \\
(0,001)\end{array}$ & $\begin{array}{c}-0,001 * * * \\
(0,000)\end{array}$ & $\begin{array}{l}-0,000 \\
(0,000)\end{array}$ \\
\hline 2 anos de descentralização $*$ Fundef & $\begin{array}{c}-0,001 * * \\
(0,001)\end{array}$ & $\begin{array}{c}0,000 \\
(0,001)\end{array}$ & $\begin{array}{l}0,001^{*} \\
(0,001)\end{array}$ & $\begin{array}{l}-0,001 \\
(0,001)\end{array}$ \\
\hline 3 anos de descentralização *Fundef & $\begin{array}{c}-0,003^{* * *} \\
(0,001)\end{array}$ & $\begin{array}{c}0,004 * * * \\
(0,001)\end{array}$ & $\begin{array}{l}-0,001 \\
(0,001)\end{array}$ & $\begin{array}{c}-0,003 * * \\
(0,001)\end{array}$ \\
\hline 4 anos de descentralização $*$ Fundef & $\begin{array}{c}-0,005^{* * *} * \\
(0,001)\end{array}$ & $\begin{array}{c}0,006 * * * \\
(0,002)\end{array}$ & $\begin{array}{l}-0,000 \\
(0,001)\end{array}$ & $\begin{array}{c}-0,005^{* * * *} \\
(0,002)\end{array}$ \\
\hline 5 anos de descentralização $*$ Fundef & $\begin{array}{c}-0,007 * * * * \\
(0,002)\end{array}$ & $\begin{array}{c}0,007 * * * * \\
(0,002)\end{array}$ & $\begin{array}{l}-0,000 \\
(0,002)\end{array}$ & $\begin{array}{c}-0,005^{* *} \\
(0,002)\end{array}$ \\
\hline Dependência fiscal dos municípios & $\begin{array}{l}-0,006 \\
(0,011)\end{array}$ & $\begin{array}{c}0,007 \\
(0,014)\end{array}$ & $\begin{array}{l}-0,001 \\
(0,011)\end{array}$ & $\begin{array}{l}-0,022^{*} \\
(0,011)\end{array}$ \\
\hline Dependência fiscal dos estados & $\begin{array}{l}-0,015^{*} \\
(0,009)\end{array}$ & $\begin{array}{c}0,024 * * \\
(0,012)\end{array}$ & $\begin{array}{l}-0,009 \\
(0,009)\end{array}$ & $\begin{array}{l}-0,000 \\
(0,011)\end{array}$ \\
\hline Gasto por aluno dos municípios & $\begin{array}{c}0,000 \\
(0,000)\end{array}$ & $\begin{array}{c}-0,000 * * * \\
(0,000)\end{array}$ & $\begin{array}{c}0,000 * * * \\
(0,000)\end{array}$ & $\begin{array}{l}-0,000 \\
(0,000)\end{array}$ \\
\hline Gasto por aluno dos estados & $\begin{array}{c}0,000 * * * \\
(0,000)\end{array}$ & $\begin{array}{c}-0,000 * * \\
(0,000)\end{array}$ & $\begin{array}{l}-0,000 \\
(0,000)\end{array}$ & $\begin{array}{l}-0,000^{*} \\
(0,000)\end{array}$ \\
\hline Município beneficiário de recursos do Fundef & $\begin{array}{c}-0,009^{* *} \\
(0,003)\end{array}$ & $\begin{array}{c}0,017 * * * \\
(0,005)\end{array}$ & $\begin{array}{c}-0,008^{* *} \\
(0,004)\end{array}$ & $\begin{array}{l}-0,001 \\
(0,004)\end{array}$ \\
\hline Estado beneficiário de recursos do Fundef & $\begin{array}{c}-0,015^{* * *} * \\
(0,003)\end{array}$ & $\begin{array}{c}0,014 * * * \\
(0,003)\end{array}$ & $\begin{array}{c}0,001 \\
(0,002)\end{array}$ & $\begin{array}{l}-0,004 \\
(0,003)\end{array}$ \\
\hline Controles & Sim & Sim & Sim & Sim \\
\hline Dummies de ano & Sim & Sim & Sim & Sim \\
\hline $\begin{array}{l}\text { R quadrado ajustado } \\
\text { Observações }\end{array}$ & $\begin{array}{c}0,025 \\
42.808\end{array}$ & $\begin{array}{c}0,020 \\
42.808\end{array}$ & $\begin{array}{c}0,007 \\
42.808\end{array}$ & $\begin{array}{c}0,070 \\
37.806\end{array}$ \\
\hline
\end{tabular}

descentralização estão relacionados ao montante de recursos recebidos do Fundo.

$* * *$ significante a $1 \%, * *$ significante a $5 \%$ e *significante a $10 \%$ 
Tabela 26: Impactos da descentralização nas taxas de abandono por faixas de descentralização $\left(1^{a}\right.$ a $4^{a}$ série $)$

\begin{tabular}{|c|c|c|c|c|c|}
\hline & \multicolumn{5}{|c|}{ Municípios que descentralizaram: } \\
\hline & $\begin{array}{c}\text { desc. menos } \\
\text { de } 20 \% \\
\text { das escolas } \\
\text { estaduais }\end{array}$ & $\begin{array}{c}\text { desc. entre } \\
20 \% \text { e } 40 \% \\
\text { das escolas } \\
\text { estaduais }\end{array}$ & $\begin{array}{c}\text { desc. entre } \\
40 \% \text { e } 60 \% \\
\text { das escolas } \\
\text { estaduais }\end{array}$ & $\begin{array}{c}\text { desc. entre } \\
60 \% \text { e } 80 \% \\
\text { das escolas } \\
\text { estaduais }\end{array}$ & $\begin{array}{c}\text { desc. entre } \\
80 \% \text { e } 100 \% \\
\text { das escolas } \\
\text { estaduais }\end{array}$ \\
\hline 1 ano de descentralização & 0,034 & 0,034 & $0,113 * * *$ & $0,175^{* * *}$ & 0,004 \\
\hline 2 anos de descentralização & $\begin{array}{c}0,020 \\
(0,033)\end{array}$ & $\begin{array}{c}0,030 \\
(0,030)\end{array}$ & $\begin{array}{c}0,099 * * \\
(0,048)\end{array}$ & $\begin{array}{c}0,160 * * * \\
(0,057)\end{array}$ & $\begin{array}{c}0,005 \\
(0,040)\end{array}$ \\
\hline 3 anos de descentralização & $\begin{array}{c}0,003 \\
(0,041)\end{array}$ & $\begin{array}{c}0,022 \\
(0,037)\end{array}$ & $\begin{array}{c}0,076 \\
(0,057)\end{array}$ & $\begin{array}{c}0,153^{* *} \\
(0,065)\end{array}$ & $\begin{array}{l}-0,004 \\
(0,050)\end{array}$ \\
\hline 4 anos de descentralização & $\begin{array}{l}-0,010 \\
(0,050)\end{array}$ & $\begin{array}{c}0,019 \\
(0,043)\end{array}$ & $\begin{array}{c}0,054 \\
(0,068)\end{array}$ & $\begin{array}{l}0,130^{*} \\
(0,077)\end{array}$ & $\begin{array}{c}0,017 \\
(0,064)\end{array}$ \\
\hline 5 anos de descentralização & $\begin{array}{l}-0,014 \\
(0,061)\end{array}$ & $\begin{array}{c}0,013 \\
(0,051)\end{array}$ & $\begin{array}{c}0,027 \\
(0,082)\end{array}$ & $\begin{array}{c}0,137 \\
(0,091)\end{array}$ & $\begin{array}{c}0,026 \\
(0,081)\end{array}$ \\
\hline Dependência fiscal dos municípios & $\begin{array}{l}-0,043 \\
(0,041)\end{array}$ & $\begin{array}{c}0,013 \\
(0,025)\end{array}$ & $\begin{array}{l}-0,011 \\
(0,025)\end{array}$ & $\begin{array}{l}-0,014 \\
(0,027)\end{array}$ & $\begin{array}{l}-0,021 \\
(0,028)\end{array}$ \\
\hline Dependência fiscal dos estados & $\begin{array}{c}0,014 \\
(0,023)\end{array}$ & $\begin{array}{c}0,039 \\
(0,029)\end{array}$ & $\begin{array}{c}0,143 * * * \\
(0,045)\end{array}$ & $\begin{array}{c}0,209^{* * * *} \\
(0,060)\end{array}$ & $\begin{array}{c}0,001 \\
(0,054)\end{array}$ \\
\hline Gasto por aluno dos municípios & $\begin{array}{l}-0,000 \\
(0,000)\end{array}$ & $\begin{array}{l}-0,000 \\
(0,000)\end{array}$ & $\begin{array}{l}-0,000 \\
(0,000)\end{array}$ & $\begin{array}{c}0,000 \\
(0,000)\end{array}$ & $\begin{array}{l}-0,000 \\
(0,000)\end{array}$ \\
\hline Gasto por aluno dos estados & $\begin{array}{c}0,000^{* * *} * \\
(0,000)\end{array}$ & $\begin{array}{c}0,000 \\
(0,000)\end{array}$ & $\begin{array}{c}0,000 * * * \\
(0,000)\end{array}$ & $\begin{array}{c}0,000^{* * * *} \\
(0,000)\end{array}$ & $\begin{array}{c}0,000 \\
(0,000)\end{array}$ \\
\hline Município beneficiário de recursos do FUNDEF & $\begin{array}{c}0,010 \\
(0,007)\end{array}$ & $\begin{array}{c}-0,015^{* *} \\
(0,006)\end{array}$ & $\begin{array}{l}-0,012 \\
(0,007)\end{array}$ & $\begin{array}{c}-0,023^{* * *} \\
(0,008)\end{array}$ & $\begin{array}{l}-0,009 \\
(0,006)\end{array}$ \\
\hline Estado beneficiário de recursos do FUNDEF & $\begin{array}{c}-0,012 * * * \\
(0,004)\end{array}$ & $\begin{array}{l}-0,002 \\
(0,006)\end{array}$ & $\begin{array}{c}-0,029 * * * \\
(0,008)\end{array}$ & $\begin{array}{l}-0,024^{*} \\
(0,013)\end{array}$ & $\begin{array}{c}-0,033^{* *} * \\
(0,014)\end{array}$ \\
\hline Controles & Sim & Sim & Sim & Sim & Sim \\
\hline Dummies de ano & Sim & Sim & Sim & Sim & Sim \\
\hline $\mathrm{R}$ quadrado ajustado & 0,031 & 0,028 & 0,032 & 0,035 & 0,036 \\
\hline Observações & 14.519 & 8.700 & 9.586 & 6.025 & 3.978 \\
\hline
\end{tabular}

***significante a $1 \%, * *$ significante a $5 \%$ e *significante a $10 \%$ 
Tabela 27: Impactos da descentralização nas taxas de aprovação por faixas de descentralização $\left(1^{a}\right.$ a $4^{a}$ série)

\begin{tabular}{|c|c|c|c|c|c|}
\hline & $\begin{array}{c}\text { desc. menos } \\
\text { de } 20 \% \\
\text { das escolas } \\
\text { estaduais }\end{array}$ & $\begin{array}{l}\text { Municíp } \\
\text { desc. entre } \\
20 \% \text { e } 40 \% \\
\text { das escolas } \\
\text { estaduais }\end{array}$ & $\begin{array}{c}\text { os que descen } \\
\text { desc. entre } \\
40 \% \text { e } 60 \% \\
\text { das escolas } \\
\text { estaduais }\end{array}$ & $\begin{array}{l}\text { alizaram: } \\
\text { desc. entre } \\
60 \% \text { e } 80 \% \\
\text { das escolas } \\
\text { estaduais }\end{array}$ & $\begin{array}{c}\text { desc. entre } \\
80 \% \text { e } 100 \% \\
\text { das escolas } \\
\text { estaduais }\end{array}$ \\
\hline 1 ano de descentralização & $\begin{array}{l}-0,014 \\
(0,036)\end{array}$ & $\begin{array}{c}0,003 \\
(0,039)\end{array}$ & $\begin{array}{c}-0,166^{* * * *} \\
(0,043)\end{array}$ & $\begin{array}{c}-0,118 * * \\
(0,052)\end{array}$ & $\begin{array}{l}-0,039 \\
(0,055)\end{array}$ \\
\hline 2 anos de descentralização & $\begin{array}{c}0,010 \\
(0,049)\end{array}$ & $\begin{array}{c}0,036 \\
(0,050)\end{array}$ & $\begin{array}{c}-0,164 * * * \\
(0,051)\end{array}$ & $\begin{array}{c}-0,122 * * \\
(0,062)\end{array}$ & $\begin{array}{l}-0,054 \\
(0,053)\end{array}$ \\
\hline 3 anos de descentralização & $\begin{array}{c}0,067 \\
(0,059)\end{array}$ & $\begin{array}{c}0,081 \\
(0,062)\end{array}$ & $\begin{array}{c}-0,110^{*} \\
(0,062)\end{array}$ & $\begin{array}{l}-0,094 \\
(0,074)\end{array}$ & $\begin{array}{l}-0,031 \\
(0,063)\end{array}$ \\
\hline 4 anos de descentralização & $\begin{array}{c}0,116 \\
(0,074)\end{array}$ & $\begin{array}{l}0,124^{*} \\
(0,075)\end{array}$ & $\begin{array}{l}-0,061 \\
(0,074)\end{array}$ & $\begin{array}{l}-0,065 \\
(0,091)\end{array}$ & $\begin{array}{l}-0,040 \\
(0,080)\end{array}$ \\
\hline 5 anos de descentralização & $\begin{array}{l}0,153^{*} \\
(0,089)\end{array}$ & $\begin{array}{c}0,180^{* *} \\
(0,089)\end{array}$ & $\begin{array}{c}-0,002 \\
(0,089)\end{array}$ & $\begin{array}{l}-0,050 \\
(0,109)\end{array}$ & $\begin{array}{l}-0,038 \\
(0,102)\end{array}$ \\
\hline Dependência fiscal dos municípios & $\begin{array}{c}0,071 \\
(0,066)\end{array}$ & $\begin{array}{l}-0,003 \\
(0,033)\end{array}$ & $\begin{array}{c}0,108 * * * \\
(0,031)\end{array}$ & $\begin{array}{c}0,023 \\
(0,034)\end{array}$ & $\begin{array}{c}0,034 \\
(0,036)\end{array}$ \\
\hline Dependência fiscal dos estados & $\begin{array}{l}-0,014 \\
(0,032)\end{array}$ & $\begin{array}{c}0,010 \\
(0,041)\end{array}$ & $\begin{array}{c}-0,147 * * * \\
(0,048)\end{array}$ & $\begin{array}{c}-0,155 * * \\
(0,069)\end{array}$ & $\begin{array}{l}-0,003 \\
(0,081)\end{array}$ \\
\hline Gasto por aluno dos municípios & $\begin{array}{c}0,000 \\
(0,000)\end{array}$ & $\begin{array}{l}-0,000 \\
(0,000)\end{array}$ & $\begin{array}{c}0,000 \\
(0,000)\end{array}$ & $\begin{array}{l}-0,000 \\
(0,000)\end{array}$ & $\begin{array}{c}0,000 \\
(0,000)\end{array}$ \\
\hline Gasto por aluno dos estados & $\begin{array}{l}-0,000 \\
(0,000)\end{array}$ & $\begin{array}{l}-0,000 \\
(0,000)\end{array}$ & $\begin{array}{c}-0,000^{* * * *} \\
(0,000)\end{array}$ & $\begin{array}{l}-0,000^{*} \\
(0,000)\end{array}$ & $\begin{array}{l}-0,000 \\
(0,000)\end{array}$ \\
\hline Município beneficiário de recursos do FUNDEF & $\begin{array}{c}-0,028^{*} \\
(0,015)\end{array}$ & $\begin{array}{l}0,016^{*} \\
(0,009)\end{array}$ & $\begin{array}{c}0,021 * * \\
(0,009)\end{array}$ & $\begin{array}{c}0,047 * * * \\
(0,010)\end{array}$ & $\begin{array}{l}0,018^{*} \\
(0,010)\end{array}$ \\
\hline Estado beneficiário de recursos do FUNDEF & $\begin{array}{c}0,017 * * * \\
(0,005)\end{array}$ & $\begin{array}{c}0,008 \\
(0,007)\end{array}$ & $\begin{array}{c}0,026 * * * \\
(0,008)\end{array}$ & $\begin{array}{c}0,009 \\
(0,014)\end{array}$ & $\begin{array}{c}0,034 \\
(0,021)\end{array}$ \\
\hline Controles & Sim & Sim & Sim & Sim & Sim \\
\hline Dummies de ano & Sim & Sim & Sim & Sim & Sim \\
\hline $\mathrm{R}$ quadrado ajustado & 0,022 & 0,021 & 0,035 & 0,040 & 0,019 \\
\hline Observações & 14.519 & 8.700 & 9.586 & 6.025 & 3.978 \\
\hline
\end{tabular}

***significante a $1 \%, * *$ significante a $5 \%$ e *significante a $10 \%$ 
Tabela 28: Impactos da descentralização nas taxas de reprovação por faixas de descentralização ( $1^{a}$ a $4^{a}$ série)

\begin{tabular}{|c|c|c|c|c|c|}
\hline & $\begin{array}{c}\text { desc. menos } \\
\text { de } 20 \% \\
\text { das escolas } \\
\text { estaduais }\end{array}$ & $\begin{array}{l}\text { Municíp } \\
\text { desc. entre } \\
20 \% \text { e } 40 \% \\
\text { das escolas } \\
\text { estaduais }\end{array}$ & $\begin{array}{c}\text { os que descen } \\
\text { desc. entre } \\
40 \% \text { e } 60 \% \\
\text { das escolas } \\
\text { estaduais }\end{array}$ & $\begin{array}{l}\text { alizaram: } \\
\text { desc. entre } \\
60 \% \text { e } 80 \% \\
\text { das escolas } \\
\text { estaduais }\end{array}$ & $\begin{array}{c}\text { desc. entre } \\
80 \% \text { e } 100 \% \\
\text { das escolas } \\
\text { estaduais }\end{array}$ \\
\hline 1 ano de descentralização & $\begin{array}{l}-0,020 \\
(0,027)\end{array}$ & $\begin{array}{l}-0,037 \\
(0,031)\end{array}$ & $\begin{array}{l}0,053^{*} \\
(0,031)\end{array}$ & $\begin{array}{c}-0,057^{*} \\
(0,034)\end{array}$ & $\begin{array}{c}0,035 \\
(0,044)\end{array}$ \\
\hline 2 anos de descentralização & $\begin{array}{l}-0,030 \\
(0,036)\end{array}$ & $\begin{array}{c}-0,066^{*} \\
(0,039)\end{array}$ & $\begin{array}{l}0,065^{*} \\
(0,037)\end{array}$ & $\begin{array}{l}-0,038 \\
(0,039)\end{array}$ & $\begin{array}{c}0,050 \\
(0,040)\end{array}$ \\
\hline 3 anos de descentralização & $\begin{array}{l}-0,071 \\
(0,044)\end{array}$ & $\begin{array}{c}-0,102 * * \\
(0,048)\end{array}$ & $\begin{array}{c}0,033 \\
(0,042)\end{array}$ & $\begin{array}{l}-0,059 \\
(0,045)\end{array}$ & $\begin{array}{c}0,035 \\
(0,042)\end{array}$ \\
\hline 4 anos de descentralização & $\begin{array}{l}-0,106^{*} \\
(0,055)\end{array}$ & $\begin{array}{c}-0,143^{* *} \\
(0,058)\end{array}$ & $\begin{array}{c}0,007 \\
(0,049)\end{array}$ & $\begin{array}{l}-0,065 \\
(0,056)\end{array}$ & $\begin{array}{c}0,023 \\
(0,051)\end{array}$ \\
\hline 5 anos de descentralização & $\begin{array}{c}-0,138^{* *} \\
(0,066)\end{array}$ & $\begin{array}{c}-0,193 * * * \\
(0,069)\end{array}$ & $\begin{array}{l}-0,025 \\
(0,058)\end{array}$ & $\begin{array}{l}-0,087 \\
(0,067)\end{array}$ & $\begin{array}{c}0,012 \\
(0,063)\end{array}$ \\
\hline Dependência fiscal dos municípios & $\begin{array}{l}-0,028 \\
(0,049)\end{array}$ & $\begin{array}{l}-0,010 \\
(0,027)\end{array}$ & $\begin{array}{c}-0,097 * * * \\
(0,025)\end{array}$ & $\begin{array}{l}-0,009 \\
(0,025)\end{array}$ & $\begin{array}{l}-0,012 \\
(0,030)\end{array}$ \\
\hline Dependência fiscal dos estados & $\begin{array}{l}-0,000 \\
(0,024)\end{array}$ & $\begin{array}{l}-0,048 \\
(0,033)\end{array}$ & $\begin{array}{c}0,004 \\
(0,036)\end{array}$ & $\begin{array}{l}-0,054 \\
(0,048)\end{array}$ & $\begin{array}{c}0,002 \\
(0,061)\end{array}$ \\
\hline Gasto por aluno dos municípios & $\begin{array}{c}0,000 \\
(0,000)\end{array}$ & $\begin{array}{c}0,000 \\
(0,000)\end{array}$ & $\begin{array}{l}-0,000 \\
(0,000)\end{array}$ & $\begin{array}{c}0,000 \\
(0,000)\end{array}$ & $\begin{array}{c}0,000 \\
(0,000)\end{array}$ \\
\hline Gasto por aluno dos estados & $\begin{array}{c}-0,000 \\
(0,000)\end{array}$ & $\begin{array}{c}0,000 \\
(0,000)\end{array}$ & $\begin{array}{c}0,000 \\
(0,000)\end{array}$ & $\begin{array}{c}-0,000 * * * * \\
(0,000)\end{array}$ & $\begin{array}{l}-0,000 \\
(0,000)\end{array}$ \\
\hline Município beneficiário de recursos do FUNDEF & $\begin{array}{c}0,018 \\
(0,014)\end{array}$ & $\begin{array}{l}-0,001 \\
(0,008)\end{array}$ & $\begin{array}{l}-0,009 \\
(0,007)\end{array}$ & $\begin{array}{c}-0,024 * * * \\
(0,008)\end{array}$ & $\begin{array}{l}-0,008 \\
(0,008)\end{array}$ \\
\hline Estado beneficiário de recursos do FUNDEF & $\begin{array}{l}-0,006^{*} \\
(0,003)\end{array}$ & $\begin{array}{l}-0,005 \\
(0,004)\end{array}$ & $\begin{array}{c}0,003 \\
(0,007)\end{array}$ & $\begin{array}{c}0,016 \\
(0,010)\end{array}$ & $\begin{array}{l}-0,001 \\
(0,016)\end{array}$ \\
\hline Controles & Sim & Sim & Sim & Sim & Sim \\
\hline Dummies de ano & Sim & Sim & Sim & Sim & Sim \\
\hline $\mathrm{R}$ quadrado ajustado & 0,007 & 0,012 & 0,017 & 0,023 & 0,013 \\
\hline Observações & 14.519 & 8.700 & 9.586 & 6.025 & 3.978 \\
\hline
\end{tabular}

***significante a $1 \%, * *$ significante a $5 \%$ e *significante a $10 \%$ 
Tabela 29: Impactos da descentralização nas taxas de distorção idade-série por faixas de descentralização $\left(1^{a}\right.$ a $4^{a}$ série $)$

\begin{tabular}{|c|c|c|c|c|c|}
\hline & $\begin{array}{c}\text { desc. menos } \\
\text { de } 20 \% \\
\text { das escolas } \\
\text { estaduais }\end{array}$ & $\begin{array}{l}\text { Municíp } \\
\text { desc. entre } \\
20 \% \text { e } 40 \% \\
\text { das escolas } \\
\text { estaduais }\end{array}$ & $\begin{array}{c}\text { os que descen } \\
\text { desc. entre } \\
40 \% \text { e } 60 \% \\
\text { das escolas } \\
\text { estaduais }\end{array}$ & $\begin{array}{l}\text { alizaram: } \\
\text { desc. entre } \\
60 \% \text { e } 80 \% \\
\text { das escolas } \\
\text { estaduais }\end{array}$ & $\begin{array}{c}\text { desc. entre } \\
80 \% \text { e } 100 \% \\
\text { das escolas } \\
\text { estaduais }\end{array}$ \\
\hline 1 ano de descentralização & $\begin{array}{l}0,056^{*} \\
(0,030)\end{array}$ & $\begin{array}{c}0,113 * * * \\
(0,038)\end{array}$ & $\begin{array}{l}-0,027 \\
(0,035)\end{array}$ & $\begin{array}{c}0,025 \\
(0,036)\end{array}$ & $\begin{array}{l}-0,089^{*} \\
(0,053)\end{array}$ \\
\hline 2 anos de descentralização & $\begin{array}{c}0,056 \\
(0,037)\end{array}$ & $\begin{array}{c}0,134 * * * \\
(0,051)\end{array}$ & $\begin{array}{l}-0,043 \\
(0,043)\end{array}$ & $\begin{array}{c}0,025 \\
(0,040)\end{array}$ & $\begin{array}{l}-0,099^{*} \\
(0,059)\end{array}$ \\
\hline 3 anos de descentralização & $\begin{array}{c}0,038 \\
(0,044)\end{array}$ & $\begin{array}{c}0,133^{* *} \\
(0,065)\end{array}$ & $\begin{array}{l}-0,052 \\
(0,052)\end{array}$ & $\begin{array}{c}0,021 \\
(0,046)\end{array}$ & $\begin{array}{l}-0,099 \\
(0,072)\end{array}$ \\
\hline 4 anos de descentralização & $\begin{array}{c}0,016 \\
(0,054)\end{array}$ & $\begin{array}{l}0,141^{*} \\
(0,081)\end{array}$ & $\begin{array}{l}-0,077 \\
(0,063)\end{array}$ & $\begin{array}{c}0,010 \\
(0,056)\end{array}$ & $\begin{array}{l}-0,142 \\
(0,094)\end{array}$ \\
\hline 5 anos de descentralização & $\begin{array}{c}0,018 \\
(0,066)\end{array}$ & $\begin{array}{c}0,141 \\
(0,099)\end{array}$ & $\begin{array}{l}-0,121 \\
(0,075)\end{array}$ & $\begin{array}{l}-0,020 \\
(0,068)\end{array}$ & $\begin{array}{l}-0,171 \\
(0,122)\end{array}$ \\
\hline Dependência fiscal dos municípios & $\begin{array}{l}-0,011 \\
(0,042)\end{array}$ & $\begin{array}{c}-0,120 * * * \\
(0,032)\end{array}$ & $\begin{array}{c}0,001 \\
(0,025)\end{array}$ & $\begin{array}{l}-0,045^{*} \\
(0,027)\end{array}$ & $\begin{array}{c}0,012 \\
(0,034)\end{array}$ \\
\hline Dependência fiscal dos estados & $\begin{array}{c}0,068 * * * \\
(0,026)\end{array}$ & $\begin{array}{c}0,090^{* *} \\
(0,041)\end{array}$ & $\begin{array}{c}0,022 \\
(0,045)\end{array}$ & $\begin{array}{c}0,025 \\
(0,053)\end{array}$ & $\begin{array}{l}-0,130^{*} \\
(0,076)\end{array}$ \\
\hline Gasto por aluno dos municípios & $\begin{array}{c}0,000 \\
(0,000)\end{array}$ & $\begin{array}{c}-0,000 * * \\
(0,000)\end{array}$ & $\begin{array}{c}0,000 \\
(0,000)\end{array}$ & $\begin{array}{l}-0,000 \\
(0,000)\end{array}$ & $\begin{array}{c}-0,000 * * \\
(0,000)\end{array}$ \\
\hline Gasto por aluno dos estados & $\begin{array}{c}0,000^{* *} \\
(0,000)\end{array}$ & $\begin{array}{c}0,000 \\
(0,000)\end{array}$ & $\begin{array}{l}-0,000 \\
(0,000)\end{array}$ & $\begin{array}{c}0,000 \\
(0,000)\end{array}$ & $\begin{array}{l}-0,000^{*} \\
(0,000)\end{array}$ \\
\hline Município beneficiário de recursos do FUNDEF & $\begin{array}{l}-0,011 \\
(0,013)\end{array}$ & $\begin{array}{l}0,015^{*} \\
(0,009)\end{array}$ & $\begin{array}{c}0,002 \\
(0,008)\end{array}$ & $\begin{array}{l}-0,001 \\
(0,009)\end{array}$ & $\begin{array}{c}-0,016^{*} \\
(0,008)\end{array}$ \\
\hline Estado beneficiário de recursos do FUNDEF & $\begin{array}{c}-0,012 * * * \\
(0,004)\end{array}$ & $\begin{array}{c}0,005 \\
(0,007)\end{array}$ & $\begin{array}{c}0,001 \\
(0,007)\end{array}$ & $\begin{array}{c}0,004 \\
(0,011)\end{array}$ & $\begin{array}{c}0,014 \\
(0,014)\end{array}$ \\
\hline Controles & Sim & Sim & Sim & Sim & Sim \\
\hline Dummies de ano & Sim & Sim & Sim & Sim & Sim \\
\hline $\mathrm{R}$ quadrado ajustado & 0,074 & 0,080 & 0,073 & 0,066 & 0,093 \\
\hline Observações & 12.655 & 7.692 & 8.570 & 5.302 & 3.587 \\
\hline
\end{tabular}

***significante a $1 \%, * *$ significante a $5 \%$ e *significante a $10 \%$ 